Studia Judaica 24 (2021), nr 1 (47), s. 41-97

doi:10.4467/24500100STJ.21.003.14605

Andrzej Trzciński iD https://orcid.org/0000-0001-6378-7988

\title{
Słowo i obraz - teksty i związane z nimi motywy ikoniczne na nagrobkach kobiet na cmentarzach żydowskich na historycznych obszarach Rzeczypospolitej
}

\author{
WORD AND IMAGE: TEXTS AND RELATED ICONIC MOTIFS \\ ON WOMEN'S GRAVESTONES IN JEWISH CEMETERIES \\ IN THE HISTORICAL AREAS OF THE REPUBLIC OF POLAND
}

\begin{abstract}
The research material in the article covers the period from the earliest gravestones from the fourteenth century to contemporary ones of the twenty-first century. Among iconic motifs taken into account are those which are specific for women's gravestones, and from texts in inscriptions-those corresponding to artistic motifs.

The aims of this study are the following: to distinguish thematic groups, determine the range of iconic motifs used and the chronology and frequency of their occurrence, as well as to juxtapose them with normative content from religious writings of Judaism and with rites and customs.

The following conclusions emerge from the research: In the early period (until the fourth quarter of the eighteenth century), there was no differentiation on tombstones between separate motifs ascribed to men (except for the Kohanim and Levites) and separate motifs ascribed to women. Among the common motifs, the bird motif dominated on women's gravestones, while the crown motif acquired its specific character. In the fourth quarter of the eighteenth century, the motif of a candlestick appeared on women's gravestones; it spread very quickly and became a visual identification feature. In the nineteenth century, with the introduction of vanitas motifs on gravestones, they began to be used on women's gravestones. The connection of motifs with the names of the deceased is also noticeable (e.g. Feigl-bird, Rachel-fairy, Royza-rose, or scenes related to biblical namesakes). The contents of women's epitaphs presented as praise or description of virtues largely concern traditional female duties toward the home, husband, and children. Women's gravestones contain no attributes or references to the
\end{abstract}


study of Torah and scholarship, or else to activities in the public spherefessions, both religious and later secular-which obviously results from the position and role of women in the patriarchal community. Such information does not appear until the interwar period on the tombstones of women from families assimilated into the surrounding culture which is also evidenced by non-traditional tombstone forms and inscriptions in non-Jewish languages.

Keywords: Jewish woman, Jewish tombstones, sepulchral symbolism, iconology.

Słowa kluczowe: kobieta żydowska, nagrobki żydowskie, symbolika sepulkralna, ikonologia.

\section{Wstęp}

Artykuł stanowi próbę całościowego ujęcia tematu, który nie był dotychczas opracowany kompleksowo. Poszczególne wątki pojawiały się w literaturze przedmiotu tylko na tle szerszych ujęć ${ }^{1}$. Materiał badawczy pochodzi $\mathrm{z}$ inwentaryzacji własnych autora oraz $\mathrm{z}$ dokumentacji fotograficznej dostępnej w publikacjach. Obejmuje - na przyjętym w tytule tekstu obszarze - okres od najwcześniejszych nagrobków z wieku XIV po współczesne z XXI. Spośród motywów ikonicznych wzięte zostały pod uwagę te, które są specyficzne dla nagrobków kobiet, z tekstów w inskrypcjach zaś te korespondujące z motywami plastycznymi, omówienie bowiem wszystkich treści i motywów występujących na nagrobkach kobiet to obszerne, osobne zagadnienie (częściowo już opracowane w monografiach poszczególnych cmentarzy $^{2}$ ). Cele niniejszego opracowania są następujące: wyodrębnienie

${ }^{1}$ Arthur Levy, Jüdische Grabmalkunst in Osteuropa: Eine Sammlung, Berlin 1924; Monika Krajewska, Cmentarze żydowskie w Polsce: nagrobki i epitafia, „Polska Sztuka Ludowa” 43 (1989), nr 1-2, s. 27-44; taż, Symbolika płaskorzeźb na cmentarzach żydowskich w Polsce, tamże, s. 45-59; taż, A Tribe of Stones: Jewish Cemeteries in Poland, wstęp Rafael Scharf, Warsaw 1993; Andrzej Trzciński, Symbole i obrazy. Treści symboliczne przedstawień na nagrobkach żydowskich w Polsce, Lublin 1997.

${ }^{2}$ M.in.: Leszek Hońdo, Stary żydowski cmentarz w Krakowie. Historia cmentarza. Analiza hebrajskich inskrypcji, Kraków 1999, rozdz. 4; Jan Paweł Woronczak, Cmentarz żydowski w Kromołowie jako tekst kultury, Wrocław 1999 (mps rozprawy doktorskiej pod kierunkiem prof. Jacka Kolbuszewskiego, Uniwersytet Wrocławski), rozdz. 5; Andrzej Trzciński, Jerzy Sobota, Cmentarze żydowskie w Międzyrzecu Podlaskim, Lublin 2009, rozdz. 4.4 i 7; Andrzej Trzciński, Cmentarz żydowski w Lesku. Część II - wiek XVIII, Lublin 2020, rozdz. 3 i 5; Aneta Krzywicka, Andrzej Trzciński, Technologiczne i formalne cechy nagrobków, [w:] Cmentarze żydowskie w Sandomierzu, red. Piotr Sławiński, Sandomierz 2011, s. 105 i n.; Andrzej Trzciński, Aspekty filologiczne inskrypcji, [w:] tamże, s. 121 i n.; tenże, Świadkiem jest ta stela. Stary cmentarz żydowski w Lublinie, Lublin 2017, rozdz. 6.4 i 8; tenże, This Very Stone Shall Be a Witness: The Jewish Cemetery in Wielkie Oczy, tłum. Marcin Garbowski, New York 2019, rozdz. 3.4 i 4. 
grup tematycznych, ustalenie zasobu stosowanych motywów ikonicznych oraz chronologii i częstości ich występowania, zestawienie z treściami normatywnymi z pism religijnych judaizmu oraz z obrzędami i zwyczajami. Do tekstów źródłowych judaizmu (Biblia hebrajska i literatura pobiblijna) korzystano z edycji elektronicznej Sefaria ${ }^{3}$.

\section{Okres wczesny - próby różnicowania}

W okresie średniowiecza i do początku XVI w. na aszkenazyjskim obszarze geokulturowym motywy figuratywne na nagrobkach żydowskich stosowano sporadycznie $^{4}$. Inskrypcja obejmowała całe lico steli, a dodatkowym składnikiem bywało jej obramowanie elementami architektonicznymi. Taki stan nie należał do rzadkości jeszcze w ciągu XVII w. We wczesnym okresie wprowadzania na macewy motywów ikonicznych nie istniało zróżnicowanie na takie, które umieszczano na nagrobkach kobiet, i takie, które zdobiły nagrobki mężczyzn (oprócz tych należnych tylko potomkom kohenów i lewitów). Do najpopularniejszych powszechnie stosowanych należały rozmaite motywy roślinne reprezentujące drzewo życia w różnych warstwach znaczeniowych, czworonożne zwierzęta i istoty mieszane (głównie lew, jeleń, jednorożec, gryf), ptaki oraz korona. Te dwa ostatnie z wymienionych motywów uzyskały w XVIII w. pewną specyfikę na nagrobkach kobiet.

\subsection{Ptak}

Ptak w sensie ogólnym ma liczne odniesienia w literaturze judaizmu i ludowych wierzeniach. Jest symbolem o dużej pojemności znaczeniowej - reprezentuje zarówno lud Izraela, jak i pojedynczego człowieka,

${ }_{3}^{3}$ Sefaria: A Living Library of Jewish Texts, https://www.sefaria.org/?home. Przekład Biblii na podstawie wydania Biblia to jest Pismo Święte Starego i Nowego Testamentu, nowy przekład z języków hebrajskiego i greckiego, Brytyjskie i Zagraniczne Towarzystwo Biblijne, Warszawa 1979, z ewentualną korektą autora niniejszego opracowania, gdy przekład okazał się nieodpowiedni. Cytaty z innych tekstów źródłowych lub opracowań tłumaczone z języków obcych na język polski podane są w przekładzie autora, o ile nie wskazano innego thumacza.

${ }^{4}$ Znane są takie wyjątkowe przykłady z terenów Niemiec (Wormacja XIII - początek XV w., Würzburg XIII w., Spira XIV w.) i Czech (Praga XIV w.). Są to schematyczne przedstawienia słońca i księżyca (odnoszące się do Tory jako boskiego Prawa, boskiego światła w wymiarze kosmicznym, niebiańskim), lilii i rozet kwiatowych (głównie na nagrobkach panien i młodzieńców), ptaków. Nie uwidocznia się zróżnicowanie pod względem płci. Szerzej zob.: Trzciński, Symbole i obrazy..., rozdz. V.B.; Michael Brocke, The Lilies of Worms, „Zutot” 8 (2011), s. 3-13 (za zwrócenie uwagi na ten artykuł dziękuję Leszkowi Hońdzie). Dokumentacja z Wormacji dostępna w bazie Epidat, http://www.steinheiminstitut.de/cgi-bin/epidat. 
a zwłaszcza jego duszę. W tekstach desygnatem jest zwykle ptak w znaczeniu ogólnym (hebr. cipor ${ }^{5}$ ), niekiedy konkretnie gołąb lub turkawka (hebr. jona lub tor). Przyjrzyjmy się wybranym przykładom tej tradycji. Figura ptaka jako ludu Izraela funkcjonuje w Biblii hebrajskiej (Iz 31,5; Oz 11,11), w apokryfach starotestamentowych (IV Ezd 5,23-26), w Talmudzie - zwłaszcza partiach hagadycznych, oraz w zbiorach midraszy ${ }^{6}$. Ptak symbolizuje też pojedynczego człowieka (w tym rodzica lub dziecko), a najczęściej jego duszę, począwszy od kanonu Biblii hebrajskiej (Ps 74,19; 102,8; 124,7; Prz 27,8) i jej apokryfów (III Baruch 10,1-5), poprzez Talmud (TB, Sanhedryn 91a i b; Pesachim 49a), midrasze ${ }^{7}$ i Zohar (np. 2,64a,25), po wierzenia ludowe ${ }^{8}$. Stąd obecność motywu ptaka na nagrobkach - jako reprezentanta osoby żywej lub zmarłej - jest oczywista ${ }^{9}$.

Na omawianym obszarze przed XVIII w. motyw ptaka występuje na macewach sporadycznie ${ }^{10}$ (np. pojedyncze małe ptaki: Rachel(?) córka Judy, żona Natana, zm. 1580 lub 1597, Kraków - il. 1; Awraham Josef zwany Fajgelz ${ }^{11}$ syn Dana, zm. 1601, Kraków), następnie już często, przy czym dominuje na nagrobkach kobiet (choć lokalnie stosowany jest w analogicznych kompozycjach jednocześnie na nagrobkach mężczyzn). Te kompozycje to najczęściej dwa ptaki pośród wici roślinnej (il. 23) lub po bokach (w układzie antytetycznym) - różnie ujmowanego - drzewa życia (towarzyszą im nierzadko inne motywy - zwykle zwierzęta, korona), albo pojedynczy ptak (w tym z ulistnioną gałązką w dziobie). Od czasu wprowadzenia na nagrobki kobiet motywu lichtarza (schyłek XVIII w.) jest on często adorowany przez parę ptaków (il. 7, 14, 22, 51). Owe ptaki

${ }^{5}$ Hebrajski rzeczownik cipor w Biblii hebrajskiej ma rodzaj gramatyczny żeński, w literaturze rabinicznej - wspólny (we współczesnym hebrajskim już męski), w jidysz - fojgl ma rodzaj gramatyczny męski.

6 Talmud babiloński [dalej: TB], Berachot 53b; Sanhedryn 95a; Bawa kama 93a; Midrasz Raba do Pnp, 1:15:2; 4:1:1; 4:1:20; Midrasz Raba do Wj, 20:6; 40:4; Midrasz Lekach tow do $\mathrm{Wj}, 14: 30: 2$.

${ }^{7}$ Midrasz Raba do Wj, 20:6; Midrasz Lekach tow do Lm, 3:52:1.

${ }^{8}$ Levy, Jüdische Grabmalkunst..., s. 47.

${ }^{9}$ Przypomnijmy, że w judaizmie istnieje zakaz przedstawiania postaci ludzkiej, szczególnie w obszarze synagogi i cmentarza, stąd tak liczne motywy zastępcze ze świata flory i fauny. Pośród Żydów sefardyjskich zakaz ten bywał łamany od XVII w., pośród aszkenazyjskich - od XIX w. i tylko w kręgach postępowych.

${ }^{10}$ Spoza omawianego obszaru pojedyncze przypadki umieszczania motywu ptaka (w tym obok lilii) na nagrobkach młodzieńców i panien znane są z Wormacji z wieku XIII i pierwszej połowy XIV - zob. Brocke, The Lilies..., s. 6 i n.

${ }^{11}$ Fajgelz - tak w inskrypcji. Gramatyczna forma Fajgels w języku jidysz może oznaczać zarówno bycie synem Fajgli, jak i bycie mężem Fajgli. Może to być przezwisko dotyczące konkretnej osoby albo przydomek funkcjonujący przez kilka pokoleń. 
zwykle nie mają cech charakterystycznych. Tylko w realizacjach rzeźby kwalifikowanej - i raczej dopiero od XIX w. - nadawano ptakom cechy gatunku. Można wówczas zidentyfikować gołębia. Pojawiają się też ptaki mniej lub bardziej podobne do pelikana, nierzadko w otoczeniu piskląt, w specyficznej pozie pelikana karmiącego krwią z piersi swoje młode - jako wyraz matczynej troski (np. w Warszawie, Brodach, Satanowie - zob. il. 7), co niewątpliwie jest formalną kalką motywu z otoczenia chrześcijańskiego, lecz nasyconą treściami judaizmu ${ }^{12}$. Należy też wspomnieć, że w tych późniejszych realizacjach nierzadko odchodzono od statycznego, antytetycznego schematu i wprowadzano sceny o mniej lub bardziej narracyjnym charakterze ${ }^{13}$.

W odróżnieniu od małych ptaków, ukazywanych najczęściej, spotykamy na nagrobkach - od schyłku XVII w. - ptaka dużego o cechach orła (hebr. neszer). Jeszcze do około połowy XIX w. przedstawiany jest podobnie jak na synagogalnych polichromiach ściennych, na oprawach szaf na Torę, na sprzętach obrzędowych - według schematu heraldycznego - frontalnie, z rozpostartymi skrzydłami, nierzadko jako dwugłowy, niekiedy w koronie i z atrybutami świąt w szponach ${ }^{14}$. W kontekście synagogi ów orzeł reprezentuje Boga, co ewidentnie potwierdzają umieszczane przy nim inskrypcje ${ }^{15}$. Jednym z przymiotów Boga ukazanych poprzez figurę orła jest jego opieka nad ludem Izraela i pojedynczym człowiekiem (Wj 19,4; Pwt 32,11 i n.; Iz 40,31; licznie w psalmach, m.in. 17,8; 36,8; 57,2; 91,4, i literaturze pobiblijnej, np. TB, Sanhedryn 92b; Zohar 1:12b:6). Cechą

${ }^{12}$ Pelikan w takiej pozie występuje w polichromiach synagogalnych i na sprzętach obrzędowych. O „żydowskim” pelikanie zob. Rachel Wischnitzer-Bernstein, Symbole und Gestalten der jüdischen Kunst, Berlin 1935, s. 86-89.

${ }^{13}$ Ukażą to następne przykłady, niewymienione w tym punkcie.

14 Takie ujęcie orła kojarzy się z godłami państw ościennych, lecz ma tradycję jeszcze starożytną i jest tylko kalką kompozycyjną podobnych wzorów. Niektórzy autorzy widzą w takich przedstawieniach wpływ godeł państw zaborczych, lecz liczne przykłady od XVII w. przeczą takiej tezie.

${ }^{15}$ Orzeł heraldyczny (jedno- lub dwugłowy) występuje powszechnie na sprzętach ze sfery kultu i obrzędów. Jako reprezentacja Boga, szczególnie w zwieńczeniach obramowań szaf na Torę (najwcześniejsze znane z XVII w.) - w koronie królestwa lub koronie Tory, z insygniami w szponach (w kontekście judaizmu są to zwykle szofar, lulaw, etrog), opatrzony inskrypcjami (np. tetragram, formuła Sziwiti), m.in. w Drui, Olkiennikach, Płońsku, Szawkianach, Warce, Wizunach, Wołpie, Zelwie - zob. dokumentację fotograficzną: Maria i Kazimierz Piechotkowie, Bramy nieba. Bóżnice drewniane na ziemiach dawnej Rzeczypospolitej, Warszawa 1996, s. 87, 99-101, 348, 355; ci sami, Bramy nieba. Bóżnice murowane na ziemiach dawnej Rzeczypospolitej, Warszawa 1999, s. 303-305, 309, 396. Podobnie na ściennych polichromiach synagogalnych - zob. tamże, passim, oraz Andrzej Trzciński, Zachowane wystroje malarskie bóżnic w Polsce, „Studia Judaica” 4 (2001), nr 1-2 (7-8), s. 80-81. 
dystynktywną opieki są rozpostarte skrzydła ${ }^{16}$. Czy tak samo jest na nagrobkach? Nie da się tego stwierdzić na podstawie owych wczesnych hieratycznych przedstawień niemających odniesień w epitafiach. Lokalnie takie motywy bywają znacznie częściej na macewach kobiet (il. 4). Ten kierunek odczytania potwierdzają frazy w tekstach inskrypcji, a schronienie pod skrzydłami Szechiny (Obecności Bożej) jest nagrodą za pobożne życie, np.: „Dlatego znajdzie schronienie pod skrzydłami Szechiny” (Chaja córka Awrahama Aby, żona Naftalego Mehlguta, zm. 1866, Warszawa), „Bóg w swoim miłosierdziu okryje ją cieniem skrzydeł" (Riwka córka Naftalego Cwiego ha-kohena, żona Jaakowa Oliwensztejna, zm. 1868, Warszawa), „Skrzydła Szechiny splatają się nad nią” (Mircza córka Meira Dawida Mordechaja, zm. 1937, Radomsko). W pojedynczych przykładach z okresu międzywojennego inskrypcję - reprezentującą zmarłą - otacza/okrywa pełnoplastyczne przedstawienie skrzydeł, np. macewa Malki Malwiny z Hirszbergów Koenigstein (zm. 1927, Warszawa). Od XIX w., gdy orzeł ukazywany bywa bardziej realistycznie i w przedstawieniach samych w sobie bardziej narracyjnych lub nawet korespondujących z tekstem epitafium - wówczas jego odczytanie jest łatwiejsze. Oto orzeł, z rozpostartymi skrzydłami, trzymający w szponach węża na nagrobku Mirel córki Dawida Grosa, zm. 1884, Warszawa (il. 25). Interpretując to w skrócie - ów duży ptak, którego w tym przypadku można skojarzyć zarówno z Bogiem, jak i ze zmarłą - co w wielowarstwowości i wieloznaczności symboli nie jest niczym niezwykłym - reprezentuje siły dobra pokonujące zło. Podobnie na macewie Krejndel córki Cwiego (zm. 1920, Kielce) - siedzący na ściętej gałęzi orzeł trzyma w dziobie kiść winogron (il. 45). Scena opatrzona jest cytatem z Ps 80,15: „Spójrz z nieba i patrz. I ujmij się za tą winoroślą”17. Mimo ewidentnego przekazu: orzeł-Bóg Izraela, kiść winogron-Krejndel (a w szerszej perspektywie - lud Izraela jako winnica Pańska), nasuwa się druga warstwa odczytania - Krejndel niesie w drodze do niebios owoce swych dobrych uczynków. Trzeba przyznać, że w licznych realizacjach, zwłaszcza tych niedopowiedzianych formalnie, nastąpiło zespolenie treści kojarzonych z małym ptakiem oraz z orłem ${ }^{18}$. Nie da się stwierdzić, czy to zabiegi celowe, czy tylko nieporadność kamieniarzy.

${ }^{16}$ Ochrona w cieniu skrzydeł Boga pojawia się także w modlitwach, np. El male rachamim; Ma jakar; Haszkiwenu.

${ }^{17}$ Dalszy ciąg tej inwokacji do Boga brzmi: „I szczepem, który zasadziła twoja prawica, latoroślą, którą sobie wyhodowałeś".

${ }_{18}$ Zob. przykłady omówione dalej w punkcie 4.1: Chana córka Zeewa Wolfa, zm. 1862, Radomsko (il. 21); Lea córka Hilela, zm. 1888, Kazimierz Dolny (il. 26). 
Nasuwa się pytanie - dlaczego motyw ptaka dominuje na nagrobkach kobiet? Obecnie nie możemy już o to zapytać twórców przedstawień, choć wielu z nich prawdopodobnie odpowiedziałoby, że tak jest w zwyczaju. Wydaje się, że już w XVIII w. zaistniała potrzeba użycia motywu odróżniającego wizualnie nagrobki kobiet, choć wówczas nie czyniono tego wszędzie i konsekwentnie. Nie bez znaczenia może być to, że żona Mojżesza miała na imię Cipora - 'ptak' (Wj 2,21). W XIX w. motyw ptaka - oprócz motywu lichtarza, choć nie aż tak wyłącznie ${ }^{19}$ - stał się charakterystyczny dla nagrobków kobiet, a poprzez tę figurę przekazywano różnorodne treści specyficzne dla tradycyjnego obrazu kobiety, na co jeszcze zwrócona zostanie uwaga w dalszych punktach tematycznych.

\subsection{Korona}

W języku hebrajskim jest kilka wyrazów - keter, atara, nezer, zer, micnefet, liwjat-chen - których odpowiednikiem jest korona, wieniec, diadem, a ich użycie w różnych kontekstach ma wiele znaczeń, m.in. uwieńczenie, chwała, chluba, świetność, wspaniałość, pobożność, zasługa, nagroda ${ }^{20}$. W midraszach i opowieściach ludowych natrafiamy na metaforyczne projekcje mówiące o tym, że w przyszłym świecie sprawiedliwi zasiądą do uczty mesjańskiej w koronach na głowach ${ }^{21}$. Motyw korony, niekiedy wieńca, zauważalny jest na nagrobkach od początku XVII w. i przede wszystkim na macewach mężczyzn. Jest to związane z odniesieniami do frazy z Miszny (Pirke awot 4,17): „Są trzy korony: korona Tory, korona kapłaństwa i korona królestwa, lecz korona dobrego imienia jest ponad tamte". Korona symbolizująca Torę (keter Tora) na nagrobkach mężczyzn związana jest z nakazem studiowania przez nich Tory i innych pism religijnych ${ }^{22}$.

${ }^{19}$ Należy zaznaczyć, że jedynie lichtarz w znaczeniu 'lichtarza szabatowego’ był wyłączny dla nagrobków kobiet, natomiast jako sprzęt związany z symboliką światła, zwykle ukazany wraz ze świecą, funkcjonował także na nagrobkach mężczyzn.

${ }^{20}$ Obszerne opracowanie tej tematyki zob. Erwin Ramsey Goodenough, Jewish Symbols in the Greco-Roman Period, t. 7, New York 1958, części: Victory and Her Crown oraz The Crown (wbrew tytułowi praca ta obejmuje także po części okres nowożytny).

${ }^{21}$ Np.: TB, Berachot 17a; Szabat 88a; Regina Lilientalowa, Życie pozagrobowe $i$ świat przyszły w wyobrażeniu ludu żydowskiego, „Lud” 8 (1902), s. 352; Giuseppe Levi, Das Buch der jüdischen Weisheit: Parabeln, Legenden und Gedanken aus Talmud und Midrasch, Wien 1921, t. 2, s. 325; Jiři Langer, 9 bram do tajemnic chasydów, thum. Anna Godlewska, Kraków 1988, s. 66. W plastyce pozasepulkralnej niekiedy obrazowano to dosłownie, np. Biblia Ambrosiana, Niemcy, 1238 r., fol. 136.

${ }^{22}$ Iz 34,16; Mosze ben Majmon zwany Rambam, Miszne Tora, Talmud Tora 1,8; Tarjag micwot. 613 przykazań judaizmu, tłum. Ewa Gordon, Kraków 2000, przykazanie 419: micwat talmud Tora. 
W związku z tym jest też symbolem uczoności, mądrości (Prz 1,9; 4,9 - tu określona jako liwiat-chen i atara). Także keter kehuna należna jest tylko mężczyznom z pokoleń kapłańskich. Keter szem tow natomiast przysługuje także kobietom, lecz korona na macewach niewiast (il. 2, 10, 14, 50) - jak wskazują frazy w epitafiach - najczęściej określa kobietę jako koronę rodziny i koronę małżonka (w tych przypadkach atara; Prz 12,4), bywa też kojarzona z wersetem mówiącym o „mądrości kobiet” w kontekście domu (Prz 14,1). Oto przykłady korespondencji motywu korony z frazą w epitafium: „Niewiasta dzielna, korona swojego małżonka” (Prz 12,4; Jenta Pesa córka Meira, zm. 1830, Lublin - il. 10), „Chwała jej, wieniec i korona" (Basze córka Mordechaja Zeewa ha-kohena, zm. 1868, Szydłowiec), „Diadem naszej chluby” (Fradel córka Eliezera Jicchaka, zm. 1911, Opatów). Od słów keter i atara pochodzą imiesłowy muchteret i meuteret obydwa znaczą 'uwieńczona, ukoronowana' - a spotykamy je nierzadko od wczesnych epitafiów w takich zwrotach, jak: „uwieńczona cnotami i dobrymi uczynkami”, ,,ukoronowana czystością”. Przedstawienie korony na macewach kobiet jest znacznie rzadsze niż odniesienia do niej w epitafiach i nie uzyskało tak dużej popularności jak figura ptaka. Motyw ten zyskał jednak pewną kobiecą specyfikę w wyrażaniu treści laudacyjnych.

\section{Motywy związane z micwami}

Pośród 613 przykazań judaizmu (zakazów i nakazów), które kodyfikatorzy prawa religijnego wyodrębnili z tekstu Tory, niektóre dotyczą zwłaszcza lub wyłącznie kobiet (micwot naszim). Trzy z nich są szczególnie ważne, jak wynika choćby z bardzo częstego wzmiankowania o nich w epitafiach kobiet, i tak powszechnie znane, że od wieków zapisywane są w skrócie. Zwykle jest to fraza: במצות ח'ניה' היתה נזהרה , przykazań oddzielania ciasta, kąpieli rytualnej i zapalania świateł szabatu przestrzegała"23. Z kolejności liter w tym akronimie wyniknęło uosabiające określenie: „przykazania Chany”24.

${ }^{23}$ Według mędrców Miszny (Szabat 2,6) zaniedbywanie tych przykazań jest przyczyną śmierci kobiet podczas porodu. W przywoływanej już edycji Tarjag micwot... są to odpowiednio: micwat chala (micwa 385), micwat nida (micwa 181) i micwat kidusz szabat (micwa 31). W drugiej połowie XVI w. przykazania te omówił i uprzystępnił dla obszaru aszkenazyjskiego drukiem w języku jidysz Binjamin Aharon ben Awraham Slonik, Sejder micwes noszim; ejn szejn frauen bichlejn, Kraków 1577 (wydanie pierwsze, następnie wielokrotnie publikowane w różnych krajach).

${ }^{24}$ Redaktorzy epitafiów wykorzystywali to niekiedy jako koncept literacki w akrostychach na nagrobkach kobiet o tym imieniu, np. w Krzepicach: „Cha'n'a' stosownie do swego imienia sumiennie przykazań swych przestrzegała” (Chana córka Nachuma Meira, żona 
Lecz spośród owych micwot naszim tylko ta ostania ma odpowiedniki ikoniczne na nagrobkach, choć w ikonografii pozasepulkralnej przedstawienia dotyczące każdej z nich poświadczone są już w średniowiecznych iluminowanych manuskryptach, a następnie w drukach, zwłaszcza w licznych edycjach Sefer minhagim (Księga zwyczajów). Na macewach kobiet nierzadko umieszczano motywy związane z przykazaniami dobroczynności i modlitwy ${ }^{25}$, które dotyczą wszystkich, lecz z wyraźnymi cechami odróżniającymi na nagrobkach kobiet.

\subsection{Zapalanie świateł szabatowych}

Powinnością kobiety - pani domu - jest zapalenie na rozpoczęcie szabatu świec szabatowych (co najmniej dwu) i wypowiedzenie specjalnego błogosławieństwa: „Błogosławiony jesteś Ty, Ha-Szem, Bóg nasz, Król świata, który uświęcił nas swoimi przykazaniami i przykazał nam, by zapalać światło szabatu"26. Zwyczaj ten od wieków był znany i przedstawiany jest w plastyce pozasepulkralnej. Ikoniczne odniesienie do niego pojawiło się na nagrobkach dopiero w czwartej ćwierci XVIII w. ${ }^{27}$ Zasadniczym motywem jest lichtarz wieloramienny (niekiedy siedmioramienny ${ }^{28}$ ) lub kilka lichtarzy pojedynczych, nierzadko z ukazanymi świecami, z zaznaczonymi płomieniami lub tylko knotami. Lichtarzom często towarzyszą inne motywy (nierzadko ptaki) - zob. il. 7, 11, 14, 22, 46, 51. Od początku lichtarze przedstawiano jednocześnie w dwu konwencjach. Jedną wypada określić jako nierzeczywisty 'lichtarz-drzewo życia' lub 'lichtarz-drzewo światła', drugą - jako odwzorowanie rzeczywistego sprzętu. W pierwszej

Aszera Enzela ha-Lewiego, zm. 1890). Zob. też: Esther Vilenkin, Rebbetzin Chana and the Three Mitzvahs of Her Name, Chabad.org, https:/www.chabad.org/theJewishWoman/ article_cdo/aid/2917480/jewish/Rebbetzin-Chana-and-the-Three-Mitzvahs-of-Her-Name. htm [dostęp: 12 kwietnia 2021].

${ }^{25}$ Tarjag micwot..., micwat cedaka (micwa 479) i micwat tefila (micwa 433).

${ }^{26}$ Tłum. za: Jak modla się Żydzi. Antologia modlitw, oprac. Maciej Tomal, thum. Ewa Gordon i Maciej Tomal, Warszawa 2000, s. 99.

${ }^{27}$ Być może jednostkowy przypadek przyrównania kobiety do lichtarza, a w istocie do menory świątynnej - poprzez odniesienia do biblijnego opisu menory (Wj 25,31; 25,34 i in.), jest w epitafium Rozy córki Jaakowa, zwanej Złotą Różą, zmarłej w 1637 r. we Lwowie: „zostały złamane ramiona menory czystej, jej kielichy i ozdoby kwiatowe”. Odpis inskrypcji: Gawriel Suchestow, Macewet kodesz hu zichron cadikim, z. 2, Lemberg 1864, nlb.; fotografia i wolny przekład: Majer Bałaban, Żydzi lwowscy na przełomie XVI i XVII w., Lwów 1906, il. 50 oraz s. $41-42$.

${ }^{28}$ Symbolicznej interpretacji siedmioramiennej menory jako kobiety dokonała w XVI w. jedna z uczonych Żydówek, zob. Riwka bat Meir, Meneket Rywka, tłum. Estera Weres, [w:] Estera Weres, U źródet kobiecej literatury żydowskiej-Rebeka z Tykocina i jej „Meneket Rywka”, „Bibliotekarz Podlaski” 16 (2015), nr 1, s. 78 i n. 
konwencji elementy roślinne były mocno wyeksponowane, a nawet dominowały (il. 11, 20). Odczuwa się w takich realizacjach połączenie najwcześniejszego nagrobnego motywu - drzewa życia i związanych z nim obszernych treści - z mistycznym drzewem światła mającym swoje źródła w menorze świątynnej ${ }^{29}$. W drugiej konwencji przedstawiania odwzorowano mniej lub bardziej wiernie rzeczywiste sprzęty (il. 8, 26, 27, 30, 33). Nieraz tak wiernie, że możemy rozpoznać w nich popularne w wieku XVIII i XIX mosiężne wieloramienne świeczniki z heraldycznym orłem w zwieńczeniu trzonu ${ }^{30}$ czy pojedyncze lub wieloramienne srebrne lichtarze XIX- i XX-wieczne z seryjnej już produkcji platerów oferowanych przez takie firmy jak Norblin czy Fraget ${ }^{31}$. Spośród owych rzeczywistych przedstawień spotyka się też wieloramienne lichtarze wiszące (mogące służyć także na Chanukę).

Najwcześniejsze znane mi realizacje pochodzą z Kresów Wschodnich z Wiśniowca (Dwora córka Aharona Cwiego Hirsza Kahany, zm. 1775), Wyżnicy (Szejna córka Jehudy Lejba, zm. 1796 - il. 6), Satanowa (Batja córka Matitjahu, zm. 1799 - il. 7), a także z Południa - z Mikołowa (Sarel córka Awrahama, zm. 1796 - il. 5). Siedmioramienny lichtarz z Mikołowa nawiązuje swoją formą, tj. układem ramion, do menory świątynnej i jest bardziej znakiem niż ukazaniem sprzętu, co - przez prymitywizm wykonania - kojarzy się z przedstawieniami menory na obiektach sepulkralnych okresu starożytnego.

Pod koniec XVIII w. przedstawienia z lichtarzami wzbogacone zostają o motyw dłoni ukazanych w różnych gestach, przez co uzyskują swojego rodzaju narrację. Spotykamy rozwarte dłonie umieszczone ponad lichtarzem (wczesny przykład z Wyżnicy na steli Szejny córki Jehudy Lejba il. 6, zob. też il. 14, 29), a w późniejszych realizacjach nawet twarz zasłoniętą dłońmi (Chaja ..., zm. 1921, Śniatyń - il. 47; Fajga Rubinsztejn,

${ }^{29}$ Szerzej na ten temat zob. Goodenough, Jewish Symbols..., t. 4, rozdz. 4; Trzciński, Symbole i obrazy..., rozdz. V.A. Notabene - najwcześniejsze przedstawienie w takiej konwencji odnalazłem na nagrobku mężczyzny w Satanowie (Jicchak Ajzyk syn Cwiego, zm. 1791) - tu lichtarz siedmioramienny wyraźnie odnosi się do menory świątynnej.

${ }_{30}$ Por. Judaika $w$ zbiorach Muzeum Narodowego w Warszawie, oprac. Ewa Martyna, Warszawa 1993, nr kat. 118-120; Judaika w zbiorach Muzeum Narodowego w Krakowie. Rzemiosto artystyczne, druki i rękopisy, monety i medale, varia, oprac. Stanisława Odrzywolska, Monika Paś i in., Kraków 2018, nr kat. III/2-III/7.

${ }_{31}$ Zob. tamże, w katalogu warszawskim nr kat. 121, 123; w krakowskim nr kat. III/9III/12; a także oferty lichtarzy w katalogach wyrobów fabryk, np. Tow. Akc. Norblin, Br. Buch i T. Werner, Warszawa 1897; Fabryka wyrobów srebrnych i platerowanych Józef Fraget, Warszawa 1932. 
zm. 1937, Warszawa). Takie ujęcie odnosi się do zwyczaju zasłaniania dłońmi twarzy podczas błogosławieństwa świateł, by nie czerpać korzyści ze światła przed jego ukończeniem. Inna scena to zapalanie świateł szabatowych - ręka trzymająca zapaloną świecę przystawioną do świecy w lichtarzu (np. Lea Frajda córka Jaakowa, zm. 1895, Żelechów; Bejla Cipora córka Jaakowa, zm. 1900, Kazimierz Dolny - il. 32; Lea Tema córka Moszego Jechiela, zm. 1900, Kurów - il. 33).

Wyjątkową, rozbudowaną scenę widzimy na macewie z Horodyszczy (Sara Trajna córka Mordechaja, żona Noacha, zm. 1906 - il. 39). W izbie stoi stół, na nim lichtarz ze świecami, obok chała, przy stole fotel (domyślamy się, że przeznaczony dla pana domu będącego jeszcze na nabożeństwie szabatowym), obok stoi - pod postacią ptaka - pani domu i trzyma otwartą książkę, na której stronicach widnieje tekst: „Gdy otwiera usta, mówi mądrze, a język jej wypowiada dobre rady" (Prz 31,26). Fraza w epitafium: „Dusza jej powróciła na wysokości”, odnosi narrację do wymiaru wieczności. Analogiczną scenę, choć zredukowaną pod względem liczby motywów, spotykamy też w Radomsku (Chana córka Zeewa Wolfa, zm. 1862 - il. 21). Realistyczna i bogata w szczegóły scena rodzajowa znajduje się na macewie Idy Jochewed córki Moszego (zm. 1834, Brody). Ukazane jest wnętrze izby; przy podwieszonym do sufitu wieloramiennym lichtarzu typu „pająk” stoją domownicy pod postaciami ptaków - pani domu, zapewne podczas czynności zapalania świateł, a obok czworo dzieci. Można się domyślać, że czekają na pana domu, który zaraz powróci z szabatowego nabożeństwa.

Motyw szabatowego lichtarza odnajdujemy także na niektórych nagrobkach współczesnych wykonanych w formie tradycyjnej steli - tak jest np. w Łodzi (Stanisława Iza Ostojska-Nadel, zm. 2002 - il. 55; Judyta Abramson, zm. 2009).

\subsection{Dobroczynność}

W Misznie (Pirke awot 1,2) napisano: „Na trzech rzeczach opiera się świat: na Torze, na służbie <bożej> i na czynieniu miłosierdzia”. Czynienie miłosierdzia (gemilut chasadim) oraz cedaka (dosł. 'sprawiedliwość, w rozumieniu 'dobroczynność, a nawet 'jałmużna') wymienione są pośród głównych przykazań judaizmu z powołaniem się na zapis w Torze (Pwt 15,7-8) 32. Owo przykazanie obowiązuje wszystkich, z uwzględnieniem

32 W wymienionej edycji Tarjag micwot... jest micwat cedaka (micwa 479). 
indywidualnych możliwości, i wymieniane jest pośród pochwał w epitafiach co najmniej od XVI w. Odnoszące się do tej micwy motywy na nagrobkach widoczne są jednak dopiero od wieku XIX i występują znacznie częściej na macewach kobiet. Zapewne dlatego, że mężczyźni zajmowali się głównie pracą zarobkową i studiowaniem Tory, natomiast kobiety poświęcały więcej czasu na aktywność w bractwach pomocowych (przy czym należy zaznaczyć, że pochwała dotycząca studiowania Tory, mądrości, miała dla mężczyzny większą wartość od dobroczynności).

Najczęstszym motywem plastycznym ilustrującym dobroczynność jest puszka na datki. Bywa ona opatrzona napisem takim jak na rzeczywistych puszkach do cedaki: „Dar w skrytości dany uśmierza gniew” (Prz 21,14) ${ }^{33}$. Werset ten odnosi się do zwyczaju niejawnego wspomagania, by nie zawstydzać potrzebujących, a nawiązania do niego spotykamy w epitafiach. Nieco bardziej rozbudowane przedstawienia ukazują monety nad puszką lub dłoń wrzucającą monetę do puszki (il. 30, 32, 33, 53). Zmarła bywa też ukazywana pod postacią ptaka, który wrzuca do puszki monetę trzymaną w dziobie (il. 48). Wersje bez puszki reprezentują dwie otwarte dłonie naprzeciwko siebie - jedna trzymająca monetę, druga przyjmująca datek (il. 36) - co zapewne jest ilustracją frazy ze wspomnianego wersetu Tory: „otworzysz przed nim [ubogim] swoją rękę" (Pwt 15,8), oraz korespondującej z takimi obrazami parafrazy wersetu Prz 31,20, np.: „Swoją dłoń otwierała przed biedakiem, a swoje ręce wyciągała ku ubogiemu”. Oto kilka innych przykładów spośród licznych fraz tego rodzaju: „Biednych i ubogich karmiła swoim chlebem" (nawiązanie do Prz 22,9; Sara córka Szaula Dawida, zm. 1922, Szydłowiec), „W szabat i święto chały i chleb zapewniała biednym" (Ester córka Jicchaka Moszego, żona Eleazara Chajima, zm. 1931, Szydłowiec - tu z dodatkowym przedstawieniem kosza napełnionego chałami i chlebem - il. 53), czy ogólnie - „Czyniła sprawiedliwość i miłosierdzie".

Jedną z form dobroczynności, oprócz anonimowego wspierania biednych, jest także goszczenie potrzebujących, np. ubogich podróżnych, studentów jesziwy. W Misznie (Pirke awot 1,5) zawarte jest napomnienie: „Niech dom twój będzie otwarty na oścież i niech ubodzy będą twoimi domownikami”. Parafrazy tego zdania odnajdujemy w epitafiach pośród pochwał zmarłych. Od XIX w., ale bardzo rzadko, koresponduje z nim

33 Werset był na tyle rozpoznawalny, że zapisywano go niekiedy siglami: מביא, np. na XVI- i XVII-wiecznych oprawach skarbon w synagogach w Krakowie i Szydłowie, na nagrobku z 1897 r. w Suwałkach. 
ilustracja - wizerunek budynku, niekiedy dosłownie z otwartymi drzwiami. Takie przedstawienia znajdują się zarówno na nagrobkach mężczyzn, jak i kobiet, lecz z pewnym zróżnicowaniem. W Międzyrzecu Podlaskim na steli zamożnej Sary Riwki córki Dawida (zm. 1834) widnieje okazały budynek z napisem na elewacji: „Mądrość kobiet buduje” (Prz 14,1; cała fraza brzmi: „Mądrość kobiet buduje ich dom”), il. 12. W obszernym wierszowanym epitafium liczne pochwały korespondują z przedstawieniem owego domu:

mądra swoją dobroczynnością [...] Dom swój zbudowała w sprawiedliwości i rozdawała szczodrze ubogim ludu naszego. [...] Panny strapione gorzko zapłaczą: kto będzie podporą w nieszczęściu naszym? Załamują ramiona sieroty: gdzież szukać chleba i wody dla nas? Ach! Krzyczą wdowy, ach biada! Skąd przyjdzie pomoc dla nas? Bezsilna dusza biedaków: gdzie zdobędziemy buty i ubranie dla nas?

Podobny przykład odnajdujemy w Lesku na macewie Rachel córki Natana Cwiego (zm. 1930). Na pierwszym planie widnieje lichtarz, za nim okazały budynek opatrzony parafrazą wspomnianego napomnienia z Pirke awot: „Dom jej był otwarty na oścież” (il. 52). Tu również obszerne wierszowane epitafium zawiera pochwały zmarłej:

Wiele dzieł niech ją wysławia publicznie. Miłe jej uczynki miłosierne i prawe. Trudziła się i starała, by wesprzeć pokolenie prawych. Ochoczo karmiła głodnych. W szczodrobliwości serca pomagała każdemu proszącemu. Dom jej dla każdego pytającego był otwarty na oścież.

\subsection{Modlitwa}

Jak już wspomniano wyżej - pośród przykazań judaizmu wymieniona jest micwat tefila, będąca nakazem modlitwy ${ }^{34}$. Kobiety nie miały obowiązku odmawiania trzech modlitw dziennie ani uczestniczenia w nabożeństwach synagogalnych, czyniły to dobrowolnie. Według przepisów halachy, w tym zasady mechicy (rozdzielenia płci), kobiety modliły się w synagodze czy bet midraszu w osobnych pomieszczeniach - w babińcach (hebr. ezrat naszim, jid. wajber szul) pod przewodnictwem zogerki. Miały odrębne modlitewniki z odrębnymi modlitwami (tchines) zapisanymi nie w języku hebrajskim czy aramejskim, lecz w mame-loszn (na aszkenazyjskim obszarze

${ }^{34} \mathrm{~W}$ wymienionej edycji Tarjag micwot... jest to przykazanie 433 (opierające się na Pwt 10,20) z takim komentarzem: „Służenie Bogu (awoda) jest interpretowane przez rabinów jako tefila - modlitwa. W ciągu dnia odmawiane są trzy modlitwy: rano - szachrit, po południu - mincha, i wieczorem - maariw (arawit)". 
geokulturowym to język jidysz) ${ }^{35}$. Co więcej - początkowo drukowano je półkursywą, która z racji swojego głównego przeznaczenia zyskała miano wajber tajcz (kobiecy jidysz). Wydaje się oczywiste, że właśnie motyw modlitewnika stał się reprezentantem micwat tefila na macewach kobiet.

Motyw książki na nagrobkach na omawianym obszarze zauważalny jest od lat dwudziestych XIX w., najpierw na macewach mężczyzn, z czasem i kobiet ${ }^{36}$. W odróżnieniu od najbardziej typowych przedstawień dla mężczyzn - szereg książek lub szafka biblioteczna wypełniona książkami, na nagrobkach kobiet ukazywano jedną - co najwyżej dwie książki w układzie frontalnym - zamkniętą lub otwartą (il. 34, 41, 46). Alternatywnym motywem jest książka trzymana w dłoni (il. 50). Napisy, jakie umieszczano na książkach, pozwalają nam ułożyć inwentarz owego zbioru. Najczęściej jest to Korban mincha [Ofiara popołudniowa] lub Sidur Korban mincha [Porządek modlitw. Ofiara popołudniowa] (il. 34, 41) - tytuł najbardziej popularnego modlitewnika dla kobiet, drukowanego prawdopodobnie od schyłku XVI w. ${ }^{37} \mathrm{i}$ nadal wznawianego (co poświadczają strony internetowe dla religijnych kobiet), albo po prostu Sidur (il. 46). Inne tytuły to: Tchina [Prośba/błaganie/modlitwa] ${ }^{38}$ (il. 46), Cene u-rene [Idźcie i patrzcie] ${ }^{39}$, Nachalat cwi [Wspaniałe dziedzictwo] ${ }^{40}$ (il. 34). Ponadto Sidur tehilim [Porządek psalmów] lub Tehilim [Psalmy].

${ }^{35}$ Szerzej na ten temat zob. Andrzej Trzciński, Ezrat naszim/babiniec - jako przestrzeń rzeczywista, [w:] Nieme dusze? Kobiety w kulturze jidysz, red. Joanna Lisek, Wrocław 2010, s. 43-58; Lidia Jerkiewicz, Rola zogerek w tradycyjnej spoteczności żydowskiej. Rekonesans badawczy, [w:] tamże, s. 59-76; Joanna Lisek, Kol isze - glos kobiet w poezji jidysz (od XVI w. do 1939 r.), Sejny 2018, część I.

${ }^{36}$ Szerzej na ten temat zob. Andrzej Trzciński, Stowne i ikoniczne reprezentacje motywu księgi/ksiązki na nagrobkach żydowskich w Polsce, „Kwartalnik Historii Żydów” 275 (2020), nr 3, s. 509-550.

${ }^{37}$ Według Majera Bałabana: „w r. 1594 wydaje Avigdor Sofer modlitewnik dla kobiet znany pod tytułem Korban mincha (do dzisiaj używany)" - Majer Bałaban, Historia i literatura żydowska ze szczególnym uwzględnieniem historii Żydów w Polsce, t. 3: Od wygnania Żydów z Hiszpanii do rewolucji francuskiej (od Zygmunta Starego do trzeciego rozbioru Polski), Lwów 1925, s. 254.

${ }^{38}$ Tchines (1. poj. tchina) to modlitewne prośby, błagania o charakterze osobistym, odmawiane oprócz oficjalnych modlitw. Publikowano je w osobnych zbiorach, a autorkami niekiedy były kobiety.

${ }^{39}$ Parafraza Pięcioksięgu, w języku jidysz, przeznaczona dla kobiet, przypisywana Jakowowi ben Jicchakowi Aszkenazemu z Janowa, pierwsze wydanie prawdopodobnie w Lublinie w $1590 \mathrm{r}$.

${ }^{40}$ Być może chodzi o jidyszową adaptację fragmentów Sefer ha-zohar autorstwa Cwiego Hirsza ben Jerachmiela Chocza, opublikowaną po raz pierwszy we Frankfurcie nad Menem w $1711 \mathrm{r}$. 
Wspomniany już przykład z Horodyszczy (kobieta pod postacią ptaka czytająca 31. rozdział Księgi Przysłów), a także podobny z Warszawy (NN kobieta, lata dwudzieste-trzydzieste XIX w.), wreszcie liczne frazy z tejże Księgi (zwłaszcza 31,10-31 - będące pochwałą „niewiasty dzielnej”) świadczą o tym, że z tej partii Księgi Przysłów często czerpano w układaniu epitafiów kobiet. Jednak rzadko tekst koresponduje z obrazem - jako że samo ukazanie modlitewnika jest oczywiste. W jednym z przykładów typowemu przedstawieniu dłoni trzymającej książkę towarzyszy zdanie: „Odmawiała swoje modlitwy poranne i wieczorne" (Chana Hinda córka Szlomy, zm. 1927, Ostrowiec Świętokrzyski - il. 50).

Na koniec tego punktu spójrzmy na wybrane przykłady obszerniej ilustrujące wypełnianie przykazań: „Swoje ręce ku biedakowi wyciągała według potrzeby. Liczne obowiązujące przykazania Boga wypełniała. Zacnym sercem przykazań oddzielania ciasta, kąpieli rytualnej i zapalania świateł szabatowych przestrzegała. Prosto do domu modlitwy spieszyła” (Szejndel Rachma córka Szlomy Josefa, zm. 1891, Markuszów - il. 30); „Przestrzegała przykazania dobroczynności, wypełniając je z czystym sercem. Spieszyła do domu modlitwy, by modlić się gorliwie" (Sara córka Cwiego kohena, zm. 1892, Kazimierz Dolny); „Ręce swoje wyciągała ku biednym. Za sprawiedliwością i miłosierdziem podążała przez wszystkie dni swojego życia. Dom jej był otwarty na oścież” (wspomniana już Bejla Cipora córka Jaakowa, il. 32); „Przykazań oddzielania ciasta, kąpieli rytualnej i zapalania świateł szabatowych przestrzegała. Stosowała się do Tory i przykazań przez wszystkie dni swojego życia. W skrytości obdarowywała biednych" (Ester córka Jisraela, żona Altera Dawida kohena, zm. 1936, Kraśnik).

\section{Dom}

W epitafiach kobiet stosunkowo często obecne są treści dotyczące tradycyjnych powinności kobiety: prowadzenia domu, dbania o męża i domowników, wychowania dzieci - wyrażone bezpośrednio bądź pośrednio. Wymienione już micwot naszim (chala, nida, hadlakat nerot) też tego dotyczą, lecz nie pada w nich termin 'dom'. Pochwały kobiet w ich epitafiach - odnośnie do tematyki domu - zwykle zaczerpnięte są z Księgi Przysłów. Znajduja się pośród nich wersety ze słowem 'dom' (bajt): 14,1; 31,15; 31,21; 31,27; ale i takie, które dotyczą domu, choć słowo to nie pada: 31,13 i 19; 31,18. Kobietom poświęcony jest cały porządek Miszny - Naszim (Kobiety), 
lecz podmiotem tych misznajot są mężczyźni. Znamienne jest tam zdanie z traktatu Ketubot 5,5: „Oto są zajęcia, które żona wykonuje dla swego męża: miele [mąkę] i piecze [chleb], pierze, gotuje, karmi piersią niemowlę, ściele mężowi łóżko oraz przędzie wełnę" ${ }^{41}$. Dla swego męża, czyli dla domu, ponieważ - jak powiedział rabbi Jose: „Nigdy nie nazywałem mojej żony »moją żoną « [...] lecz »moim domem «" (TB, Szabat 118b). Taką rolę kobiety podtrzymywali w swoich pismach kolejni koryfeusze halachy - od Majmonidesa po współczesny nurt ortodoksyjny ${ }^{42}$.

Rola społeczna kobiet w świetle inskrypcji na ich nagrobkach jest taka jak w czasach biblijnych i talmudycznych, a ich powinności wymieniane są jako pochwały. Oto kilka przykładów: „wyciągała po kądziel swoje ręce, wrzeciono trzymały jej dłonie" (Prz 31,19; Ester córka Moszego, zm. 1570, Lublin); ,wstawała wcześnie, gdy była jeszcze noc, i dawała pożywienie swym domownikom i porcję swej służącej" (Prz 31,15; NN kobieta, zm. 1651, Lublin); „w mądrości zbudowała swój dom” (por. Prz 9,1 i 14,1; Rejna córka Szimszona, żona Saadji, zm. 1808, Lublin); „Nie gaśnie jej lampa" (por. Prz 31,1843; Szprinca córka Szlomy, żona Daniela ha-kohena Arczykowskiego, zm. 1858, Warszawa); „Czuwała nad biegiem spraw swojego domu przez wszystkie swoje dni” (por. Prz 31,27; Cirel córka Jehoszuy, zm. 1909, Jaworzno); „Pracowała dzień i noc, by wspomóc swego męża w <studiowaniu > Tory" (Riwka Szejndel córka Zimela, zm. 1919, Sławków); „Mąż jej całymi dniami zajmował się Torą i służbą <bożą>, a ona sama dostarczała chleb i dawała pożywienie dla swojego domu" (por. Prz 31,15; Chaja Perel córka Jisraela Moszego, zm. 1935, Lubartów).

W jednym z epitafiów (NN kobieta, zm. 1910, Zaklików) natrafiamy na wyizolowany epitet wyrażony aramejskimi słowami saweta be-wejta (dosłownie: 'starsza kobieta w domu'). Wyrażenie to pochodzi z dysput mędrców Talmudu (TB, Arachin 19a), którzy reinterpretując werset Kpł 27,7, skonstatowali, że w domu starszy mężczyzna jest tylko ciężarem, a starsza kobieta jest skarbem ze względu na pomoc w różnych pracach.

${ }^{41}$ Cyt. za: Miszna Naszim (Kobiety), wstęp, thum. i oprac. Roman Marcinkowski, Warszawa-Bellerive-sur-Allier 2016.

${ }^{42}$ Menachem Elon, [hasło] Woman: The Judicial Perspective: Women and the Israeli Courts, [w:] Encyclopaedia Judaica. Second Edition, red. Fred Skolnik, Michael Berenbaum, Detroit 2007, t. 21, s. 197.

${ }^{43}$ Cały werset brzmi: „Wyczuwa pożytek ze swojej pracy, jej lampa także w nocy nie gaśnie". Na marginesie warto zauważyć, że jego trawestacji użyto jako peryfrazy śmierci: „Wszak zgasła w nocy jej lampa” (Ita córka Jissachara Bera, zm. 1785, Szczebrzeszyn). 
Następnie Raszi ujął to tak: „starsza kobieta w domu jest skarbem w domu i dobrym znakiem dla domu"44.

Do ukazania obrazu domu na macewach zainspirowały pomysłodawców i twórców przedstawień zapewne treści przede wszystkim z Księgi Przysłów. Przedstawienia takie zauważalne są od lat dwudziestych wieku XIX, w okresie eksplozji nowych motywów. Występują w dwu wersjach: jako wnętrze izby mieszkalnej albo konwencjonalny obraz budynku. Obydwa warianty stosowano na macewach i mężczyzn, i kobiet. Tu zwrócimy uwagę na specyficzne konteksty dotyczące kobiet.

Wnętrze izby widzimy w przedstawieniach ukazujacych początek szabatu - przygotowanie wieczerzy i zapalanie świateł. Obrazy te maja wspólny przekaz z przywołanymi już wcześniej przykładami dotyczącymi micwy hadlakat nerot (il. 21, 39).

Widok budynku jako domu mieszkalnego występuje częściej, lecz na przypadki, w których tekst koresponduje z obrazem, natrafiamy rzadko. Front budynku opatrzonego cytatem z Księgi Przysłów 14,1 („Mądrość kobiet buduje ich dom"45) znajduje się na wspomnianym już nagrobku z Międzyrzeca Podlaskiego (Sara Riwka córka Dawida, il. 12), z dopełnieniem w epitafium: „dom swój zbudowała w sprawiedliwości”. Ten sam cytat odnajdujemy na elewacji budynku wyobrażonego na steli w Szydłowcu, obok którego umieszczony jest duży ptak siedzący na drzewie, poniżej na ziemi dwa małe ptaki (NN kobieta, lata dwudzieste-trzydzieste XX w.) ${ }^{46}$. Te przykłady pozwalają na analogiczne odczytanie podobnych przedstawień, które nie są opatrzone wskazówkami tekstowymi. Na cmentarzu żydowskim w Warszawie znamienna jest znaczna liczba nagrobków kobiet z lat dwudziestych-sześćdziesiątych XIX w. z konwencjonalnym motywem domu mieszkalnego (il. 18). Budynkowi towarzyszą tam inne motywy - lichtarz (w tym ze złamanymi świecami), drzewo (także złamane), ptaki, macewa. Niekiedy dom ma otwarte drzwi i okna, co może być nawiązaniem do

${ }^{44}$ Szlomo ben Jicchak zwany Raszi, komentarz do Kpł 27:7.

${ }^{45}$ Fraza ta, jak również Prz 9,1 oraz ich różne parafrazy zauważalne są w epitafiach kobiet co najmniej od XVI w., np.: „,w swojej mądrości zbudowała swój dom, wyciosała sobie kolumn siedem” (Nechla ..., zm. 1585, Kraków); „Jej roztropność i mądrość zbudowała sobie dom i wyciosała sobie kolumn siedem" (Riwka córka Majzla, żona Szmelkego, zm. 1614, Przemyśl). Interpretacji pojęć ‘mądrość' i ‘dom’ z wersetów Prz 9,1 i 14,1 dokonała z pozycji kobiety w XVI w. Riwka bat Meir, Meneket Rywka..., s. 75 i n.

${ }^{46}$ Znane mi jest tylko przedstawienie - zdjęte z kamienia metodą litograficzną, zob. Exhibition of Tombstones of the Jewish Cemetery in Szydlowiec (Poland). Graphic prints by Jacek Antoni Zielinski and Lucyna Krakowska, Museum of Ethnography and Folklore, December 1963 - February 1964, Tel Aviv 1963, kat. 38. 
ludowych zabiegów magicznych dokonywanych po śmierci domownika ${ }^{47}$. Owe wątki wanitatywne stanowią równoległą warstwę przekazu.

Należy tu wspomnieć jeszcze o innym temacie przedstawień, wspólnym dla mężczyzn i kobiet, choć z wyraźną przewagą ilościową na macewach kobiet, ukazującym owce wychodzące ze stajni i zmierzające ku studni. Temat ten zapewne miał swój początek w Warszawie w latach dwudziestych XIX w. i rozprzestrzenił się na inne tereny, funkcjonując aż do lat trzydziestych XX w. Główną jego treścią jest ukazanie osieroconych dzieci - liczba owiec zwykle odpowiada liczbie dzieci. Budynek w większości przykładów nie przypomina stajni, lecz murowany dom (niekiedy dwukondygnacyjny) z oknami, poddaszem, dachem krytym dachówką. I tak jak owce umownie reprezentują ludzi, tak budynek przedstawia dom mieszkalny (il. 31).

Wątek dotyczący troski o byt dzieci, ich wychowania i religijnego kształcenia zauważalny jest w epitafiach dopiero od XIX w. Mimo że w epitafiach mężczyzn nierzadko pośród pochwał odnajdujemy frazy o prowadzeniu czy wychowywaniu synów/dzieci według Tory, na nagrobkach kobiet wyrażane to bywa z większą dozą prywatności i czułości. Oto kilka przykładów: „,[Dzieci] na jej kolanach uczyły się Tory [...] i stosowały do jej napomknień” (Serka córka Jicchaka, zm. 1829, Lublin); „Swoje dzieci prowadziła ścieżką uczciwości, wychowała je ku Torze i wszelkim właściwym przymiotom” (Bejla Gitel córka Szimona, zm. 1908, Jaworzno); „Miłosierdziem i koroną łaskawości była dla swych dzieci [...] zawsze było jej wolą, by uczyć dzieci Tory” (Nechama córka Jisraela, zm. ok. 1916, Sandomierz); „Ku Torze i przykazaniom wychowała swoje potomstwo, zawsze uczyła swoje dzieci moralności" (Blima Erlich, zm. 1936, Sławków). Oprócz wymienionych wcześniej przykładów prac domowych spotykamy też bardziej dosłowne opisy: „Starała się w pocie czoła, by wykarmić swoje dzieci” (Mela ..., żona Icyka, zm. 1866, Inowrocław); „Wielce troszczyła się przez dni swojego życia, by wykarmić siebie i swoje dzieci" (Fajga córka Jicchaka ha-Lewiego, zm. 1919, Sławków).

Wszelkie powyższe wątki obrazowano na nagrobkach kobiet za pomocą motywu ptaka w różnych konfiguracjach, na ile jest to możliwe przy tak ograniczonych środkach wyrazu. Oprócz prostych, hieratycznych układów (il. $7,14,22,23,34,51)$ są sceny z pewną dozą narracji: matka-ptak

${ }^{47}$ Olga Goldberg-Mulkiewicz, Obrzędy żałobne i pogrzebowe Żydów polskich, „Polska Sztuka Ludowa” 40 (1986), nr 1-2, s. 104; Krajewska, Symbolika płaskorzeźb..., s. 56. Otwarte drzwi wiążą się też ze wspomnianym w punkcie 2.2 napomnieniem z Miszny (Pirke awot 1,5), lecz przedstawienia ilustrujące dosłownie tę sentencję nie są specyficzne dla nagrobków kobiet. 
karmiący małe ze swej piersi, tulący młode pod skrzydłami, karmiący pisklęta w gnieździe (il. 27, 54).

\section{Motywy związane ze śmiercią}

Różne odniesienia słowne dotyczące śmierci odnajdujemy już na najstarszych zachowanych nagrobkach na omawianym obszarze, tj. na XIIIi XIV-wiecznych stelach ze Śląska, pochodzących jeszcze z czasów piastowskich i nawiązujących do wcześniejszych z obszaru Europy. W epitafiach charakterystyczne jest unikanie słów 'umrzeć' i 'śmierć' (met, mawet), a zastępowanie ich omownymi substytutami ${ }^{48}$. Do początku XIX w. próżno szukać w sferze ikonicznej jakichkolwiek elementów formalnych, które kierowałyby lub choćby sugerowały przekaz ku znaczeniom przemijania i śmierci, natomiast od tego czasu jest ich wiele. Realizowane były w dwu nurtach. Pierwszy z nich to modyfikacja tradycyjnych motywów występujących już na nagrobkach (ale nie tylko) i poddawanie ich prostym zabiegom formalnym - jak np. złamanie, ścięcie, odwrócenie lub komponowanie scen ilustracyjno-narracyjnych - w celu wyrażenia uczuć żałoby, żalu, rozpaczy, opuszczenia po śmierci bliskich. Drugi nurt, bardziej radykalny, to przejmowanie obcych motywów oraz form nagrobków z otoczenia chrześcijańskiego, niosących treści wanitatywne. Takie rozszerzenie zasobu przedstawień wiąże się z wpływami prądów emancypacyjnych i oświecenia żydowskiego (haskala) oraz asymilacją do kultury otoczenia w wieku XIX. Wątki wanitatywne na nagrobkach żydowskich omówiono w osobnym opracowaniu $^{49}$, tu zwrócimy uwagę tylko na przedstawienia na macewach kobiet i tylko z nurtu pierwszego, w tym drugim nurcie bowiem dla naszim nie odnotowuje się specyficznych form ${ }^{50}$.

48 Takich określeń odnalazłem ponad siedemdziesiąt, przeważnie czasownikowych zob. Andrzej Trzciński, „Zaszło jego stońce w potudnie”. Stowne i ikoniczne obrazowanie śmierci na nagrobkach żydowskich $w$ Polsce $w$ XIII-XX wieku, „Kwartalnik Historii Kultury Materialnej” 66 (2018), nr 4, s. 415 i n.

49 Tamże.

${ }^{50}$ Ograniczę się tu do ich wymienienia. Są to następujące motywy: gaszone pochodnie, znicz, złamana kolumna, ruiny budowli, urna okryta całunem, trumna na katafalku, nagrobek lub widok cmentarza, klepsydra, uroboros, motyl, mak, płaczące postacie ludzi lub aniołów. 


\subsection{Jej świeca zgasła}

W XIX w. lichtarz ze świecami był już powszechnym motywem na nagrobkach kobiet. Obrazowanie śmierci realizowano poprzez prosty, formalny zabieg - ukazanie złamanej świecy. Najwcześniejsze takie przedstawienie znane mi jest z Warszawy (Ester córka Awigdora, zm. 1807 - il. 8; zob. też il. 20, 27, 30, 35, 36). Ów motyw może być wzmocniony umieszczoną przy nim frazą lamentacyjną: „Dlatego płaczę” (Lm 1,16; NN kobieta, zm. ok. 1830, Warszawa). Niekiedy lichtarz ze złamaną świecą jest składnikiem sceny narracyjnej. Taki przykład spotykamy w Radomsku (Chana córka Zeewa Wolfa - il. 21) - obok lichtarza widnieje stół, na nim dwie chały, powyżej, w zwieńczeniu steli, przycupnięty ptak - to zmarła Chana patrzy już z nieba na przerwany szabat. Fraza w epitafium: „odeszła w święty szabat" - dopełnia odczytania sceny.

Jednym z omownych określeń zgonu jest 'zgaszenie' (hebr. kawa 'zgasnąć'), a jego odpowiednikiem ikonicznym - zgaszona świeca. W schematycznych przedstawieniach nie jest to dostatecznie jasne, lecz niekiedy ujawnia to napis umieszczony między świecami: „Zgasła jej świeca” (np. Rachel córka Jehoszuy Szragi, zm. 1864, Lwów - il. 22). W Warszawie na nagrobkach kobiet zmarłych przed szabatem powtarza się następujące przedstawienie: cztery pojedyncze lichtarze ze świecami, dwie skrajne świece zapalane są od świec trzymanych w dłoniach, na dwu środkowych osiadł szponami duży ptak (Rachel Lea córka Jisraela, zm. 1836). Rabin Arthur Levy tak interpretuje tę scenę: „Pobożne ręce zajęte są zapalaniem świec szabatowych, lecz już opuszcza się śmierć (pod postacią ptaka) i gasi światło. Te kobiety umarły w wigilię szabatu" ${ }^{51}$. Nieco inne rozwiązanie takiego konceptu odnajdujemy na licznych nagrobkach z drugiej połowy XIX w., gdzie widnieje złamana świeca, której płomień dodatkowo gasi dziobem mały ptak $^{52}$ (np. Rachel córka Awrahama, zm. 1867, Radomsko; Lea córka Hilela, Kazimierz Dolny - il. 26).

\subsection{Opuszczenie/osierocenie}

Figura ptaka, jak już można było zauważyć wyżej, służy do przekazu różnych treści. Najczęściej jednak reprezentuje osobę zmarłą i jej rodzinę. Odlatujący ptak to kolejna metafora obrazowa i słowna zastosowana w celu uniknięcia bezpośredniości w wyrażaniu śmierci. Oto dwa przykłady: Ze

${ }^{51}$ Levy, Jüdische Grabmalkunst..., s. 61-62 oraz il. 57.

52 Rozmiary ptaków nierzadko rządzą się prawami kompozycji całego przedstawienia. 
złamanego drzewa odlatuje ptak; w epitafium koresponduje z obrazem tekst: „Złamane zostało drzewo życia i odleciała od nas Cipora w wiośnie jej dni. Dziewczynka Fajgel [...] w piętnastym roku jej życia" (Cipora Fajgel Rozensztejn, zm. 1914, Prużana - il. 43). Na innym nagrobku przedstawieniu ptaka w locie towarzyszy umieszczony obok napis: „Ach! Odleciała jak gołąb sprzed moich oczu” (Zlata Juta córka Szlomy Arjego Krancberga, zm. 1921, Otwock). Takich przedstawień jest niemało, jednak niewiele z komentarzem słownym i wówczas musimy te niedopowiedziane odczytywać przez analogie do objaśnionych. Wyjątkowo rzadko i późno na nagrobkach pojawia się martwy ptak - ukazywany z reguły poprzez zabiegi formalne obrazu. Na tradycyjnej steli Bejli Mirel Szefner (zm. po 1900, Łódź; il. 35) uczynione jest to metaforycznie - ponad złamanym drzewem i lichtarzem ze złamaną świecą widzimy ptaka w locie, który jest odwrócony głową do dołu ${ }^{53}$. W Warszawie - na stelach znacznie odbiegających od tradycyjnych - niemal pełnoplastycznie przedstawiono śpiącego lub martwego ptaka, podobnego do pawia, z bezwładnie opuszczoną głową na długiej szyi (Stefanja z Oppenhajmów Leonowa Behack, zm. 1914 - il. 44; Sara Dwora córka Chajima Rotenberga, żona Jicchaka Meira Blama, zm. 1926). Nietradycyjny nagrobek Gustawy Ałapinowej (zm. 1912, Warszawa; il. 42) to pełnoplastyczna rzeźba przedstawiająca siedzącego na skale dużego ptaka pochylającego się nad małym, leżącym, martwym.

Częste są sceny ukazujące w różnych konfiguracjach ptaka dużego, a obok małe, niekiedy siedzące w gnieździe, niekiedy tulone pod skrzydłami. Liczba małych ptaków wskazuje zwykle liczbę osieroconych dzieci, niekiedy takich „ptaszków” bywa nawet osiem. Jeśli obrazom towarzyszą niekonwencjonalne partie lamentacyjne, poznajemy szczegóły, np.: „Dniem i nocą z oczu naszych płyną łzy na wspomnienie śmierci naszej drogiej matki" (Lea Minsze córka Awrahama Jicchaka, żona Mordechaja Ajzykowskiego, zm. 1901, Horodyszcze - duży ptak siedzący na złamanym drzewie, obok dwa małe); „Łzy płyną z oka nieustannie. Trzy sieroty pozostały bez opieki” (Edel córka Chajima, zm. 1911, Horodyszcze trzy ptaszki przy złamanym drzewie); „Niewiasta uboga w lata, poszła do swojego świata zbyt wcześnie i nie zdołała wychować dzieci za życia” (Bejla Obcas córka Zusmana, zm. 1937, Szydłowiec - duży ptak siedzący na złamanym drzewie, obok w koszyku-gnieździe dwa ptaszki; il. 54). Nierzadko

${ }^{53}$ Zabieg 'odwrócenia/przewrócenia' realizowano też z motywem korony, z cytatem „Spadła korona z naszej głowy” (Lm 5,16) lub jego parafrazami, identycznie jak na nagrobkach mężczyzn. 
przedstawiano same sieroty, np. pięć małych ptaków w zwieńczeniu steli i korespondujący z nimi fragment inskrypcji: „pozostawiła pięcioro małych sierot" (Ester Rozenfeld, zm. 1907, Kraków - il. 40), czy siedem ptaszków siedzących na złamanym drzewie, z podobnym odniesieniem w inskrypcji (Ester córka Gedalji, zm. 1909, Brześć Litewski).

W wyjątkowych przypadkach narracja łącząca obraz i tekst jest bardzo intensywna. Na macewie w Prużanie ukazano dwa ptaki - dużego (stojącego na pniu złamanego drzewa) i pod nim małego, obok których znajduje się nadłamane drzewo z sześcioma owocami na gałęziach i siódmym spadającym z drzewa. W epitafium czytamy: „Zległa do porodu i urodziła, chłopca dała nam [...] Gałąź wraz z owocem została odcięta. Narzekajcie i biadajcie nad obojgiem pochowanych. [...] Frajda córka Moszego Cwiego i chłopczyk" (zm. 1905); il. 38. Tak poprzez figury ptaków i drzew opowiedziano o tym, że matka i jej siódme dziecko zmarli podczas porodu.

W XIX w. - analogicznie do stadka ptaków - popularne były także sceny rodzajowe ukazujące trzódkę owiec wychodzących ze stajni do wodopoju przy studni lub stojących przy złamanym drzewie - jako dzieci opuszczone, osierocone po śmierci rodzica ${ }^{54}$. Tu również liczba owiec odpowiada zwykle liczbie osieroconych dzieci. Niekiedy w epitafium zawarte jest dopowiedzenie słowne, np.: „opłakują ją trzy sieroty” (Chana Mirjam Bursztynski, zm. 1905, Łódź; il. 37, zob. też il. 31).

\section{Związek z personaliami}

Charakter niektórych imion kobiecych, takich jak bardzo popularne hebrajskie Cipora i jego jidyszowy odpowiednik Fajga (oznaczające 'ptak'; zdrobniale Fajgla, Fajglecha) czy równie popularne jidyszowe Bluma (kwiat), Rojza/Roza (róża), pozwalał na gry obrazowo-słowne na nagrobkach kobiet o takich imionach ${ }^{55}$.

Najwięcej tropów odnaleźć można w związku z motywem ptaka ${ }^{56}$. Wczesne przykłady - pojedynczy ptak z rozwiniętymi skrzydłami (odlatująca dusza?) - zachowały się w Lublinie na bloku horyzontalnym nagrobka

${ }^{54}$ Ten temat występuje też na nagrobkach mężczyzn, jednak rzadko.

55 Tego rodzaju koincydencje pojawiają się jednocześnie na nagrobkach mężczyzn w związku z takimi motywami, jak: lew (przy imionach Arje Lejb, Jehuda), jeleń (Cwi Hirsz, Naftali), niedźwiedź (Dow Ber), rzadziej - wilk (Zeew Wolf), gołąb (Jona), ryba (Fiszel), wół (przy przydomku Szor).

${ }_{56}$ Wczesne, jednostkowe przykłady spoza omawianego obszaru zachowały się w Wormacji z XIV w.: ptak obok lilii na macewach młodzieńców i panien, np. Mina córka Jicchaka, 
Fajgli córki Jehoszuy Heszela, żony Naftalego Hirsza, zm. 1691 (il. 3) oraz na steli Fajgli córki Michela, zm. 1778. W późniejszym okresie takich zbieżności jest wiele w rozmaitych konfiguracjach przedstawień. Przywołam tu jeden z przykładów o wymowie eschatologicznej. Na ściętym pniu siedzi ptak trzymający w dziobie kosz wypełniony owocami. To symboliczne wyobrażenie Fajgi córki Aharona Jeszaji Elijahu (zm. 1845, Warszawa), a zarazem jej duszy, która niesie kosz wypełniony owocami dobrych uczynków zmarłej (il. 16). Nieodparcie nasuwa się tu nierzadko przywoływana w epitafiach (choć nie w tym) fraza o dobrych uczynkach, które poprzedzają duszę w drodze do nieba i są jej protektorami. Podobnie jest z imieniem Tojbe (jid. 'gołębica') - np. wizerunek pojedynczego gołębia na steli Sary Tojbl Anisfeld córki Szmuela Cwiego Hirsza (zm. 1871, Kraków). Analogiczne zbieżności dotyczą imienia Bluma (kwiat) - jeden z wczesnych przykładów to dwa okazałe kwiaty pośród innych motywów na macewie Blumy córki Cwiego (zm. 1743, Lublin) $)^{57}$.

Kwiat róży bywa ukazywany na nagrobkach kobiet o takim imieniu, np.: Roza córka Szlomy Zalmana (zm. 1826, Lublin) - dwie główki rozwiniętych kwiatów i owoc (il. 9); Rachel Róża z Eisenmanów Szajder (zm. 1882, Warszawa) - bukiet róż w wazonie; Róża z Kaminerów Adolfowa Finkelhaus (zm. 1926, Warszawa) - wieniec z kwiatów róży (il. 49). Wykorzystywano także znaczenie nazwiska, tak np. w Słonimie - w przyczółku steli umieszczono przedstawienie kwiatu róży ze złamaną łodygą, a w epitafium czytamy: „Jej kwiat umarł. Do kwiatu róży podobna [...] Uboga w lata, jej dni zostały ucięte. Ach! Nie rozwiną się z nich plony" (Lea Rozenblum, zm. 1889 - il. 28).

W Radomsku na steli Rachel Malki córki Josefa (zm. 1873) widnieje kuriozalne połączenie wizerunku owcy (hebr. rachel - 'owca') z lichtarzem - zwierzę zamiast szyi i głowy ma tulejkę lichtarza, w niej złamaną świecę (il. 24).

zm. 1319; Jehuda syn Moszego ha-Lewiego, zm. 1324. Zob. Brocke, The Lilies..., s. 7 i n., oraz dokumentacja w bazie Epidat, http://www.steinheim-institut.de/cgi-bin/epidat.

${ }^{57}$ Spoza omawianego obszaru najwcześniejszy ze znanych i precedensowy przykład takiej zbieżności to pięciopłatkowy kwiat flankowany gałązkami na macewie Blumy córki Jaakowa, zm. 1365, Spira - zob. Epidat, http://www.steinheim-institut.de/cgi-bin/ epidat?id=spy-17\&lang=de. Główki kwiatowe cztero-, sześcio- $\mathrm{i}$ ośmiopłatkowe występują w czasie XIII-XV w. na macewach mężczyzn i kobiet w Wormacji, jednak bez związku $\mathrm{z}$ imionami. 
Na cmentarzu w Warszawie odnajdujemy kilka przedstawień z odniesieniami do biblijnych imienniczek zmarłych kobiet ${ }^{58}$. Oto na nagrobku Riwki córki Simchy (zm. 1835) ukazana jest scena rodzajowa: na pierwszym planie ręka trzymająca dzban nad studnią, w tle - drzewa, trzy wielbłądy i namiot (il. 13). To odniesienie do biblijnej sceny spotkania wysłannika Abrahama z Rebeką przy studni (Rdz 24,10-22). Na steli Mirjam córki Jehudy Lejba (zm. 1839) widnieje grupa instrumentów muzycznych, w tym dwa bębenki i instrumenty dęte (il. 15). Ponad tą płaskorzeźbą jest napis: „I odeszła Mirjam w czasie swojej starości. I wzięła w swoje ręce dobro”. Całość nawiązuje do sceny biblijnej, w której prorokini Mirjam wraz z innymi kobietami śpiewa i tańczy, przygrywając sobie na bębenkach (Wj 15,20). W oryginalnym tekście czytamy: „I wzięła Mirjam w swoją rękę bębenek"; na marginesie wypada wspomnieć, że redaktor inskrypcji zastosował tu grę słowna - hebrajskie tof (bębenek lub tamburyn) zamienił na tow (dobro). Podobnie na dolnej części steli Mirjam Ester córki Szmuela Majzelsa, żony Meira Tenenbauma (zm. 1854) ukazano grupę instrumentów muzycznych - na pierwszym planie wyeksponowany bęben, w tle instrumenty dęte ${ }^{59}$. Natomiast w przyczółku tej steli widnieje pejzaż sygnalizowany pagórkami i dwoma drzewami (żywym i uschniętym), a głównym motywem są tryskające obficie ze skały strumienie wody (il. 19). Obraz jest podpisany: Beer szel Mirjam [Studnia/źródło Mirjam]. Inspiracją tego przedstawienia jest legenda oparta na ustępie biblijnym (Lb 20,1-13), mająca swoje początki w Talmudzie, a następnie liczne wersje w literaturze późniejszej ${ }^{60}$. Z kolei na macewie Sary córki Cwiego

${ }^{58}$ Tego rodzaju obrazowanie - aluzyjne, rozbudowane sceny biblijne, przy tym z ukazaniem postaci ludzkich i ich twarzy - stosowano już od schyłku XVII w. na cmentarzu sefardyjskim w Ouderkerk pod Amsterdamem, np.: Rebeka przy studni (Rdz 24,10-22; Ribca molher de Semuel Levy Ximenes, zm. 1694), spotkanie Racheli z Jakubem (Rdz 29,9-12; Rachel hija de Yeuda Vega, zm. 1695), Anna i kapłan Heli w Świątyni (1Sm 1,9-18; Hana mulher de Yeuda Vega, zm. 1701), Mojżesz z tablicami przymierza oraz triumf Mordechaja jadacego na koniu (Wj 19 i 20; Est 8,8-11; Mosseh de Mord. Senior, zm. 1730). Zob. Louis Alvares Vega, Het Beth Haim van Ouderkerk: Beelden van een Portugees-Joodse begraafplaats, Assen 1979, s. 40, 41, 54.

${ }^{59} \mathrm{~W}$ tekście biblijnym wymieniony jest tylko bębenek, natomiast w legendach także flety - zob. Louis Ginzberg, The Legends of the Jews, t. 3: Bible Times and Characters from the Exodus to the Death of Moses, Philadelphia 1909: The Song at the Sea, https://www.sacredtexts.com/jud/loj/loj303.htm.

${ }^{60}$ Źródłem legendy są zapewne ustępy w: TB, Szabat 35a; Taanit 9a; następnie m.in. Midrasz Tanchuma, Chukat 20; Raszi, komentarz do Lb, 20:10:2; Mosze ben Nachman zwany Ramban, komentarz do Lb, 20:8:2. Syntetyczne omówienia zob. Alan Unterman, Encyklopedia tradycji i legend żydowskich, tłum. Olga Zienkiewicz, Warszawa 1994, s. 306-307; Rafał Żebrowski, [hasło] Źródło (studnia) Miriam, [w:] Polski stownik judaistyczny. Dzieje, 
Jaakowa (zm. ok. 1850) ukazano mały budynek z otwartym otworem wejściowym, obok nadłamane drzewo. Na budynku widnieje napis: „Gdzie jest Sara? W tym oto namiocie" (il. 17). Są to wyrwane z kontekstu frazy ze sceny nawiedzenia Abrahama i Sary przez trzech wysłanników Boga ( Rdz 18,9). Jednocześnie zastosowano tu koncept, w którym hebrajski wyraz ohel (namiot) odnosi się do wspomnianego w tekście biblijnym namiotu mieszkalnego z czasów nomadycznych, jak i do specyficznej formy nagrobka - małego budynku wzniesionego nad grobem.

\section{Podsumowanie}

Do pierwszej ćwierci XVIII w. nie istniały jakiekolwiek motywy ikoniczne różnicujące nagrobki kobiet i mężczyzn (oprócz męskich potomków kapłanów i lewitów). Początkowe próby zróżnicowania polegały na wykorzystaniu niektórych motywów powszechnych, takich jak ptak czy korona, i zestawianiu ich z treściami dotyczącymi kobiet. W czwartej ćwierci XVIII w. wprowadzony został na nagrobki kobiet motyw lichtarza, który szybko rozpowszechnił się i stał się elementem identyfikacyjnym.

Na nagrobkach kobiet znacznie częściej występowały wątki związane z dobroczynnością, mimo że ta micwa obowiązywała wszystkich. Można $\mathrm{z}$ tego wnioskować, że kobiety w większym stopniu udzielały się w bractwach pomocowych typu gemilut chasadim, choć należy pamiętać, iż dla mężczyzn pochwała dobroczynności nie była priorytetowa.

Treści w epitafiach kobiet - także te korespondujące $\mathrm{z}$ motywami plastycznymi - przedstawiane jako pochwały lub opis zalet, dotyczą przede wszystkim tradycyjnych kobiecych powinności wobec domu, męża i dzieci. Ich źródła tkwią w tekstach biblijnych i literaturze rabinicznej. Cytaty i ich parafrazy w znacznej mierze pochodzą z Księgi Przysłów - z partii o „dzielnej kobiecie” (Prz 31,10-31).

Na nagrobkach kobiet dużo częściej występują treści obrazowe i słowne dotyczące uczuć: troski i miłości macierzyńskiej, żalu po śmierci bliskich, opuszczenia, osierocenia.

Jakich treści nie ma na nagrobkach kobiet w odróżnieniu od nagrobków mężczyzn? Nie ma atrybutów i odniesień do studiowania Tory i uczoności,

kultura, religia, ludzie, red. Zofia Borzymińska, Rafał Żebrowski, Warszawa 2003, t. 2, s. 847. Przykłady legend: Ginzberg, The Legends...: Miriam's Well, https://www.sacred-texts.com/ jud/loj/loj303.htm; Micha Josef Bin Gorion, Żydowskie legendy biblijne, tłum. Robert Stiller, Gdynia 1996, cz. 2, s. 84-85: Źródto Mirjam. 
do aktywności w sferze publicznej - do profesji, zarówno religijnych (u mężczyzn np. sofer, mohel, rofe, chazan), jak i później świeckich (np. pisarz, malarz, działacz polityczny), co oczywiście wynika z pozycji i roli kobiety w społeczności patriarchalnej, a co badacze nazywają podwójną marginalizacją lub podwójnym wykluczeniem ${ }^{61}$. Informacje takie pojawiają się dopiero w okresie międzywojennym na nagrobkach kobiet $\mathrm{z}$ rodzin zasymilowanych do kultury otoczenia, o czym świadczą też nietradycyjne formy nagrobków i inskrypcje w językach nieżydowskich ${ }^{62}$.

${ }^{61}$ Przegląd problematyki i literatury z opcji her-story zob. Aleksandra Oniszczuk, $\dot{Z} y$ dówki w polskiej historii, [w:] Materiały z konferencji „Polsko-żydowskie dziedzictwo Rzeczypospolitej. Wyzwania pamięci i edukacji”, Muzeum Historii Żydów Polskich POLIN, 14-16 listopada 2019, https://polin.pl/system/files/attachments/Aleksandra\%20Oniszczuk\%20-\%20 $\%$ C5\%BByd\% C3\%B3wki\%20w\%20polskiej\%20historii\%20-\%20podsumowanie $\% 20$ wyk\%C5\%82adu.pdf [dostęp: 12 kwietnia 2021].

${ }^{62}$ Oto kilka przykładów z cmentarza żydowskiego w Warszawie: „lekarz dentysta” (Berta Stillman, zm. 1935), „Dr Med.” (Stanisława Talerman, zm. 1937), „pielęgniarka” (Edzia Blumencwajg, zm. 1935), „założycielka i przełożona gimnazjum, kierowniczka szkoły powszechnej” (Cecylja Goldman-Landauowa, zm. 1935), „nauczycielka publ. szkoły powsz.” (Zofja z Orensteinów Rozenowa, zm. 1935), „dziennikarka, członek rzeczywisty Syndykatu Dziennikarzy Warszawskich” (Sewa Fiszmanówna, zm. 1936), „magister filologii klas.” (Cecylja Graff ur. Halber, zm. 1935). 


\section{Ilustracje}

Wszystkie ilustracje (ułożone i ponumerowane chronologicznie) są własnością autora.

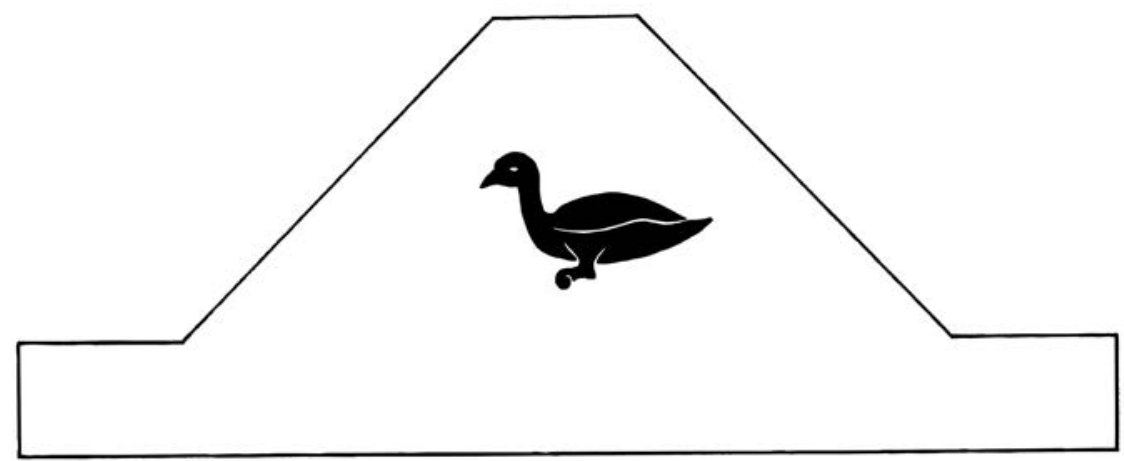

Il. 1. Rachel(?) córka Judy, żona Natana, zm. 1580 lub 1597, Kraków

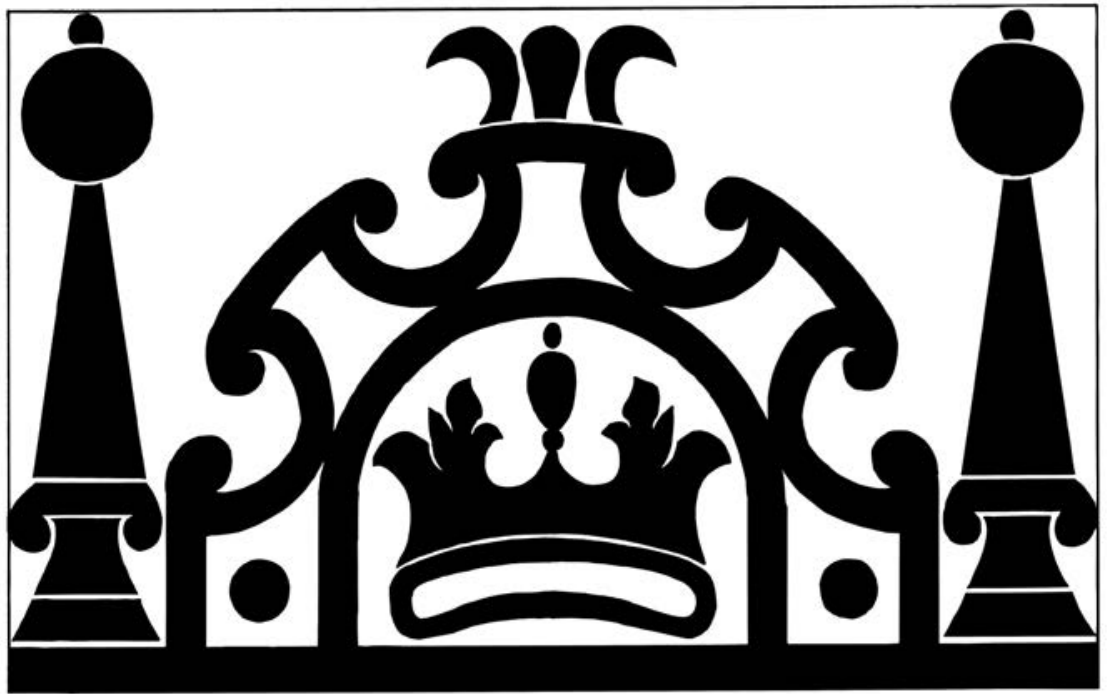

Il. 2. NN kobieta, pierwsza połowa XVII w., Kraków 


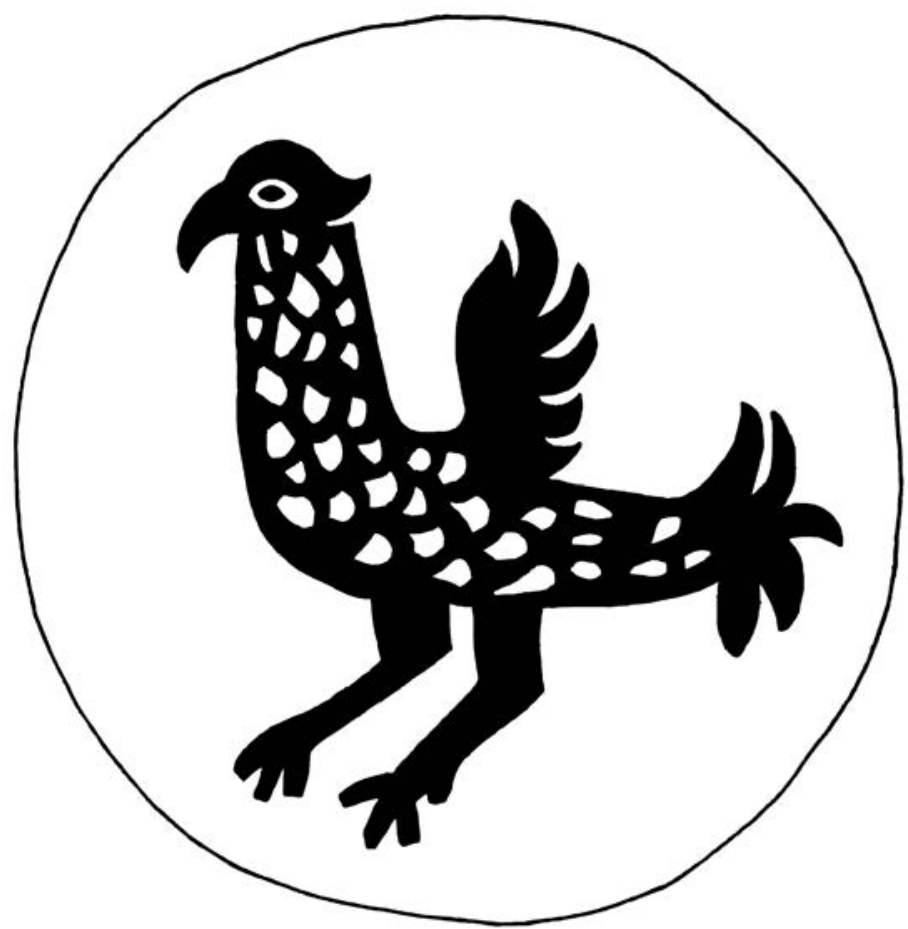

Il. 3. Fajgla córka Jehoszuy Heszela, żona Naftalego Hirsza, zm. 1691, Lublin

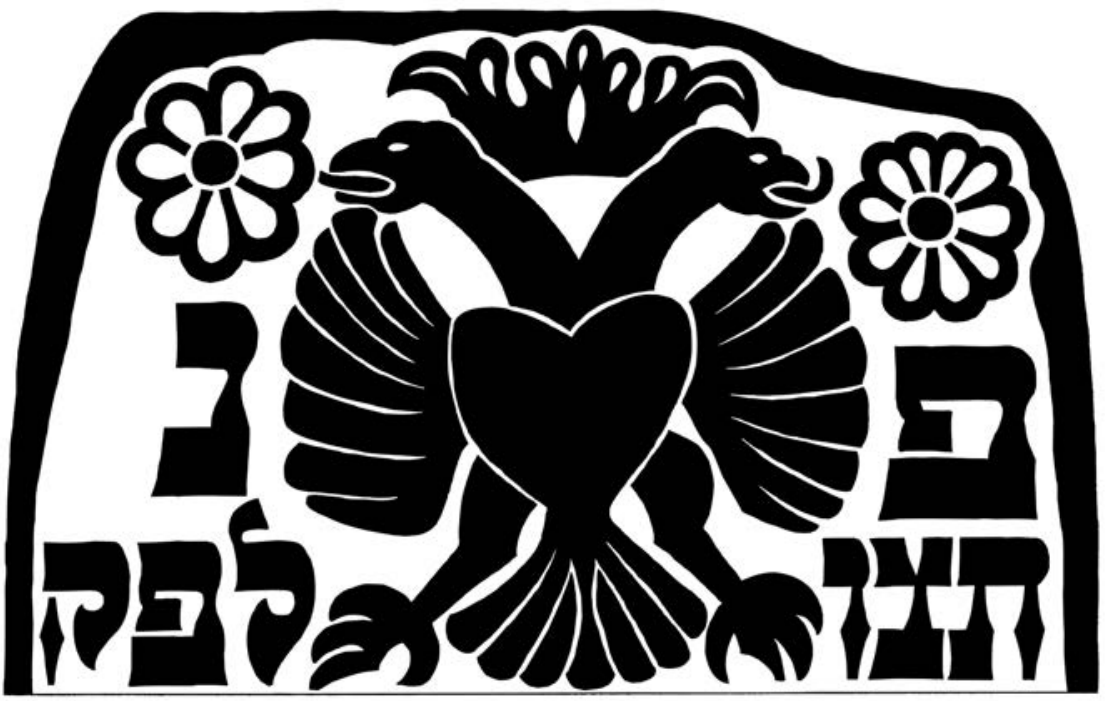

Il. 4. Bejla córka Jaakowa Jisraela, zm. 1736, Krzeszów 


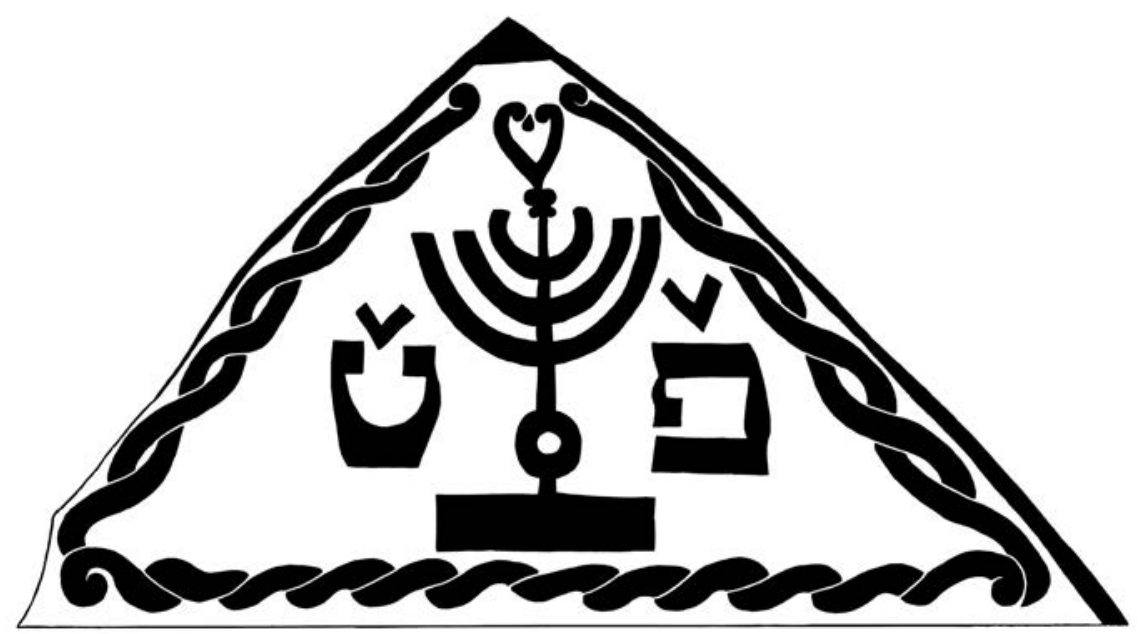

Il. 5. Sarel córka Awrahama, zm. 1796, Mikołów

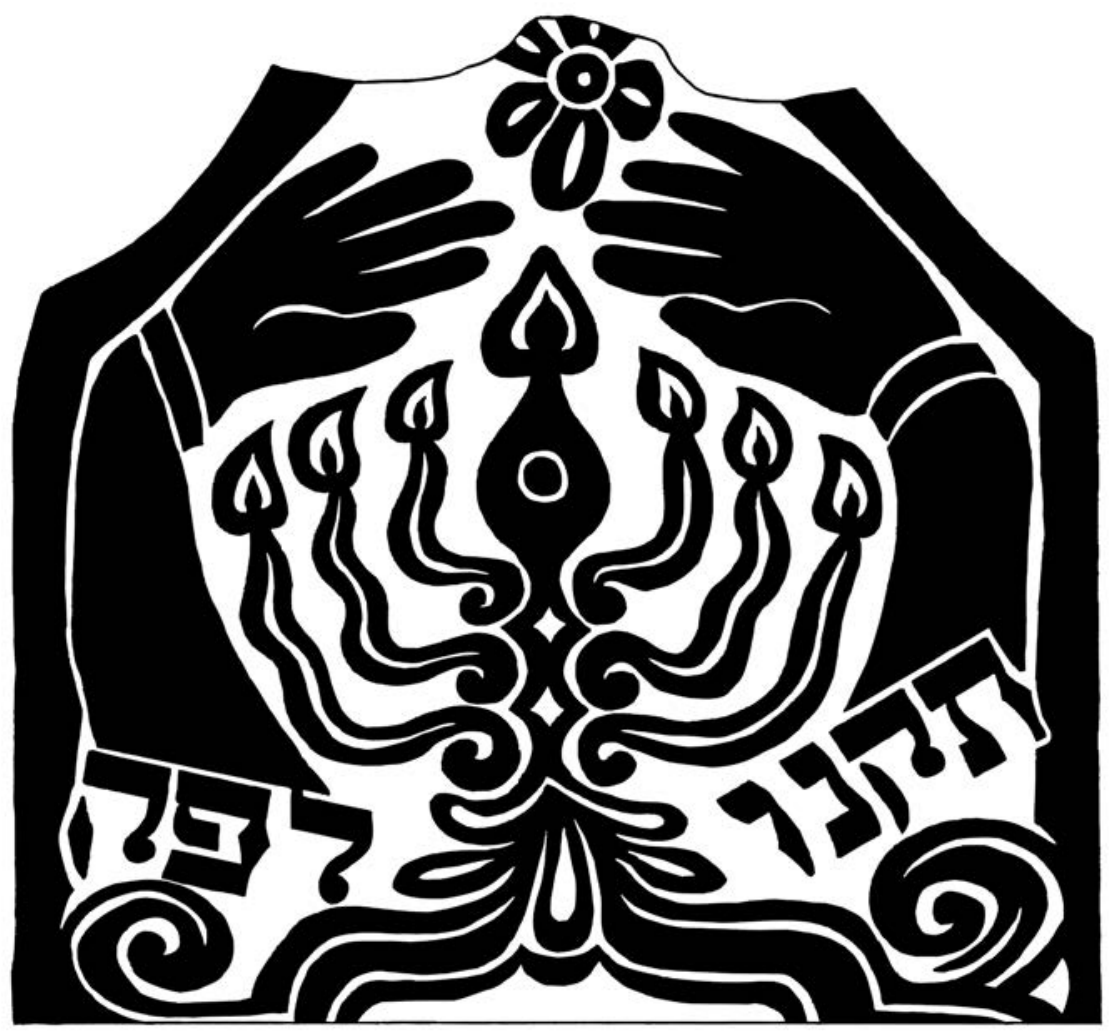

Il. 6. Szejna córka Jehudy Lejba, zm. 1796, Wyżnica 


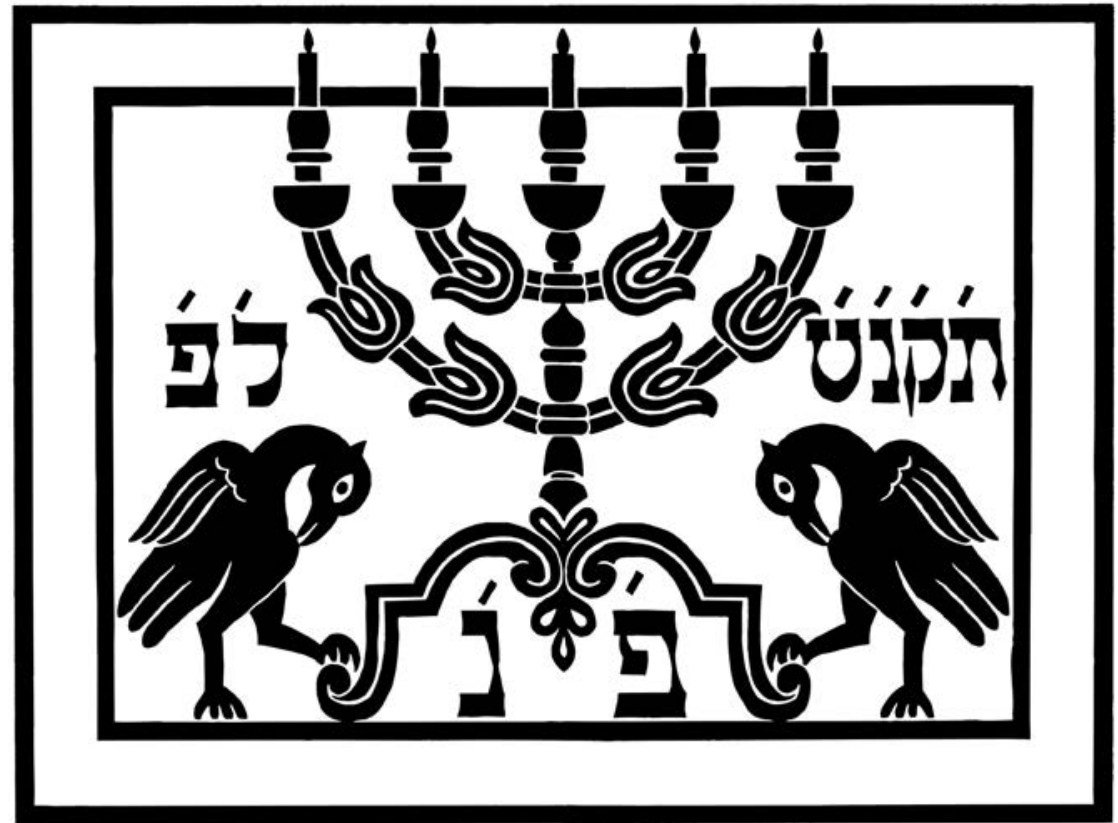

Il. 7. Batja córka Matitjahu, zm. 1799, Satanów

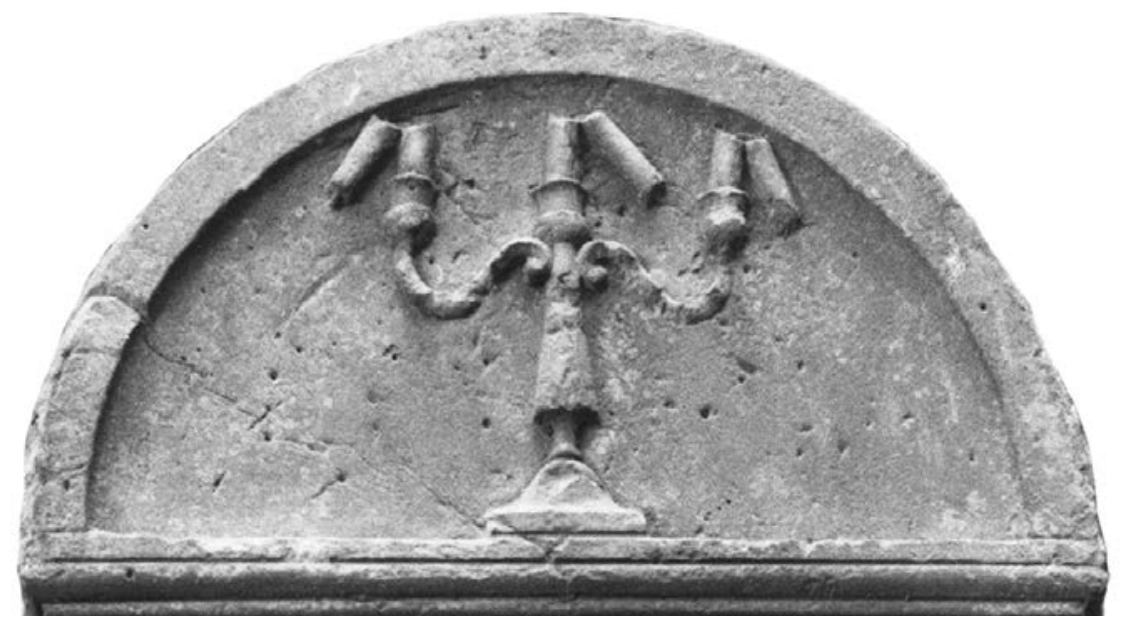

Il. 8. Ester córka Awigdora, zm. 1807, Warszawa 


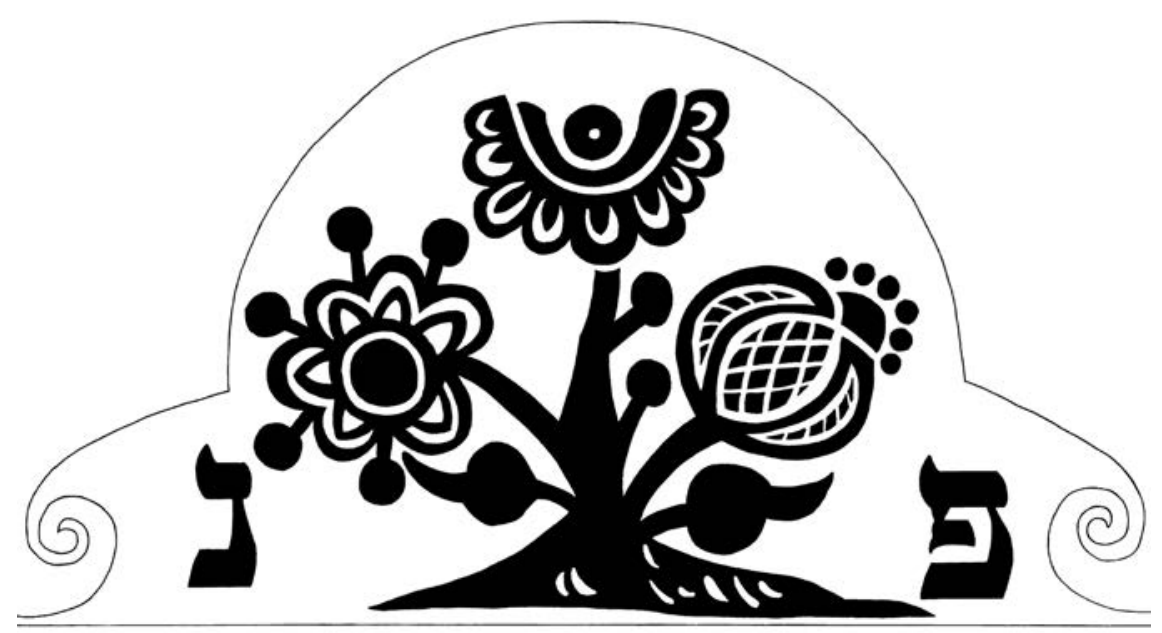

Il. 9. Roza córka Szlomy Zalmana, zm. 1826, Lublin

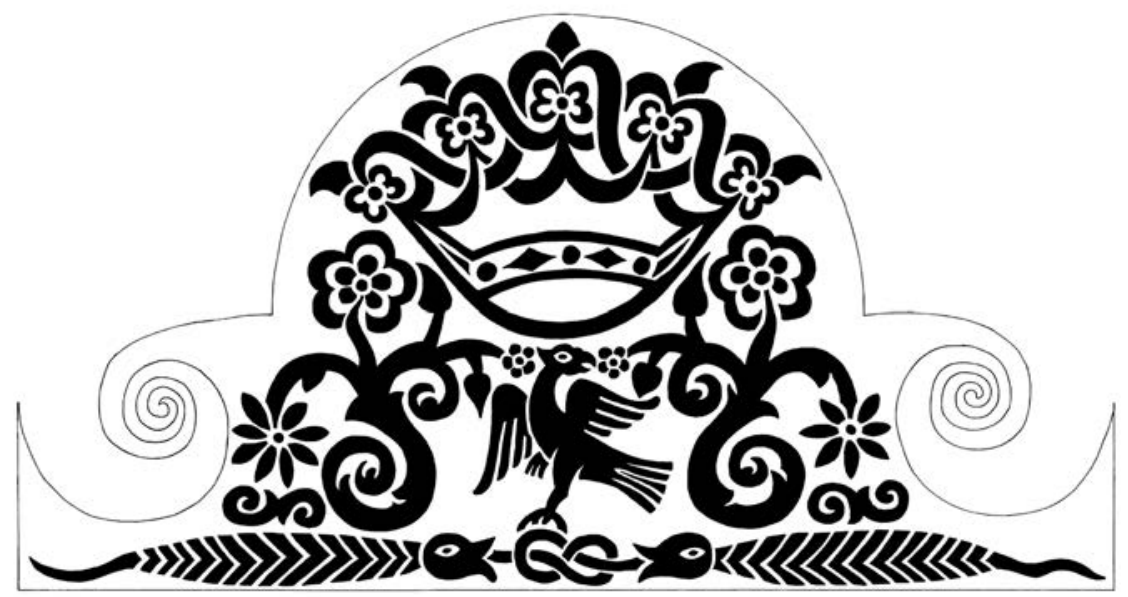

Il. 10. Jenta Pesa córka Meira, zm. 1830, Lublin 


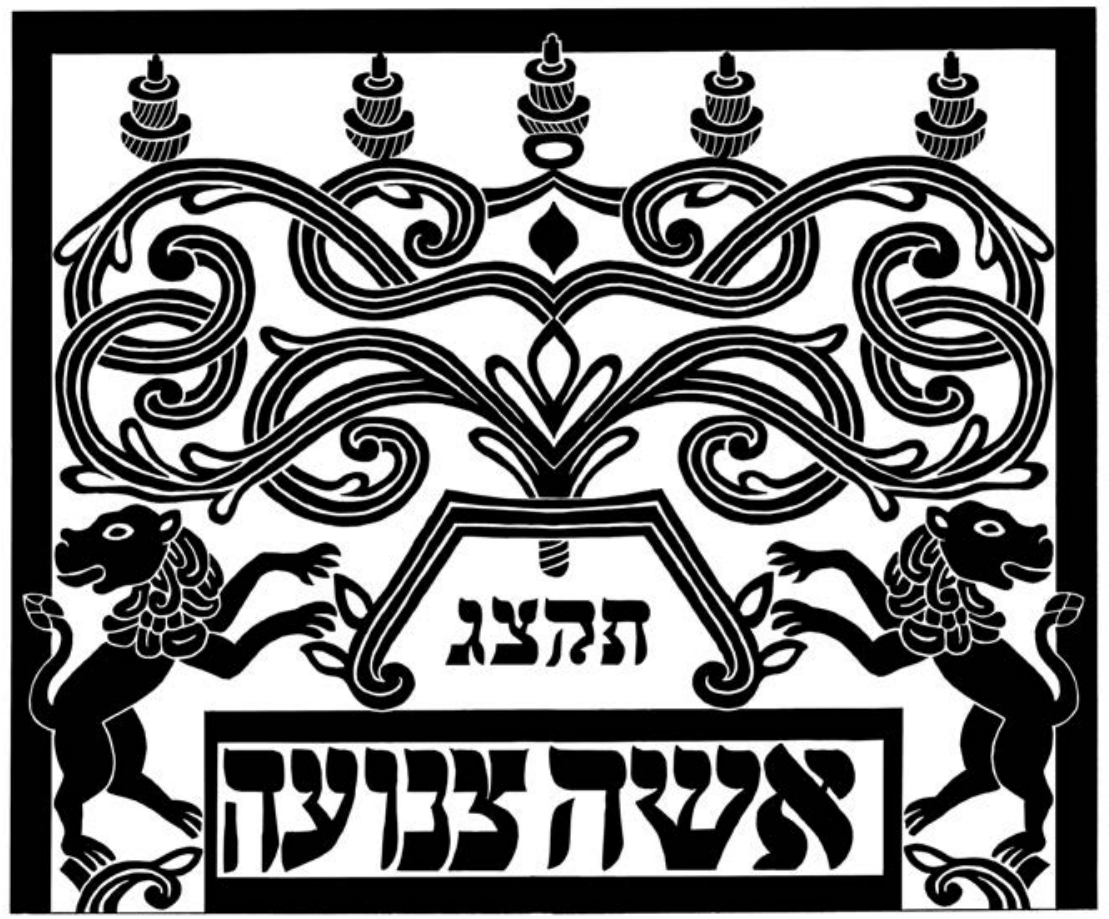

Il. 11. Zisel córka Szmuela, zm. 1833, Peczeniżyn

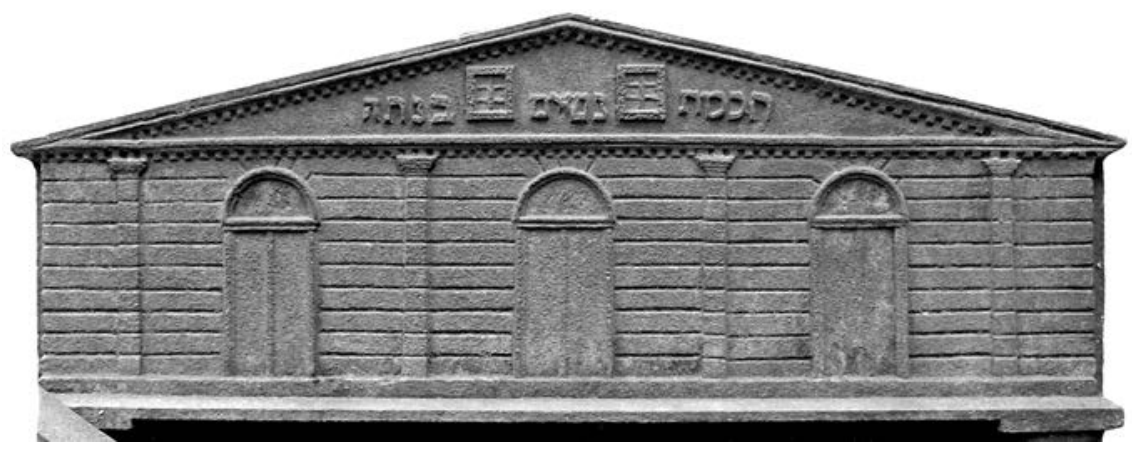

Il. 12. Sara Riwka córka Dawida, zm. 1834, Międzyrzec Podlaski 


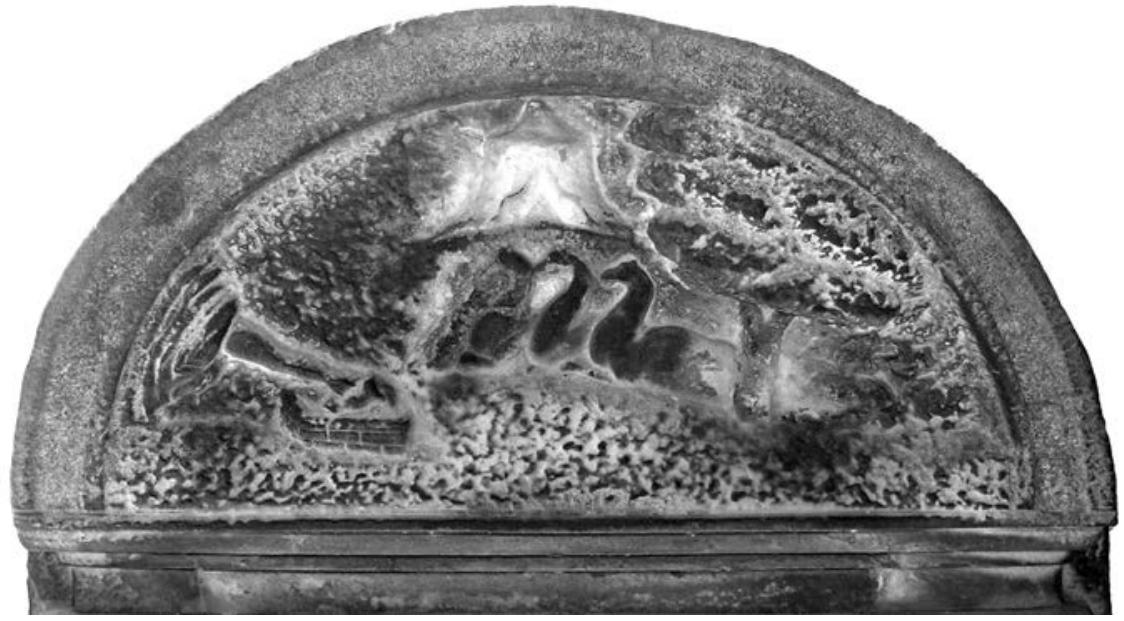

Il. 13. Riwka córka Simchy, zm. 1835, Warszawa

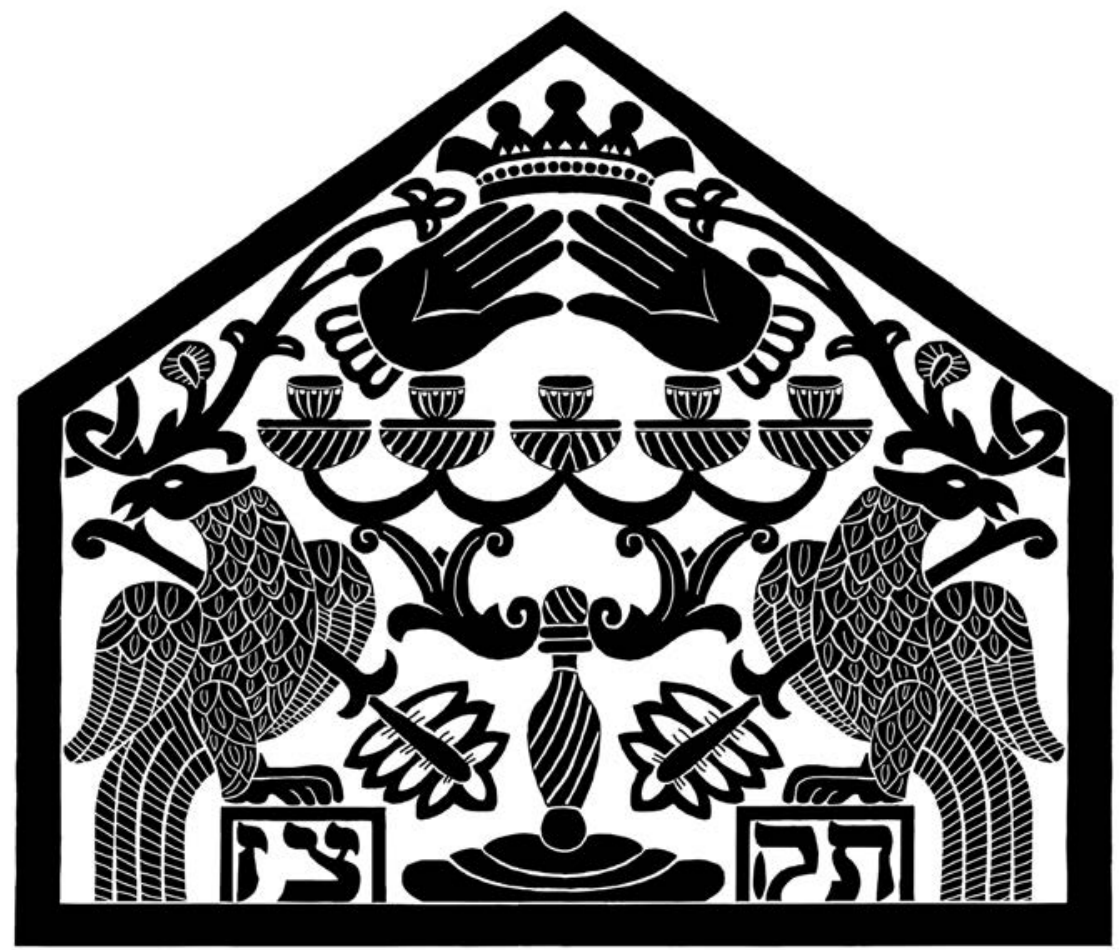

Il. 14. Malka córka Aszera Anczela, zm. 1837, Peczeniżyn 


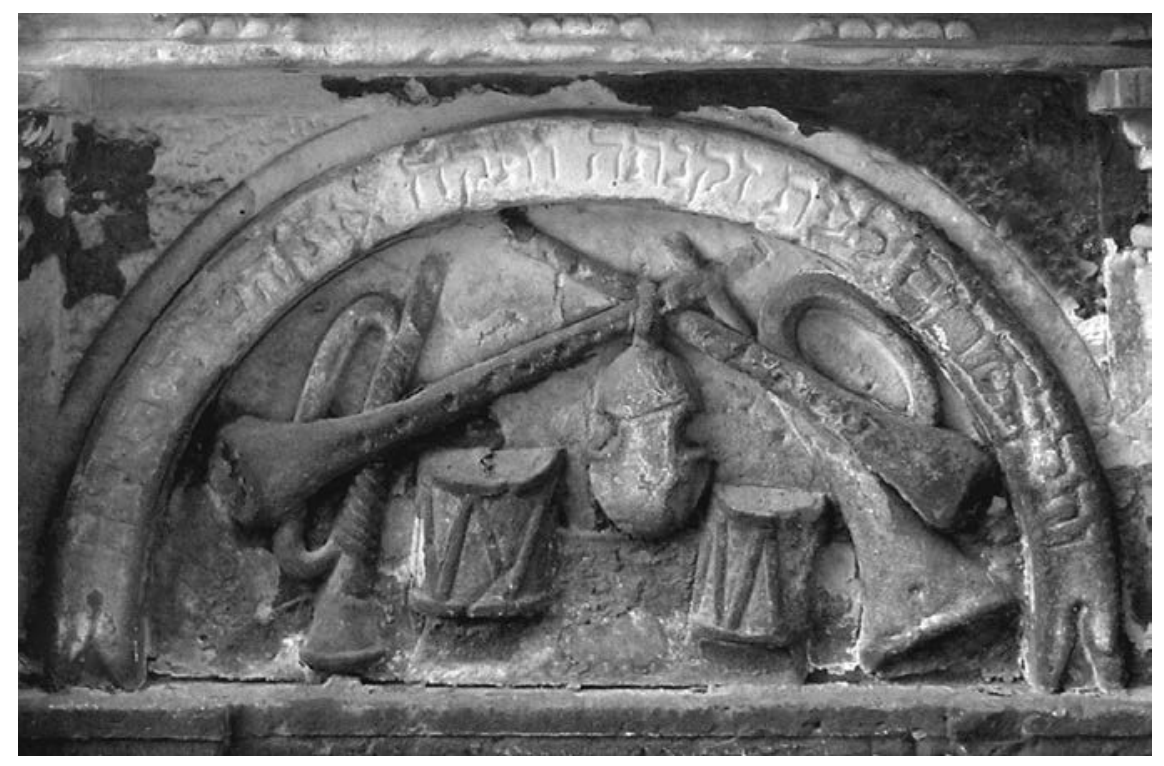

Il. 15. Mirjam córka Jehudy Lejba, zm. 1839, Warszawa

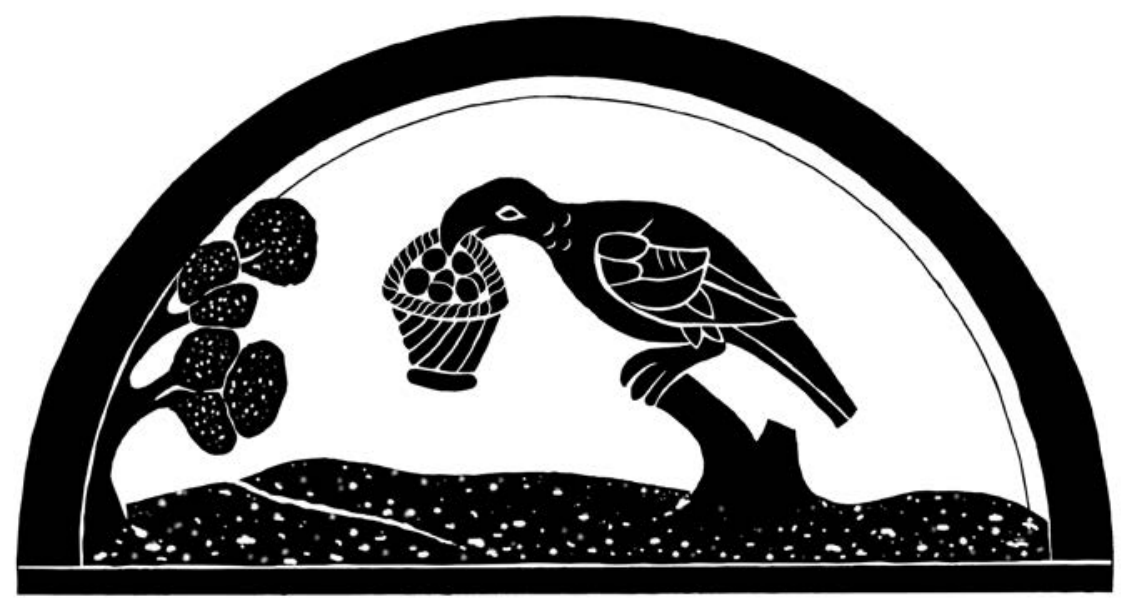

Il. 16. Fajga córka Aharona Jeszaji Elijahu, zm. 1845, Warszawa 


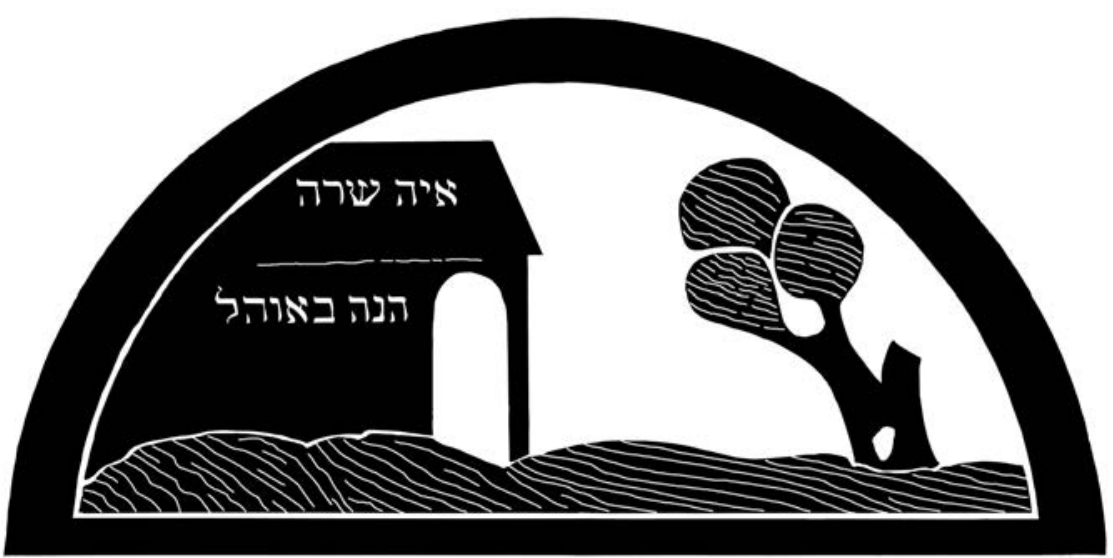

Il. 17. Sara córka Cwiego Jaakowa, zm. ok. 1850, Warszawa

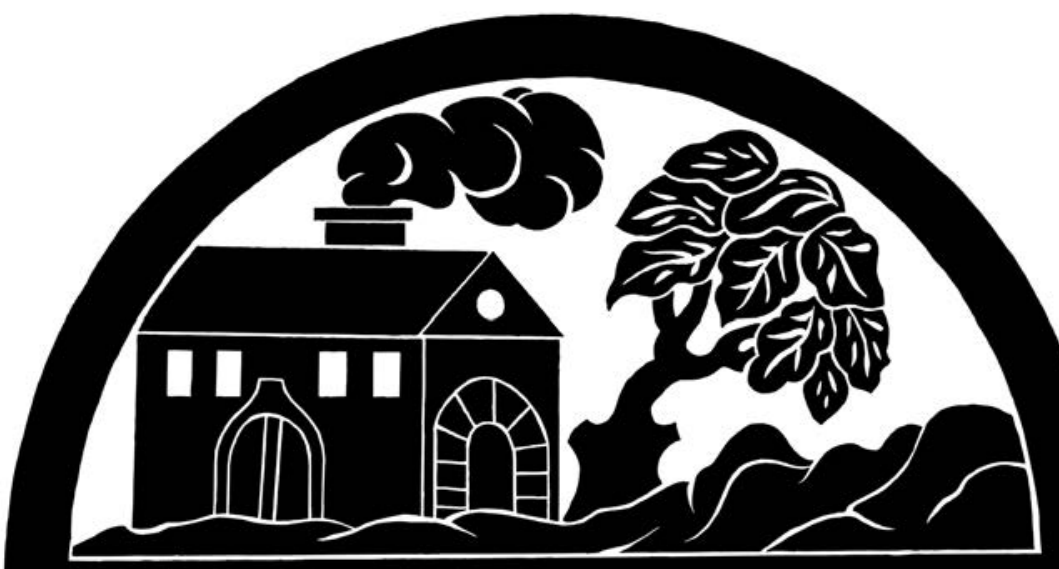

Il. 18. Bluma córka Moszego segala Glikmana, zm. 1854, Warszawa 


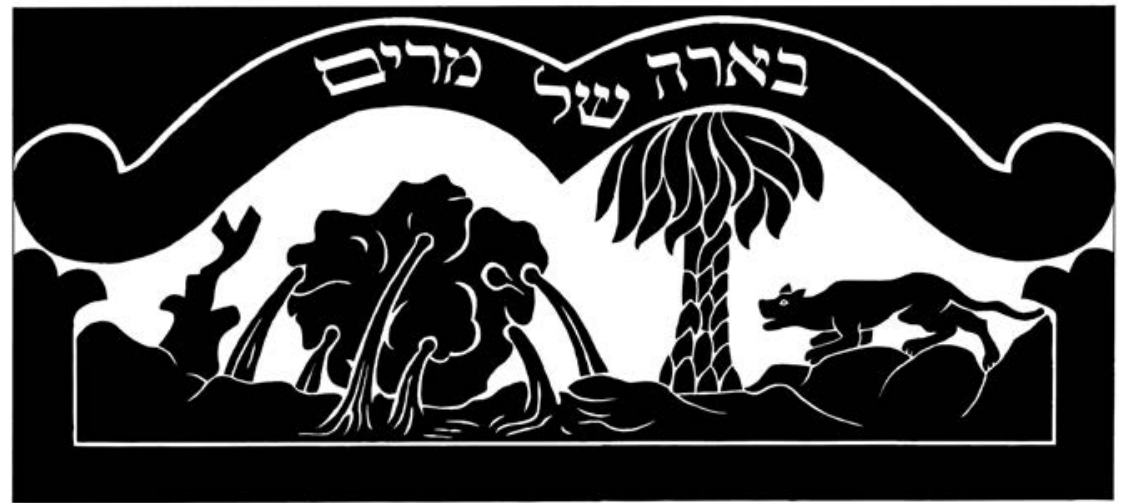

Il. 19. Mirjam Ester córka Szmuela Majzelsa, żona Meira Tenenbauma, zm. 1854, Warszawa

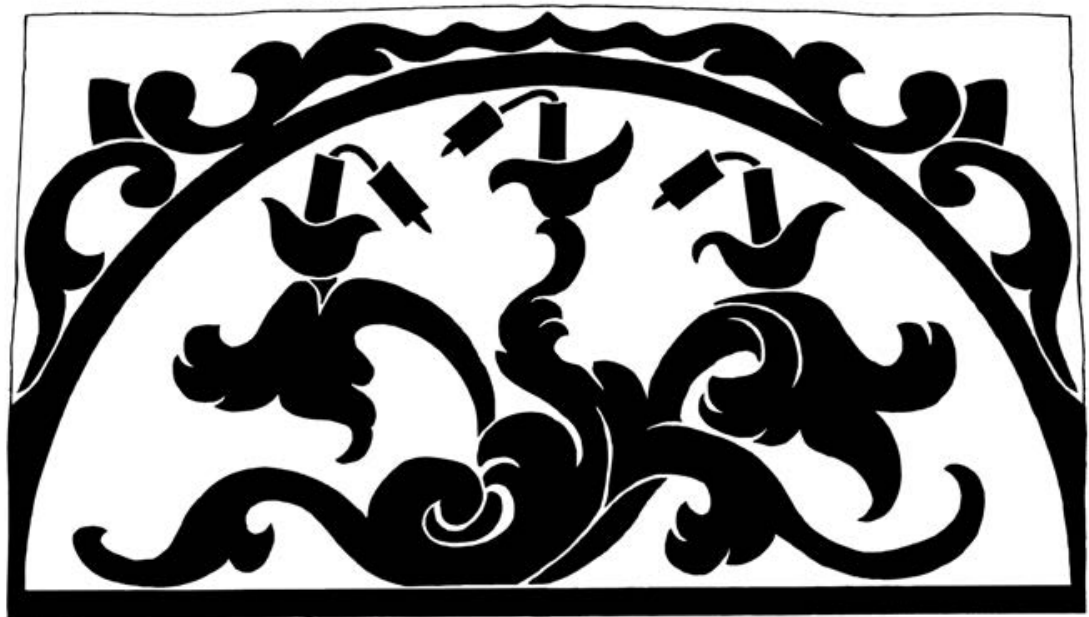

Il. 20. Sara Doba córka Aharona Lejba, żona Cwiego Hirsza Grachmana, zm. 1854, Warszawa 


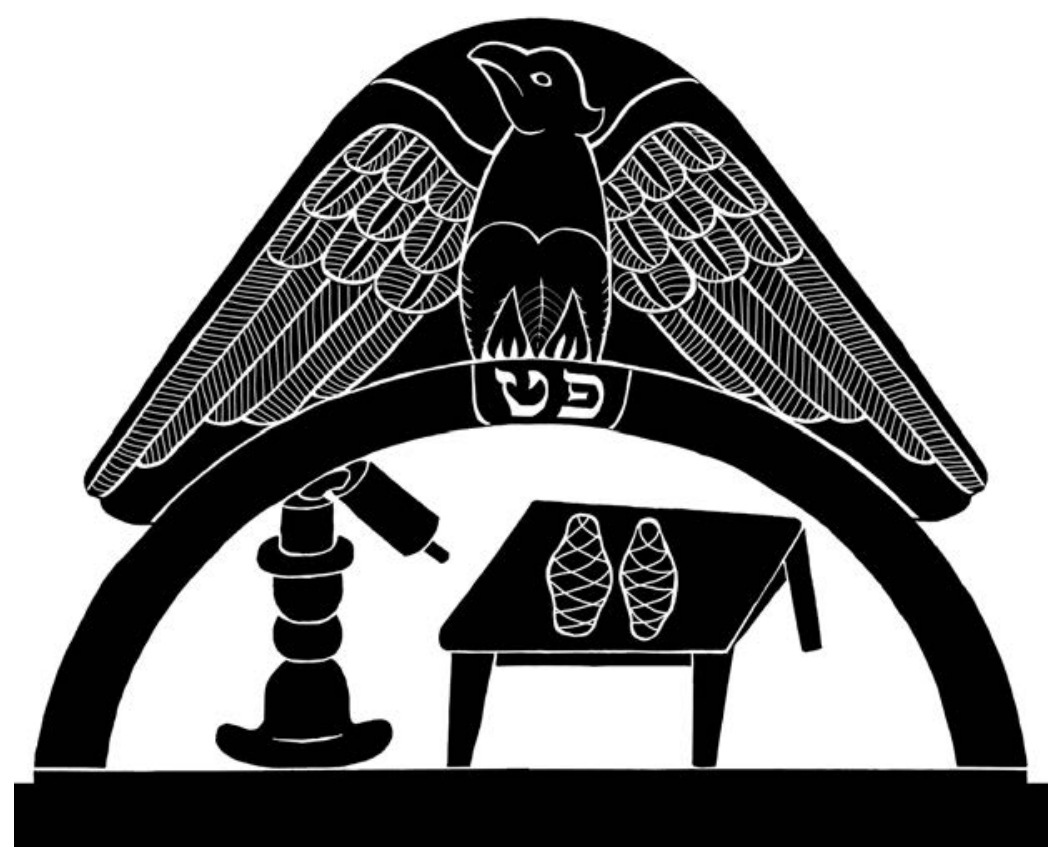

Il. 21. Chana córka Zeewa Wolfa, zm. 1862, Radomsko

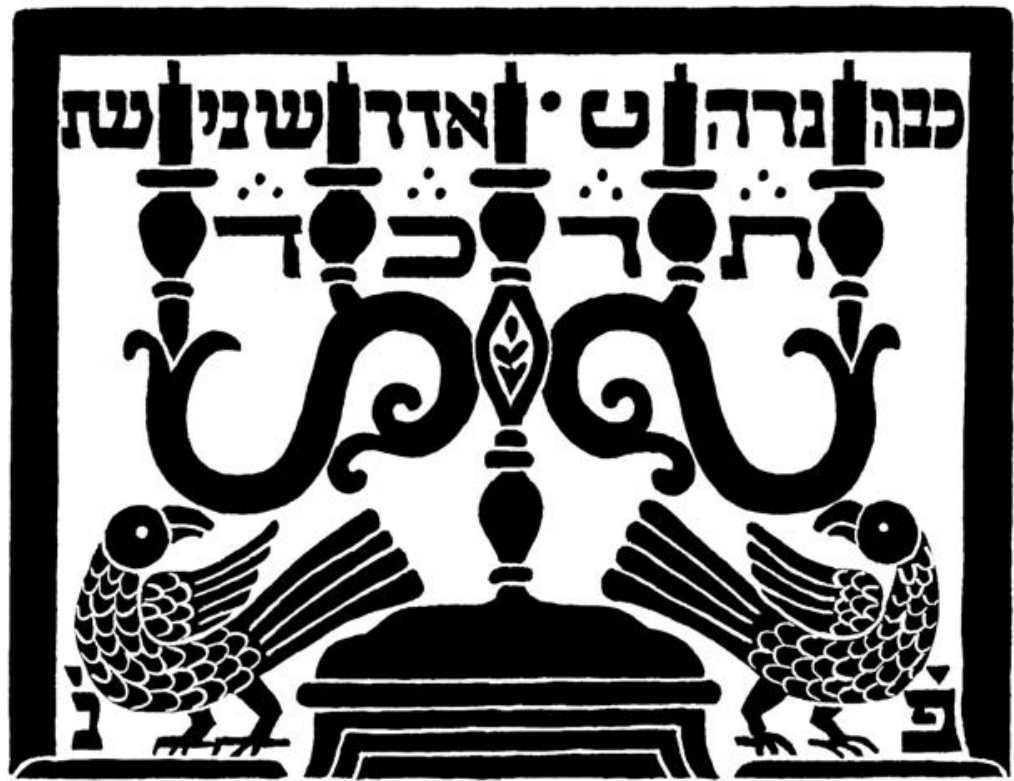

Il. 22. Rachel córka Jehoszuy Szragi, zm. 1864, Lwów 


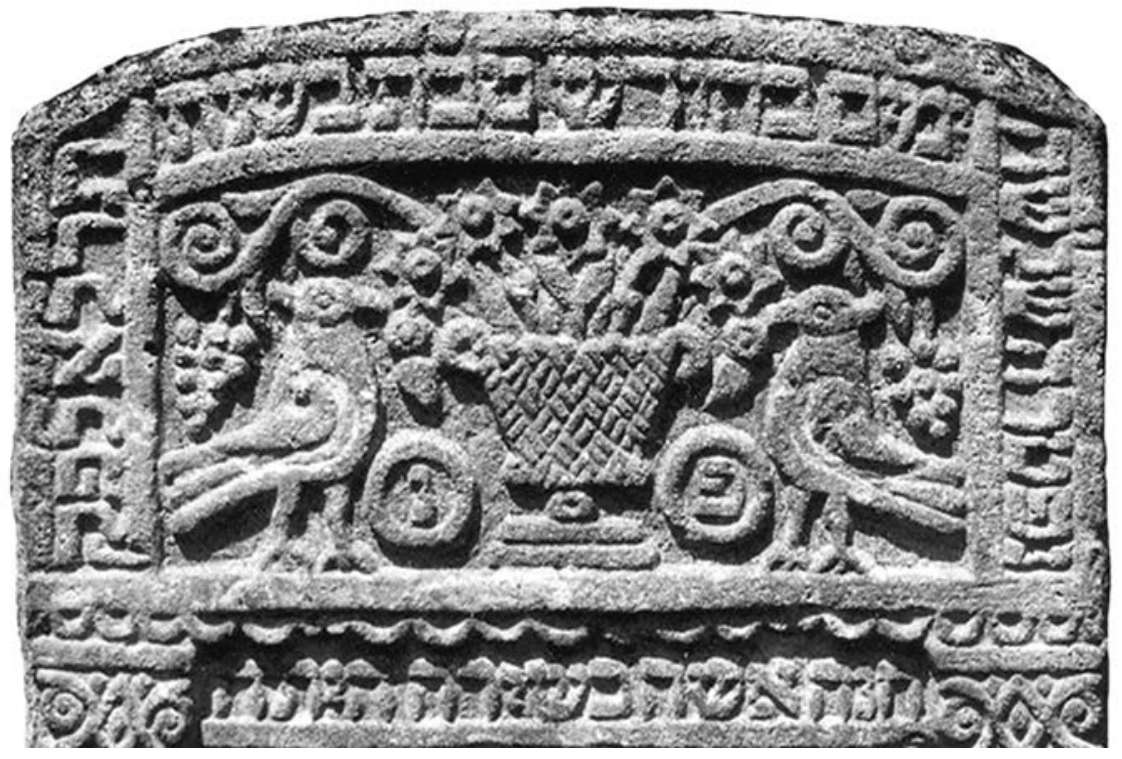

Il. 23. Chana Riwka córka Joela, zm. 1870, Oleszyce

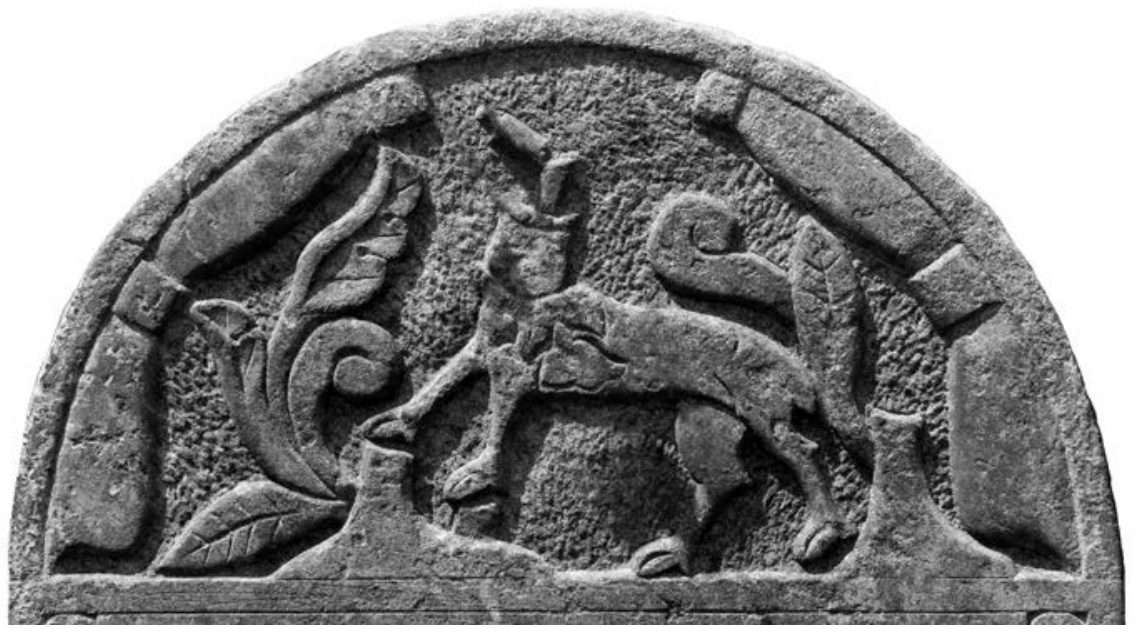

Il. 24. Rachel Malka córka Josefa, zm. 1873, Radomsko 


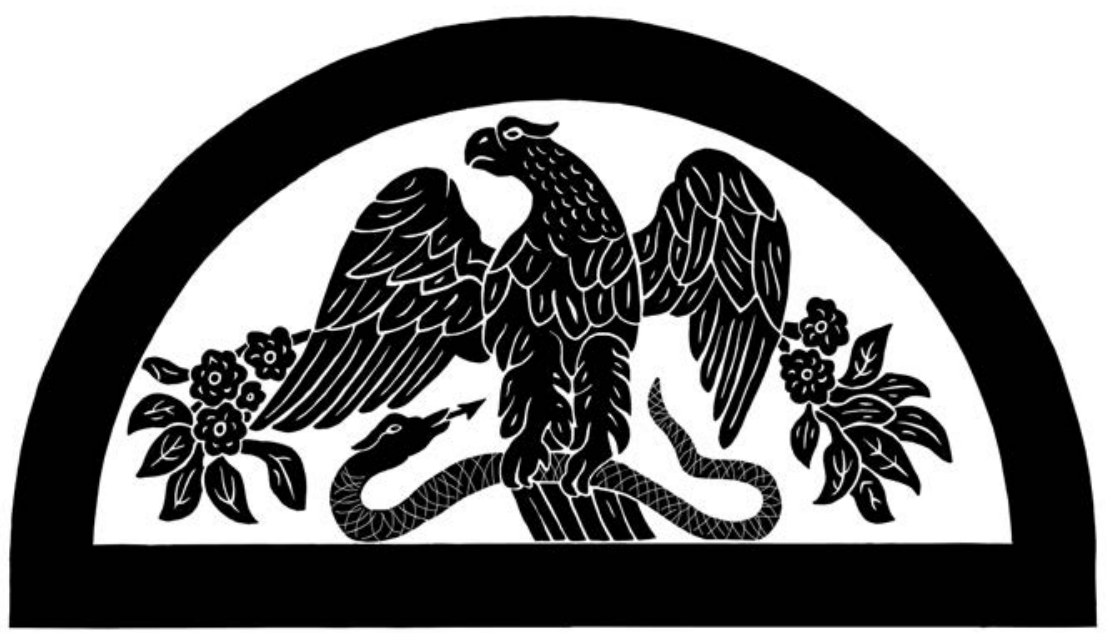

Il. 25. Mirel córka Dawida Grosa, zm. 1884, Warszawa

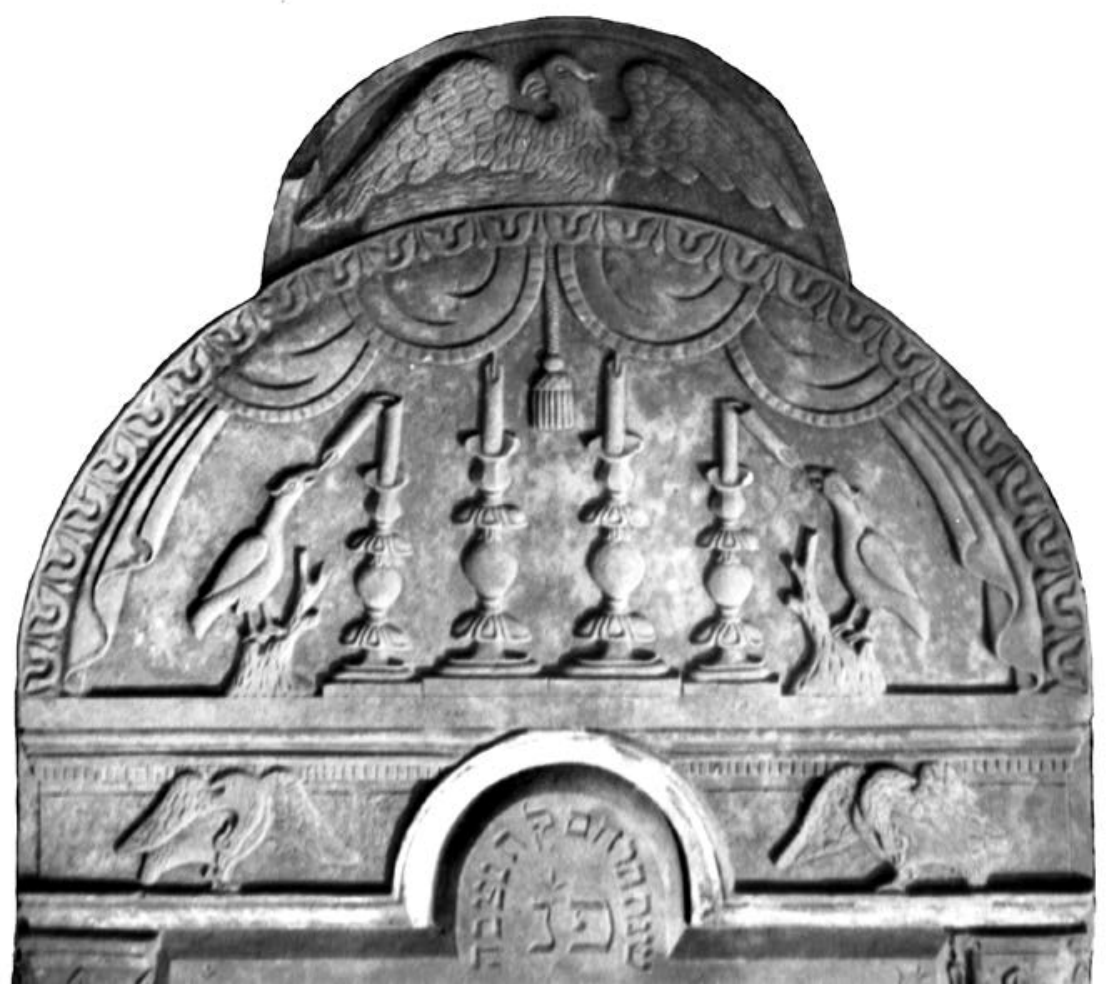

Il. 26. Lea córka Hilela, zm. 1888, Kazimierz Dolny 


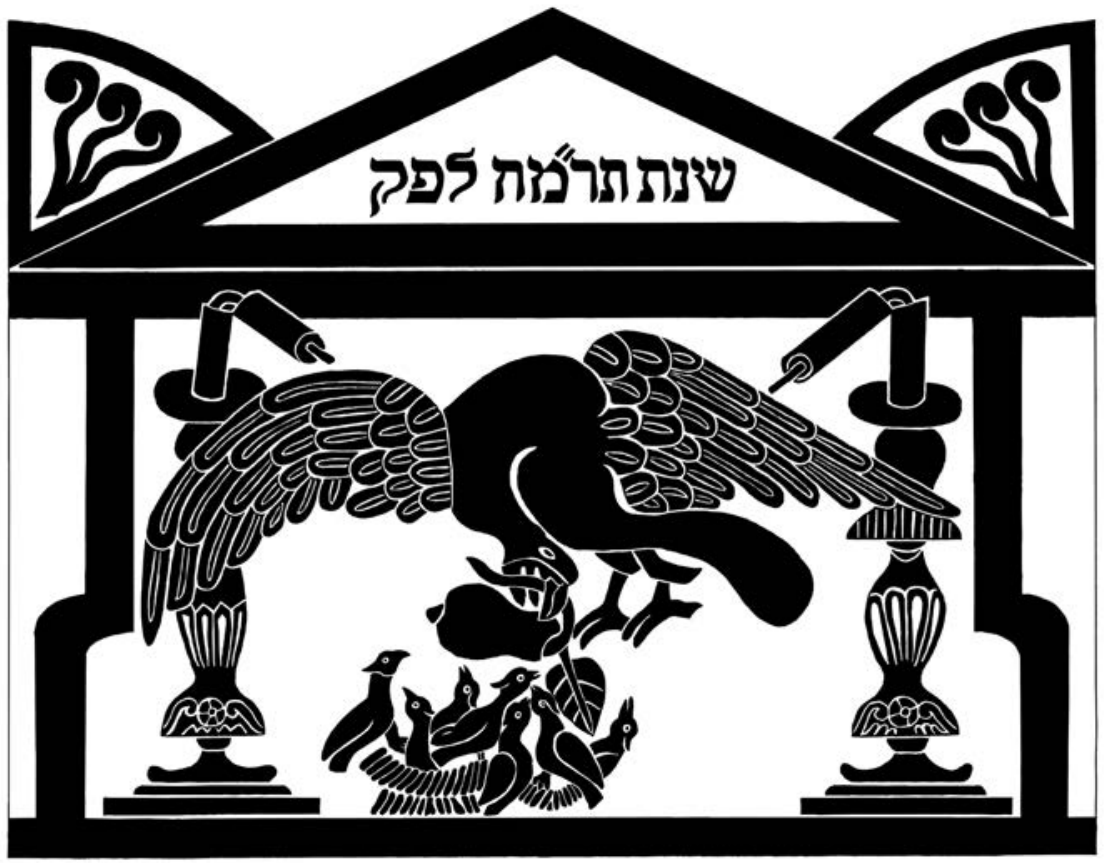

Il. 27. Mirjam córka Szaloma, zm. 1888, Bodzentyn

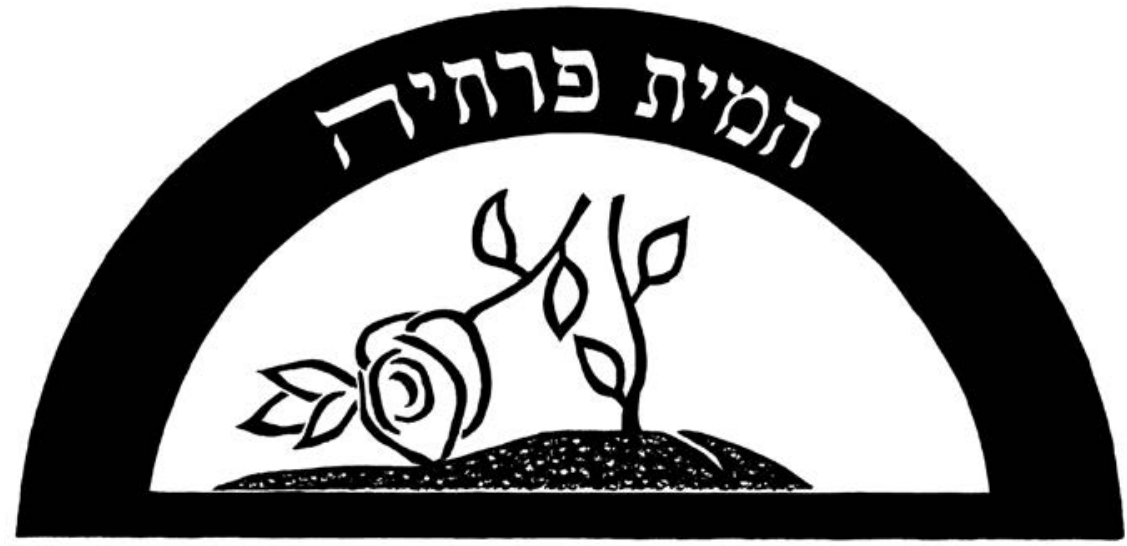

Il. 28. Lea Rozenblum, zm. 1889, Słonim 


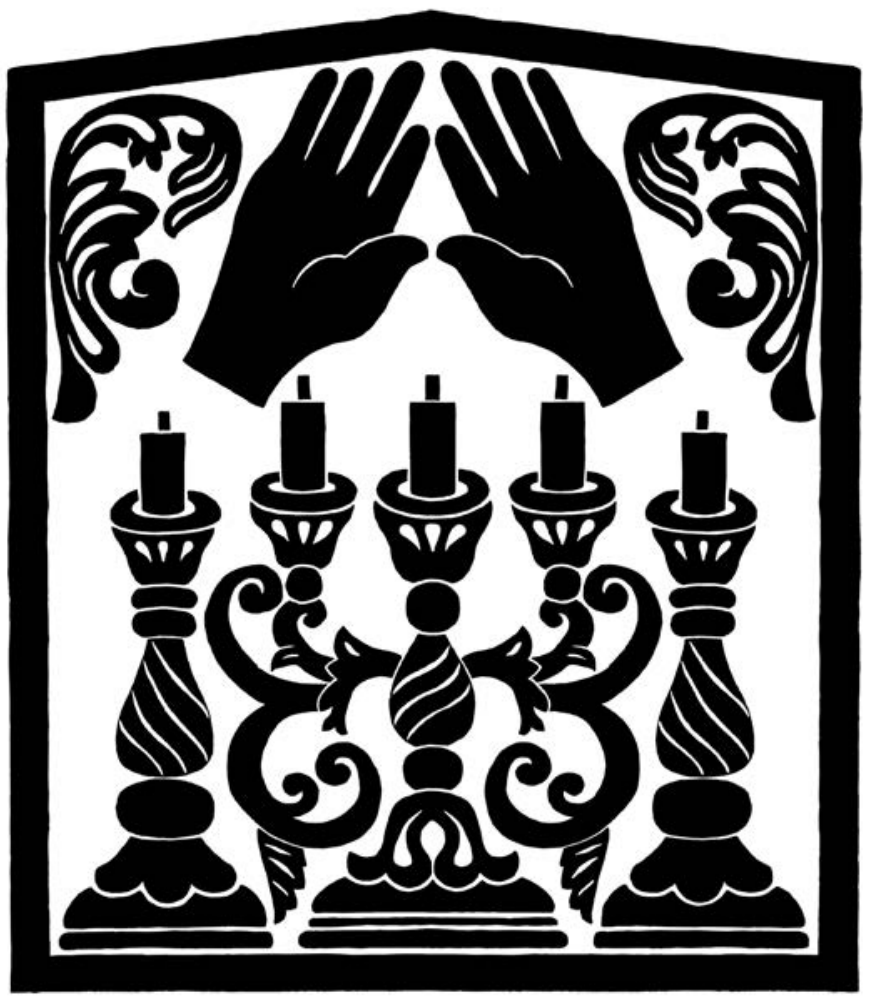

Il. 29. Riwka córka Sinaja, zm. 1891, Śniatyń

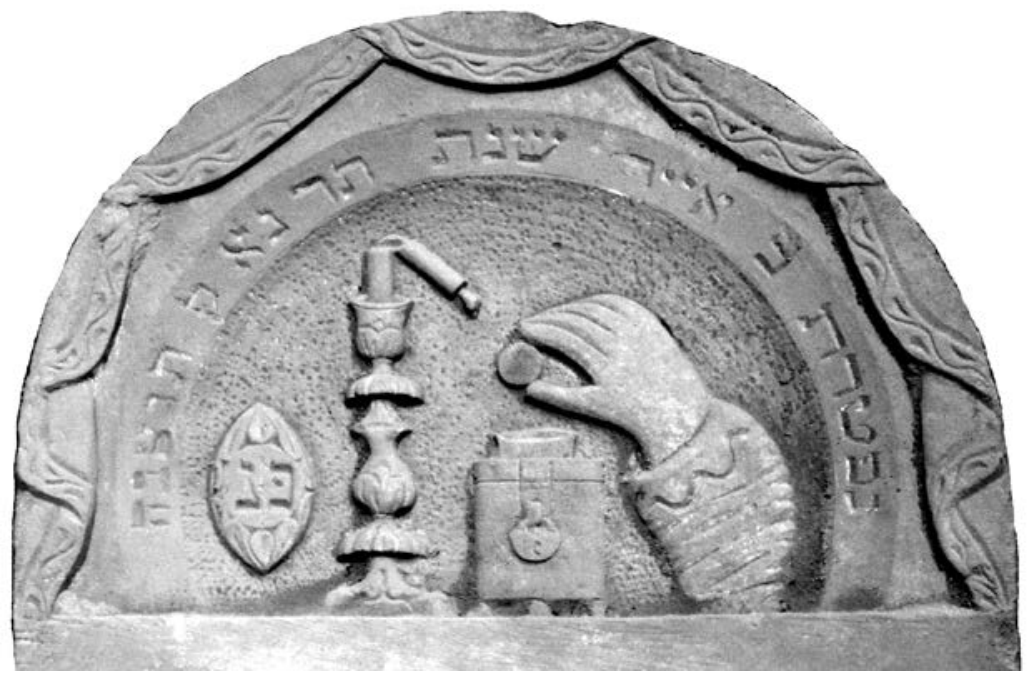

Il. 30. Szejndel Rachma córka Szlomy Josefa, zm. 1891, Markuszów 


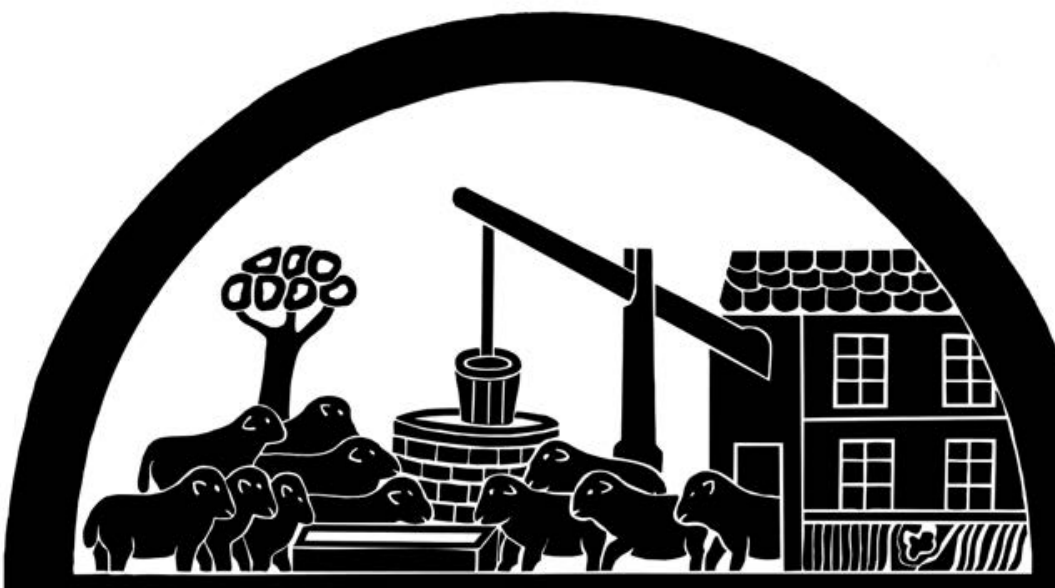

Il. 31. Gitel ..., zm. 1895, Łódź

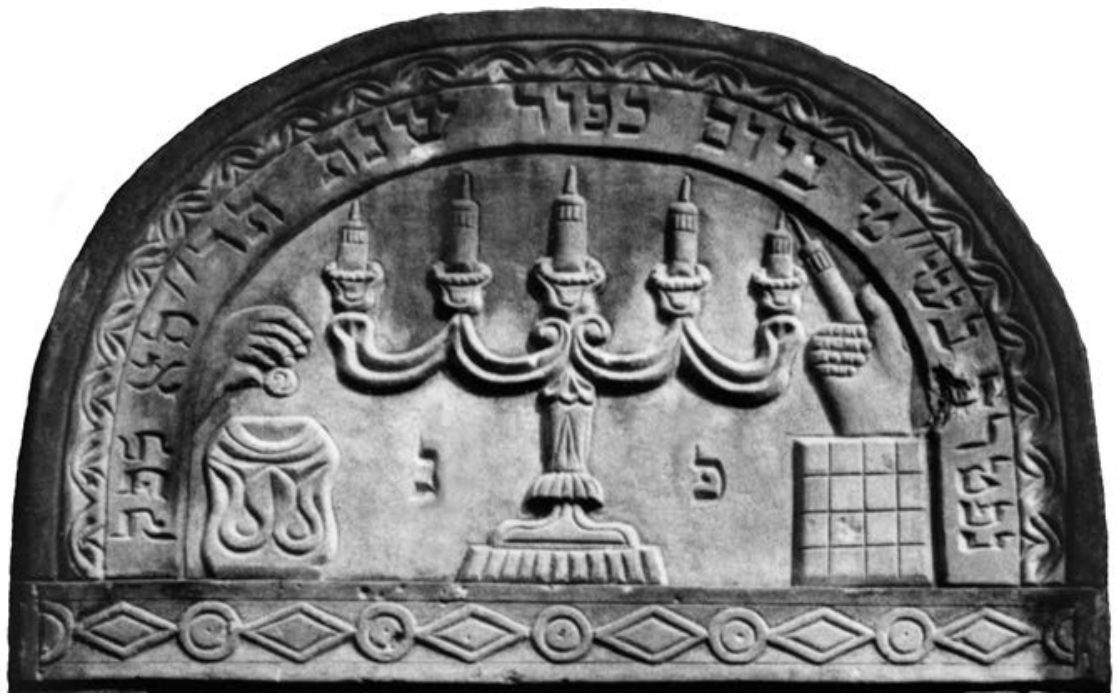

Il. 32. Bejla Cipora córka Jaakowa, zm. 1900, Kazimierz Dolny 


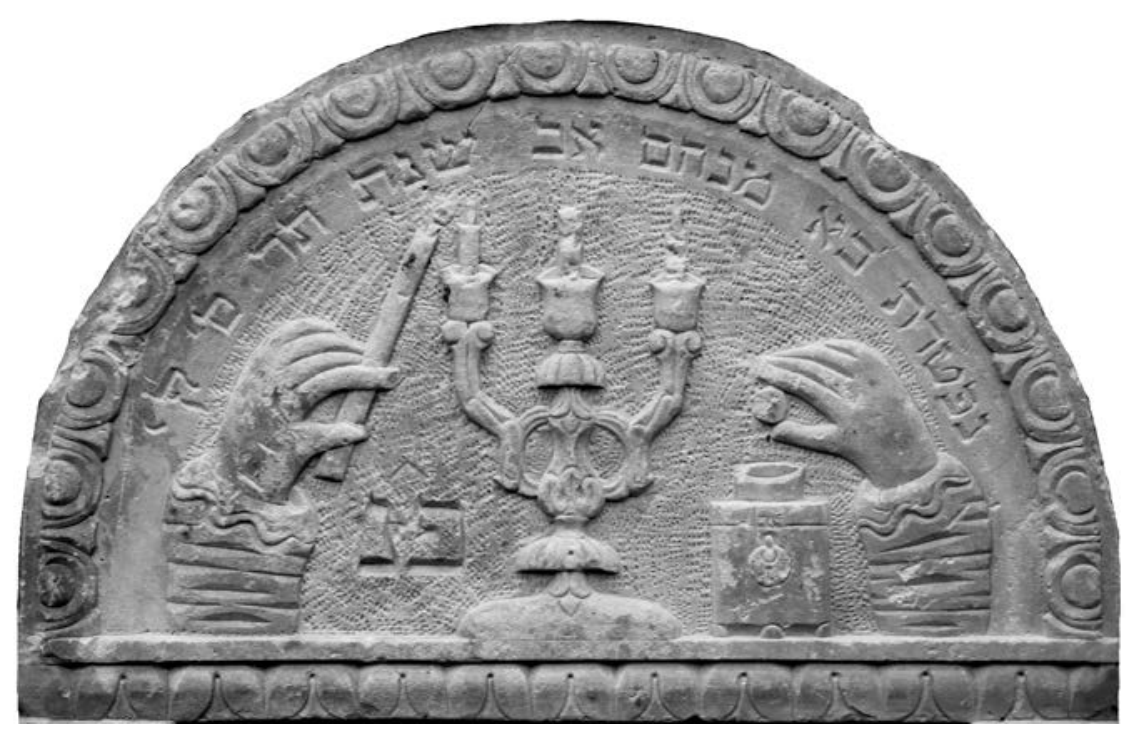

Il. 33. Lea Tema córka Moszego Jechiela, zm. 1900, Kurów

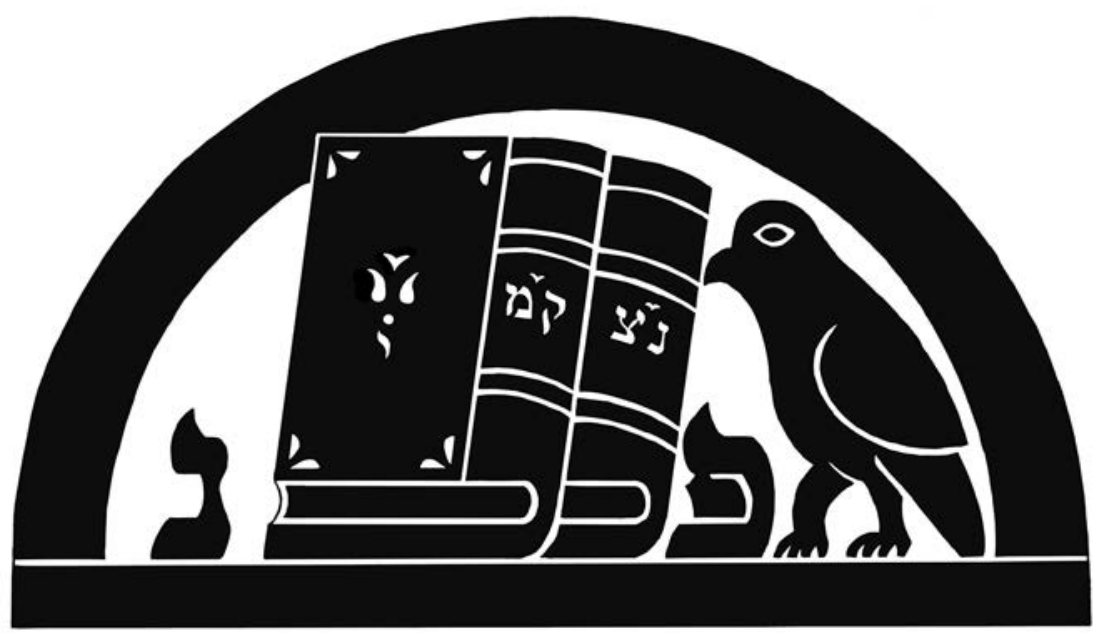

Il. 34. NN kobieta, ok. 1900, Hrubieszów 


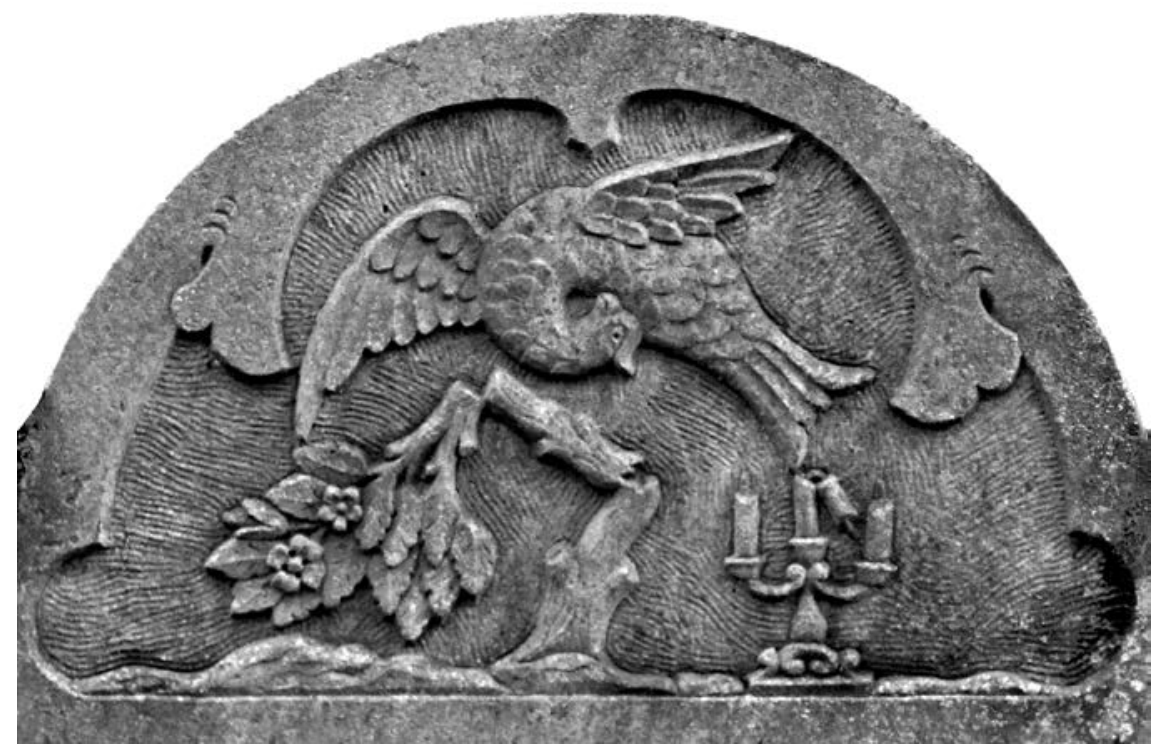

Il. 35. Bejla Mirel Szefner, po 1900, Łódź

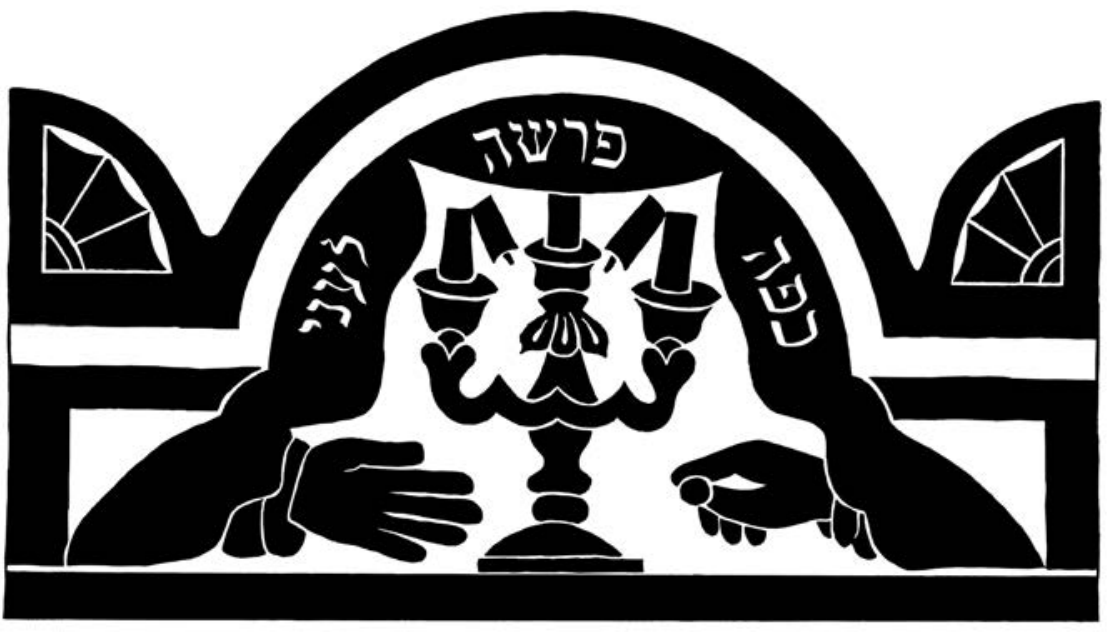

Il. 36. Riwka córka Josefa, po 1900, Kielce 


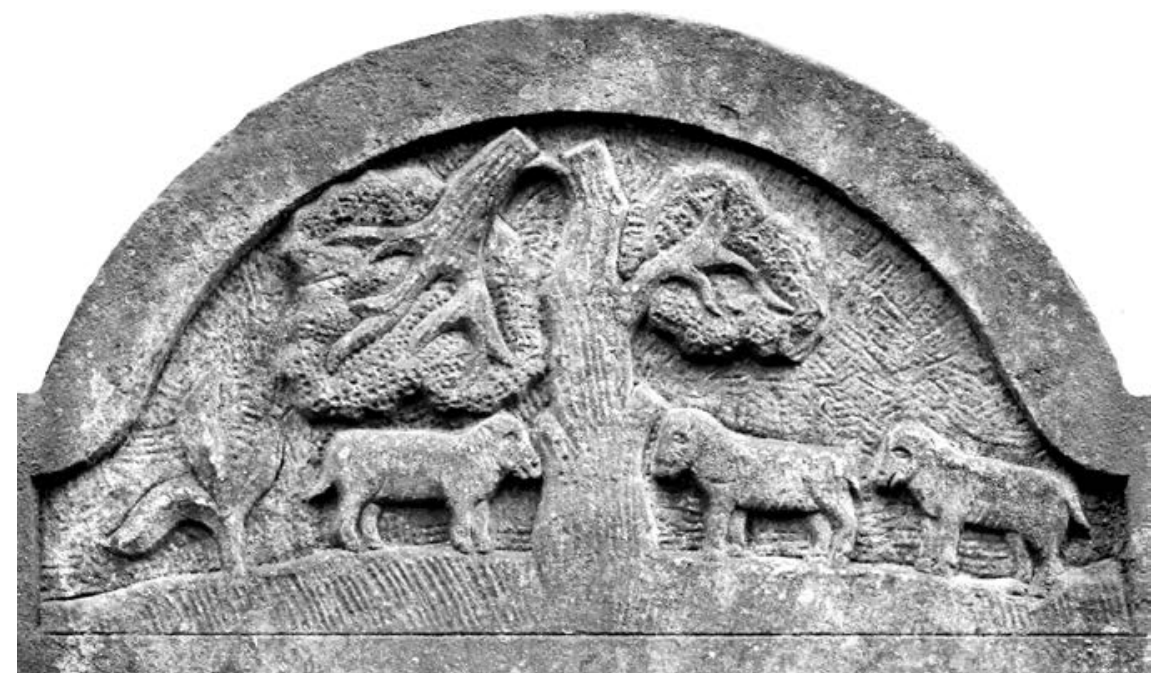

Il. 37. Chana Mirjam Bursztynski, zm. 1905, Łódź

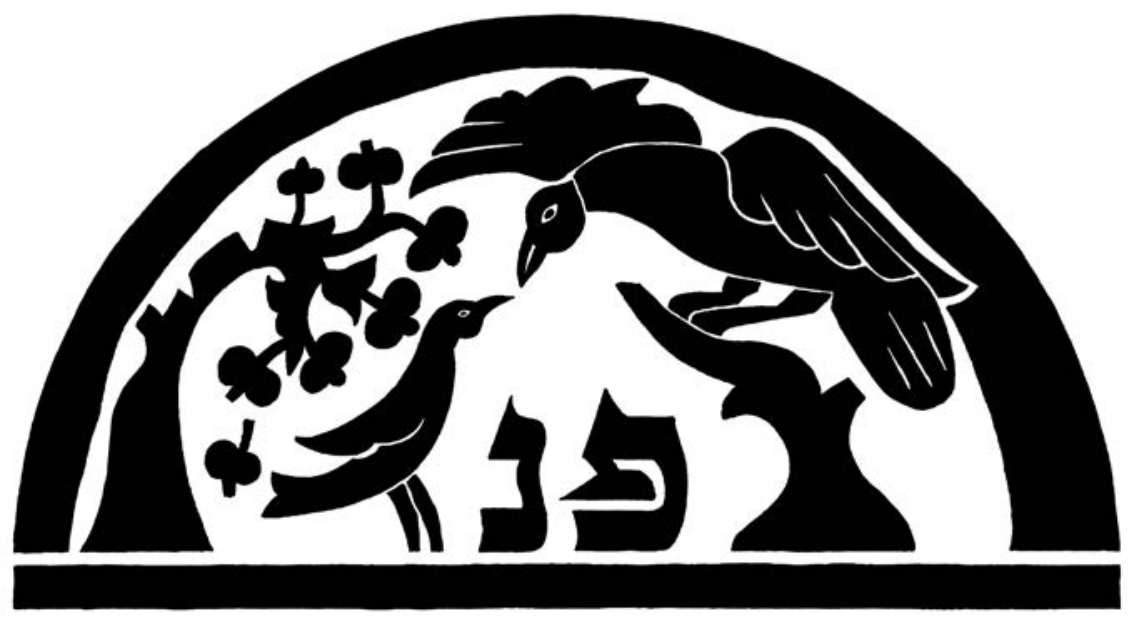

Il. 38. Frajda córka Moszego Cwiego i chłopczyk, zm. 1905, Prużana 


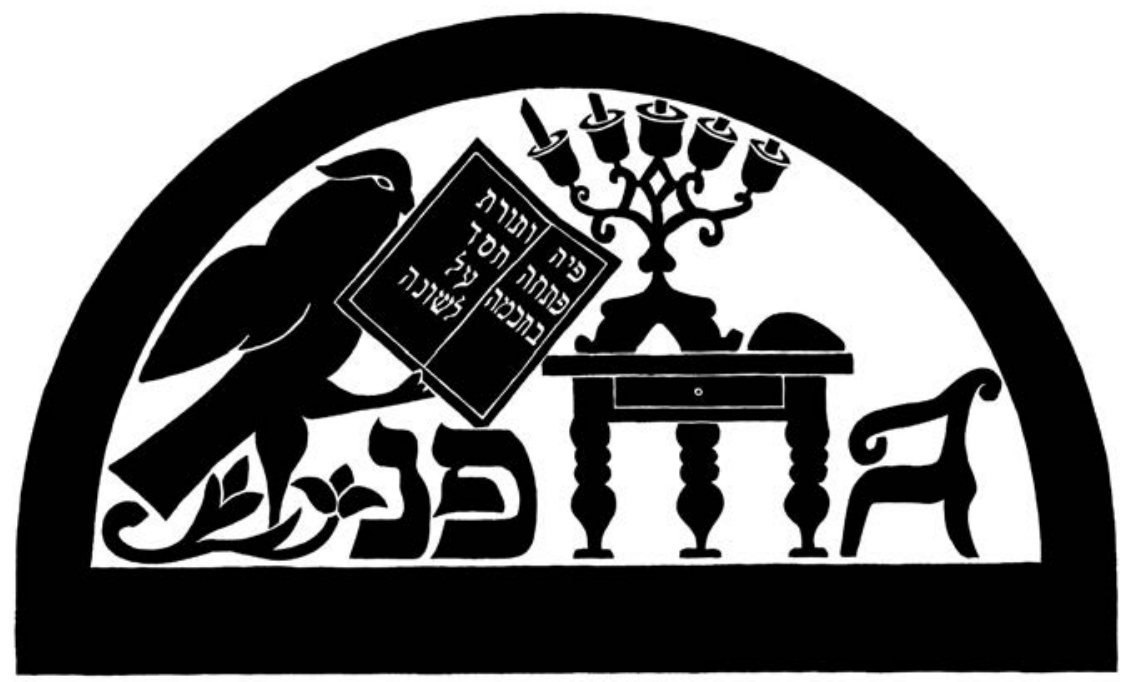

Il. 39. Sara Trajna córka Mordechaja, żona Noacha, zm. 1906, Horodyszcze

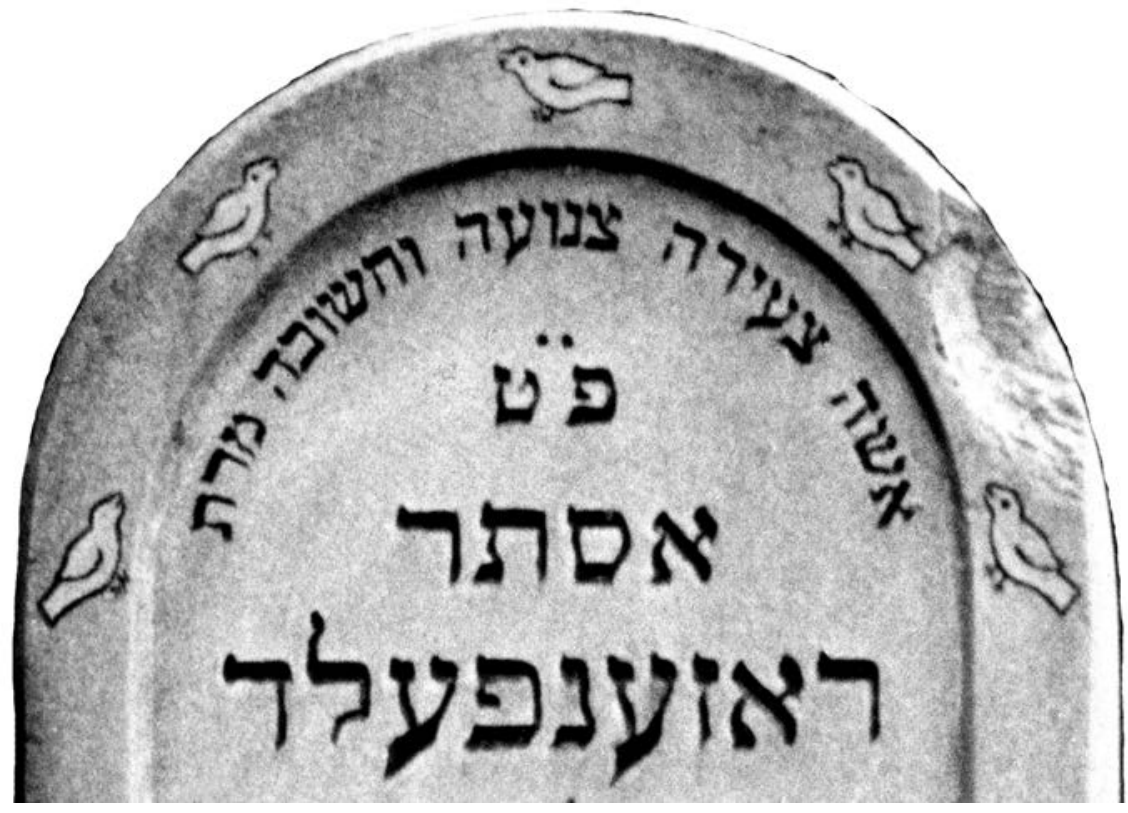

Il. 40. Ester Rozenfeld, zm. 1907, Kraków 


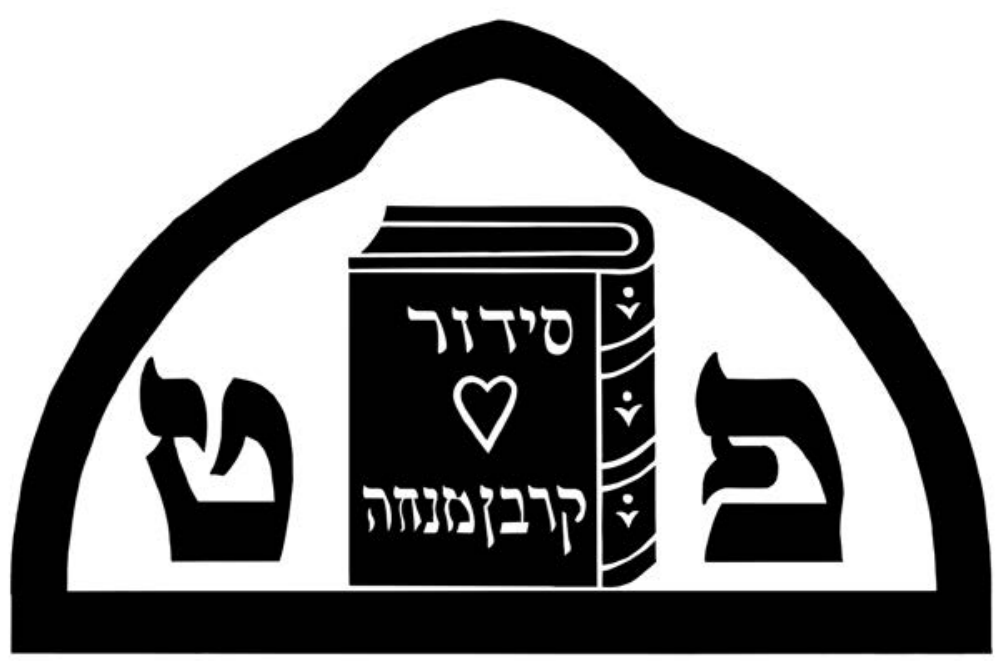

Il. 41. NN kobieta, ok. 1910, Pilica

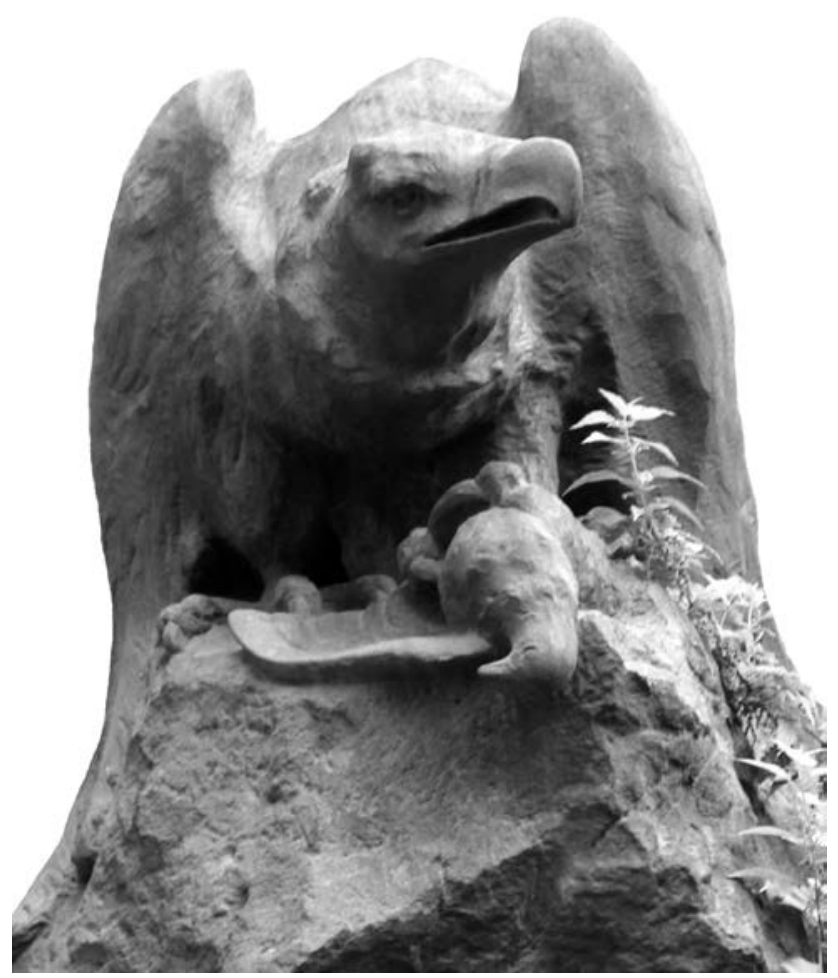

Il. 42. Gustawa Ałapinowa, zm. 1912, Warszawa 


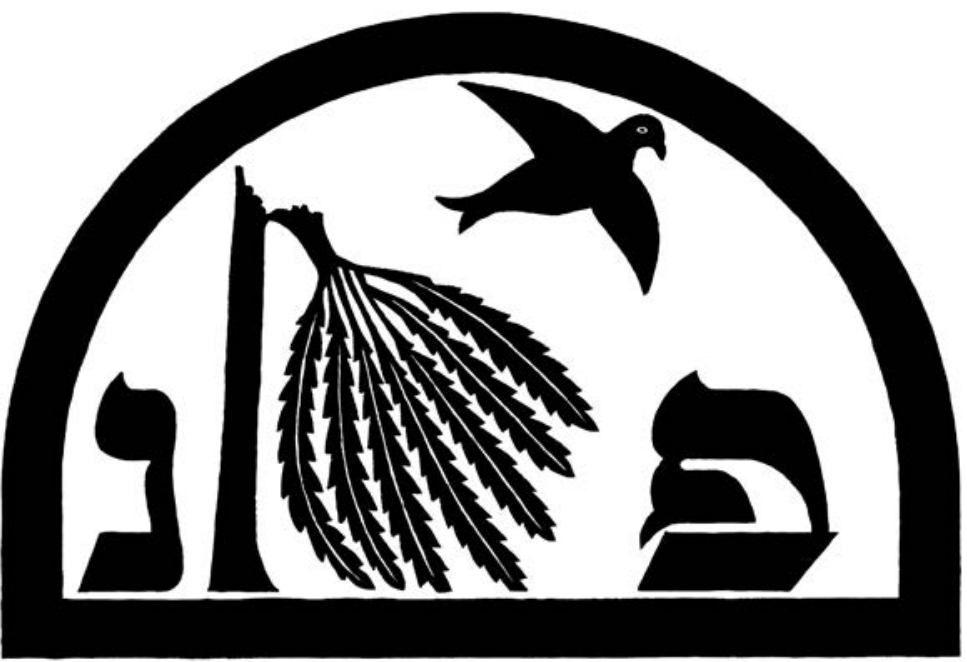

Il. 43. Cipora Fajgel Rozensztejn, zm. 1914, Prużana

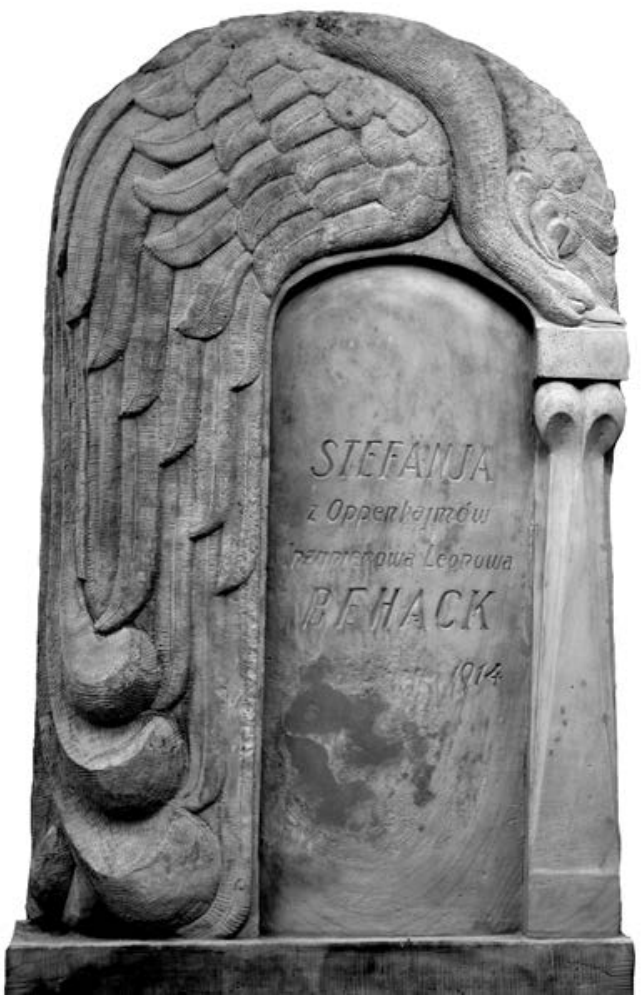

Il. 44. Stefanja z Oppenhajmów Leonowa Behack, zm. 1914, Warszawa 


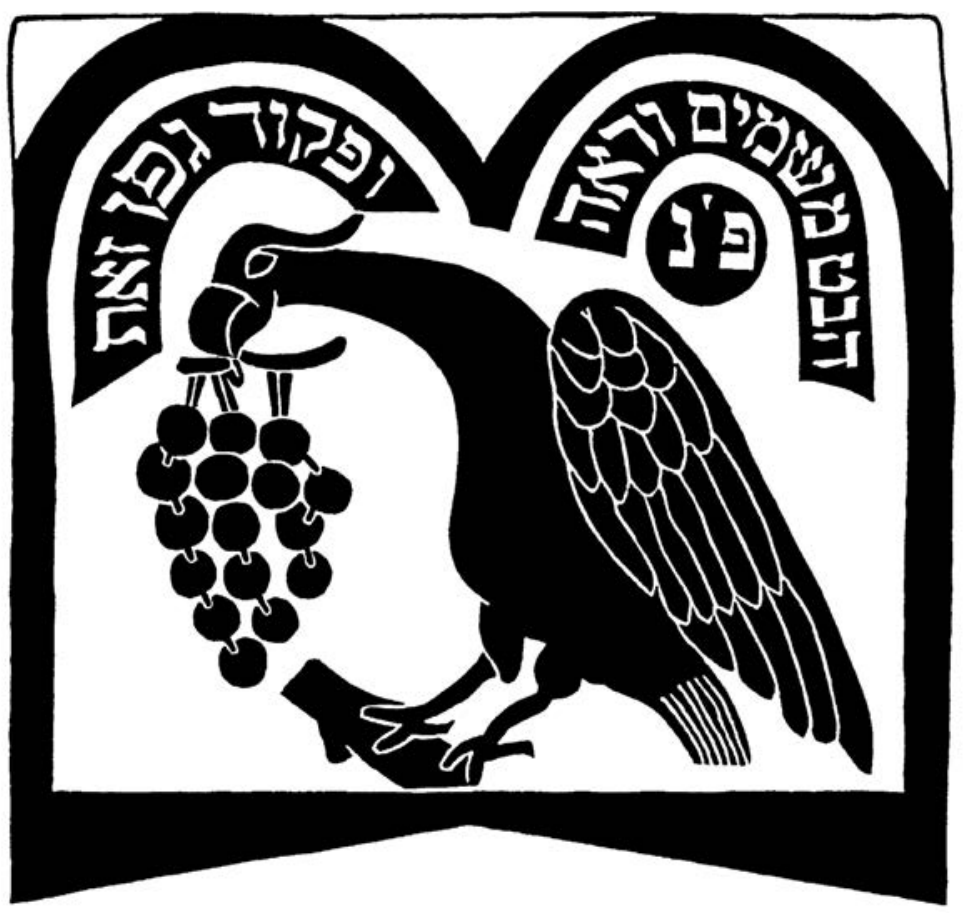

Il. 45. Krejndel córka Cwiego, zm. 1920, Kielce

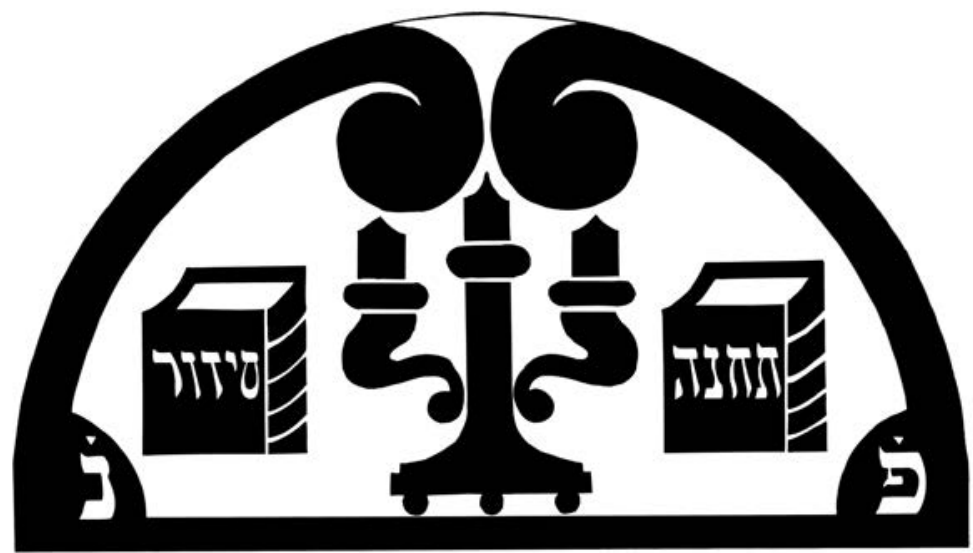

Il. 46. NN kobieta, ok. 1920, Wyszków 


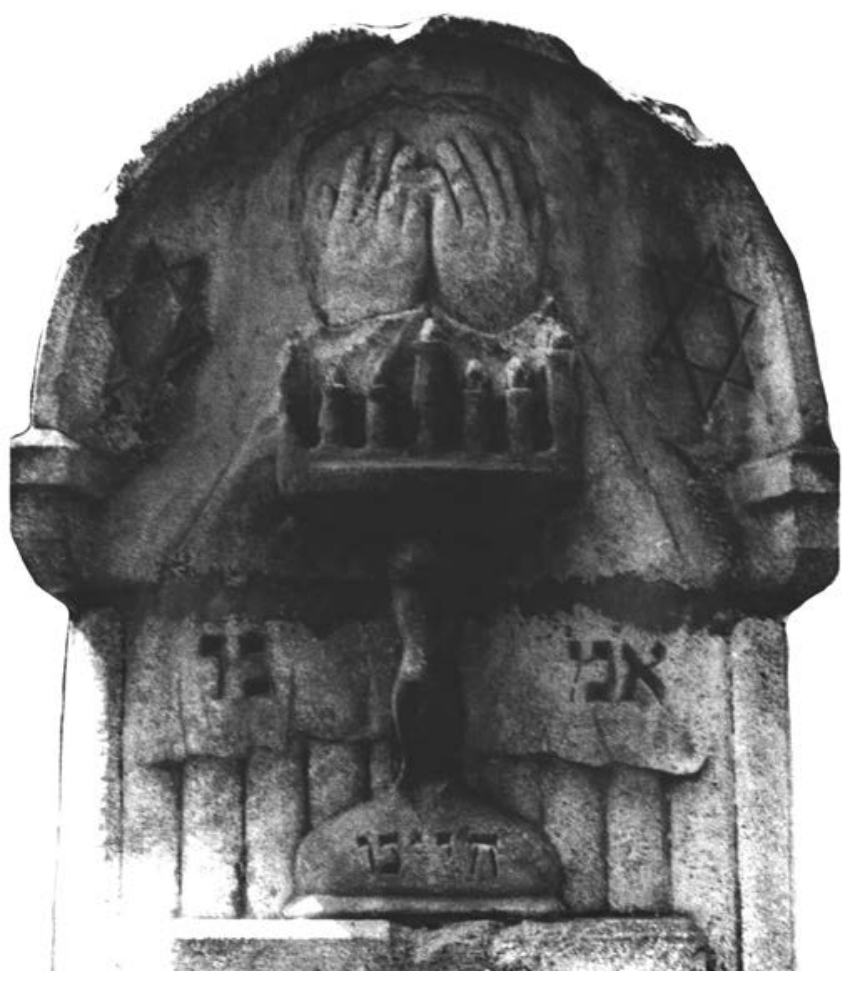

Il. 47. Chaja ..., zm. 1921, Śniatyń

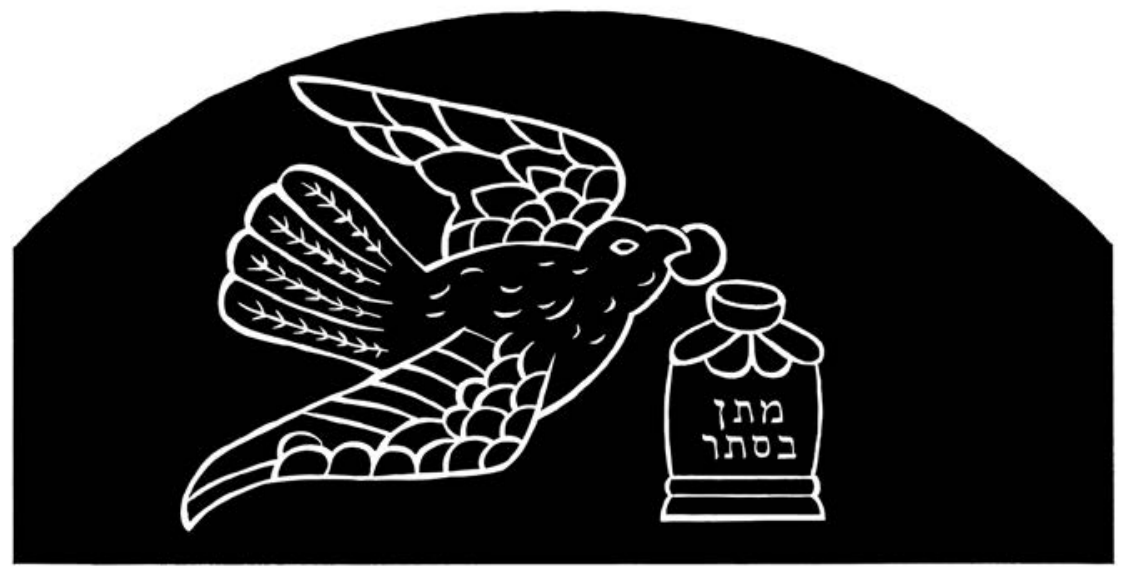

Il. 48. Perel Manela córka Awrahama Aby ha-Lewiego, zm. 1926, Kielce 


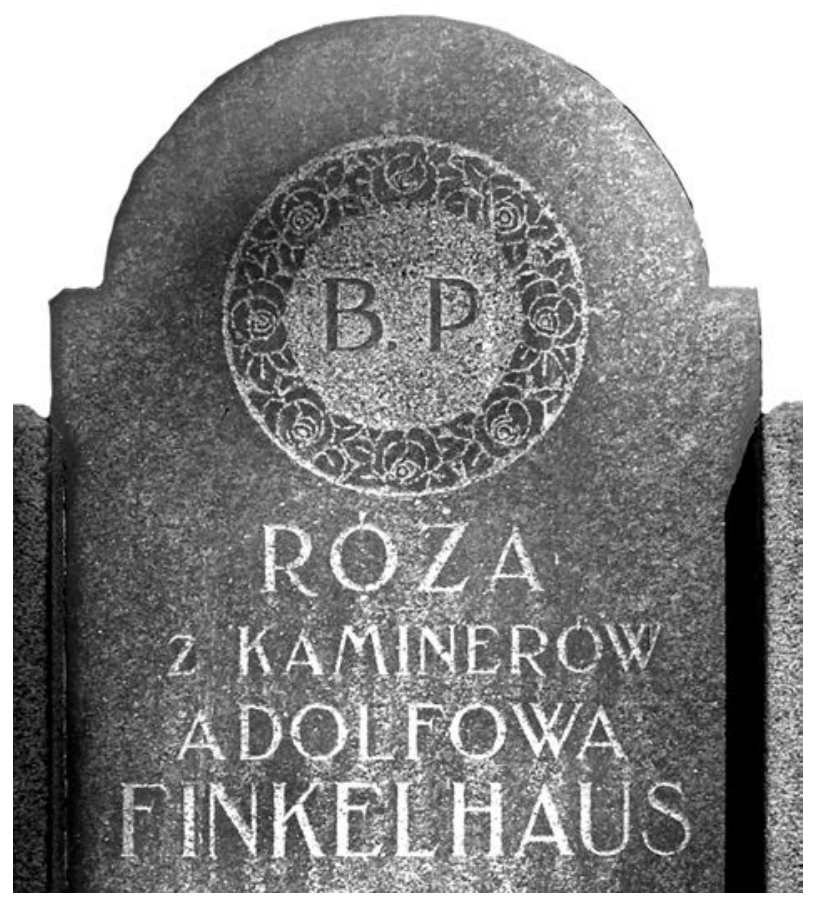

Il. 49. Róża z Kaminerów Adolfowa Finkelhaus, zm. 1926, Warszawa

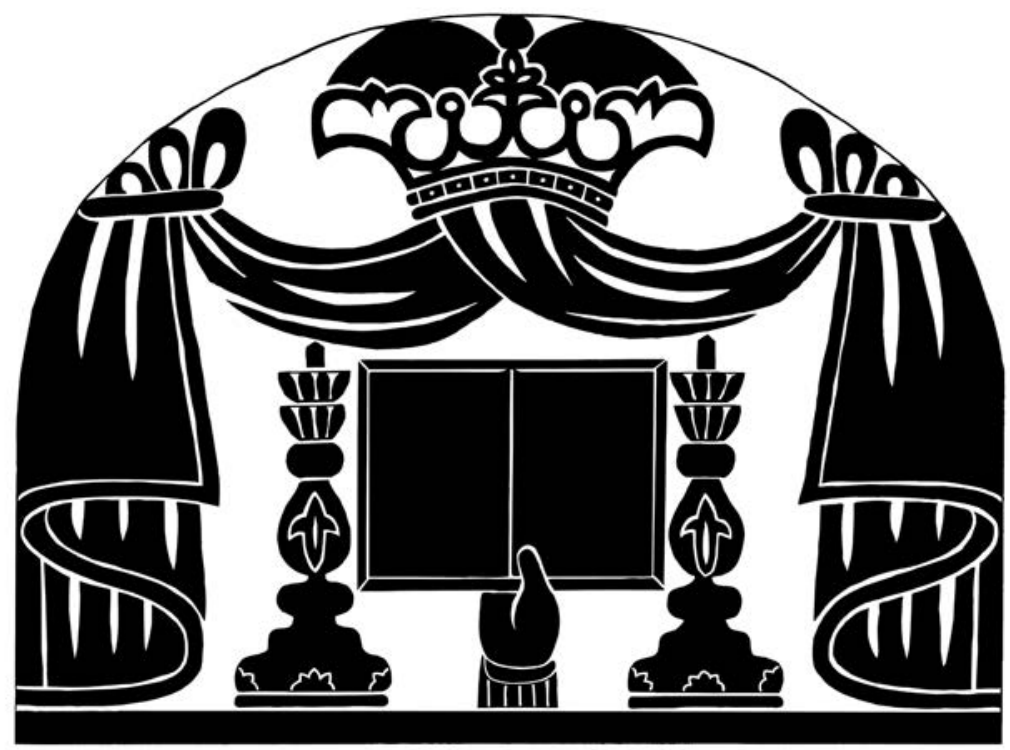

Il. 50. Chana Hinda córka Szlomy, zm. 1927, Ostrowiec Świętokrzyski 


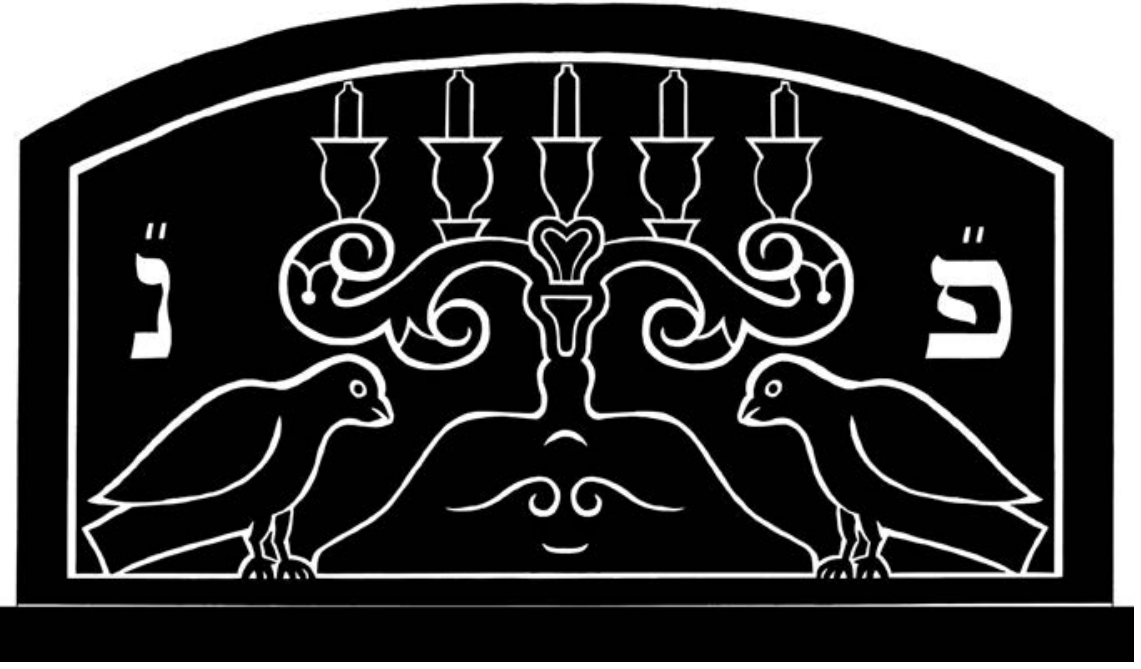

Il. 51. Chaja córka Jehoszuy, zm. 1928, Lutowiska

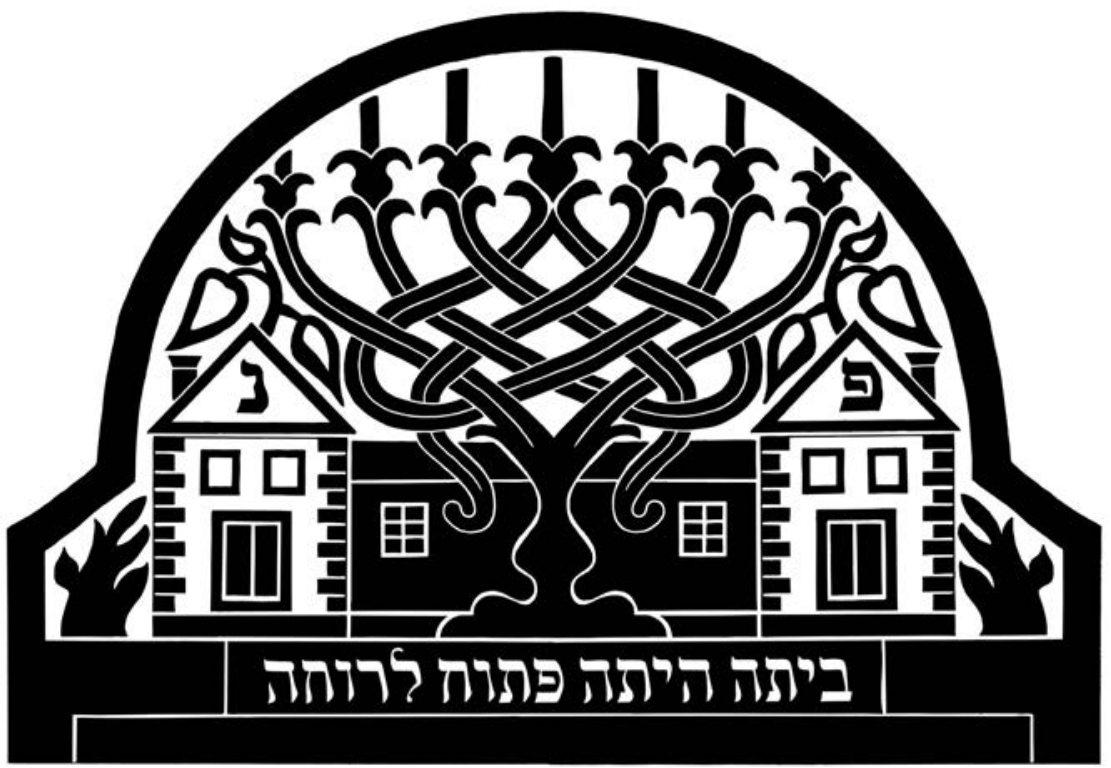

Il. 52. Rachel córka Natana Cwiego, zm. 1930, Lesko 


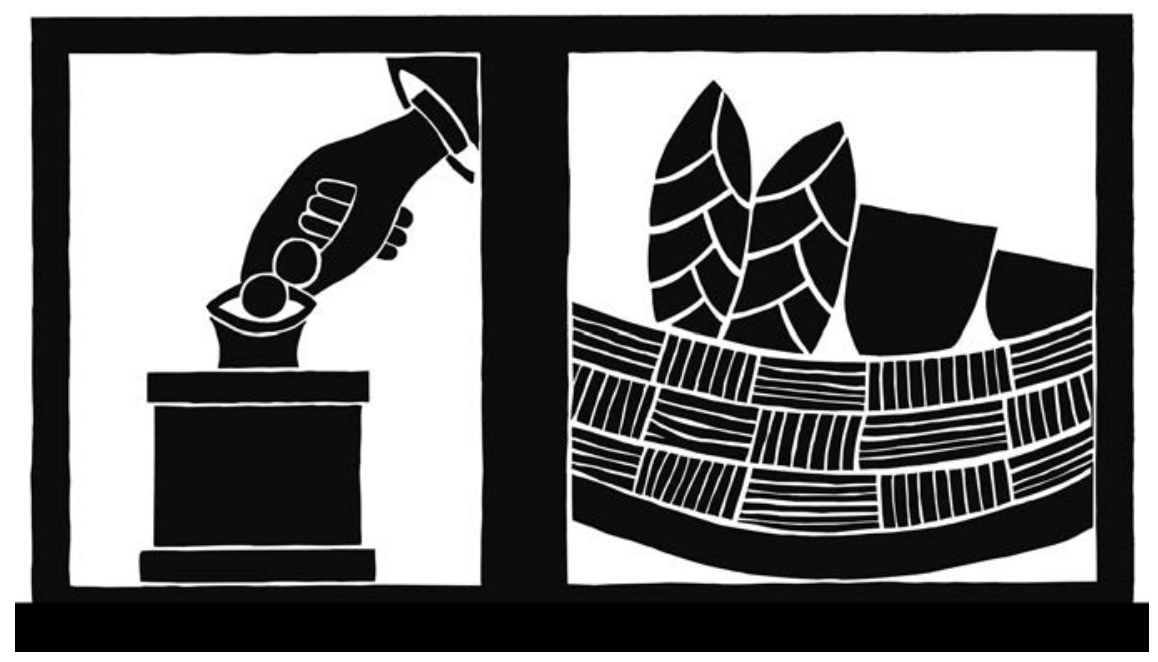

Il. 53. Ester córka Jicchaka Moszego, żona Eleazara Chajima, zm. 1931, Szydłowiec

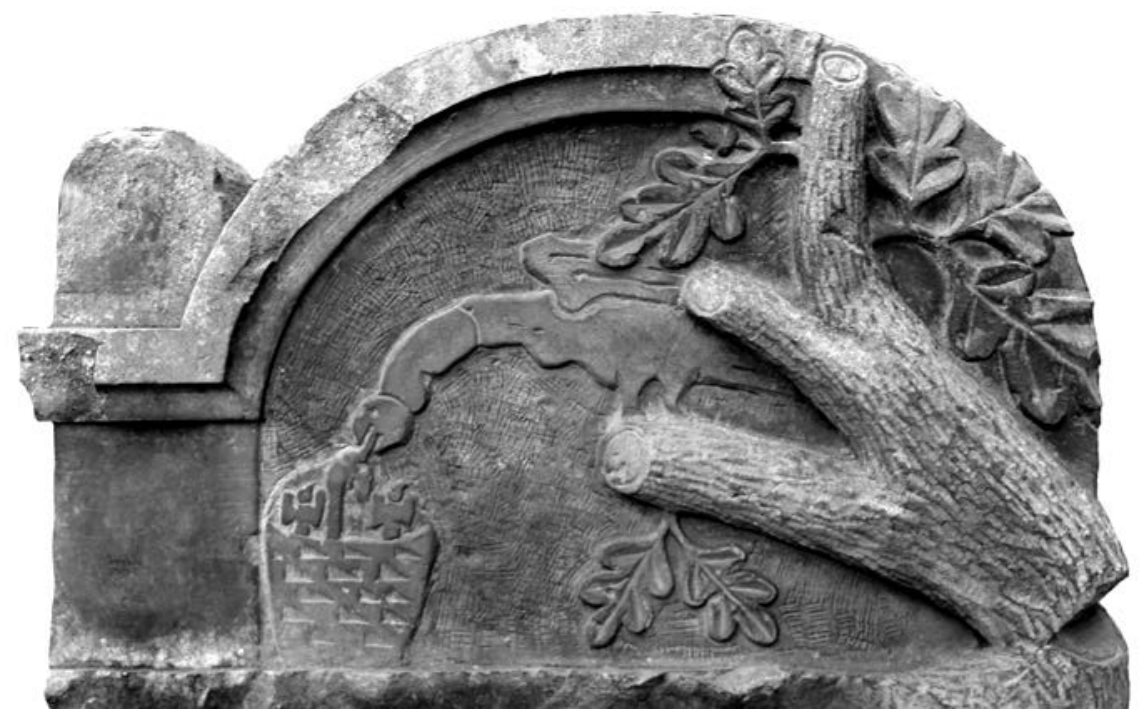

Il. 54. Bejla Obcas córka Zusmana, zm. 1937, Szydłowiec 


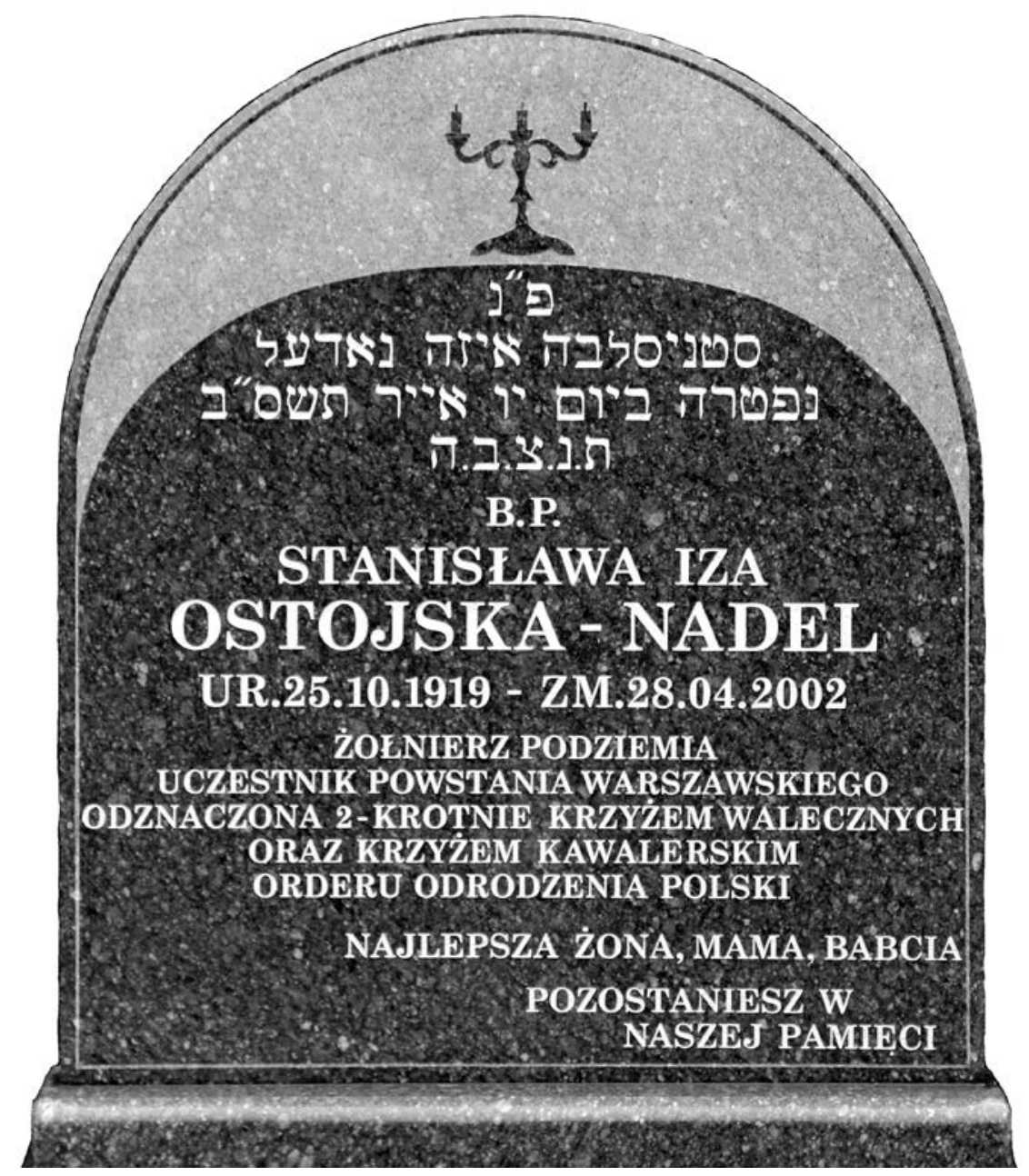

Il. 55. Stanisława Iza Ostojska-Nadel, zm. 2002, Łódź 


\section{Bibliografia}

\section{1. Źródła archiwalne}

Archiwum Uniwersytetu Wrocławskiego

Woronczak Jan Paweł, Cmentarz żydowski w Kromołowie jako tekst kultury, Wrocław 1999 (mps rozprawy doktorskiej pod kierunkiem prof. Jacka Kolbuszewskiego, Uniwersytet Wrocławski).

\section{2. Źródła opublikowane}

Bin Gorion Micha Josef, Żydowskie legendy biblijne, tłum. Robert Stiller, Gdynia 1996.

Exhibition of Tombstones of the Jewish Cemetery in Szydlowiec (Poland). Graphic prints by Jacek Antoni Zielinski and Lucyna Krakowska, Museum of Ethnography and Folklore, December 1963 - February 1964, Tel Aviv 1963.

Fabryka wyrobów srebrnych i platerowanych Józef Fraget, [oferta wyrobów], Warszawa 1932.

Jak modla się Żydzi. Antologia modlitw, oprac. Maciej Tomal, tłum. Ewa Gordon i Maciej Tomal, Warszawa 2000.

Judaika w zbiorach Muzeum Narodowego w Krakowie. Rzemiosto artystyczne, druki i rękopisy, monety i medale, varia, oprac. Stanisława Odrzywolska, Monika Paś i in., Kraków 2018.

Judaika w zbiorach Muzeum Narodowego w Warszawie, oprac. Ewa Martyna, Warszawa 1993.

Langer Jiři, 9 bram do tajemnic chasydów, tłum. Anna Godlewska, Kraków 1988. Levy Arthur, Jüdische Grabmalkunst in Osteuropa: Eine Sammlung, Berlin 1924.

Lilientalowa Regina, Życie pozagrobowe $i$ świat przyszły $w$ wyobrażeniu ludu żydowskiego, „Lud” 8 (1902).

Miszna Naszim (Kobiety), wstęp, tłum. i oprac. Roman Marcinkowski, WarszawaBellerive-sur-Allier 2016.

Sefaria: A Living Library of Jewish Texts, https:/www.sefaria.org/?home.

Slonik Binjamin Aharon ben Awraham, Sejder micwes noszim; ejn szejn frauen bichlejn, Kraków 1577.

Suchestow Gawriel, Macewet kodesz hu zichron cadikim, z. 2, Lemberg 1864. Tarjag micwot. 613 przykazań judaizmu, tłum. Ewa Gordon, Kraków 2000. Tow. Akc. Norblin, Br. Buch i T. Werner, [oferta wyrobów], Warszawa 1897.

\section{Opracowania}

Bałaban Majer, Historia i literatura żydowska ze szczególnym uwzględnieniem historii Żydów w Polsce, t. 3: Od wygnania Żydów z Hiszpanii do rewolucji francuskiej (od Zygmunta Starego do trzeciego rozbioru Polski), Lwów 1925.

Bałaban Majer, Żydzi lwowscy na przełomie XVI i XVII w., Lwów 1906.

Brocke Michael, The Lilies of Worms, „Zutot” 8 (2011). 
Elon Menachem, Woman: The Judicial Perspective: Women and the Israeli Courts, [w:] Encyclopaedia Judaica. Second Edition, red. Fred Skolnik, Michael Berenbaum, Detroit 2007, t. 21.

Ginzberg Louis, The Legends of the Jews, t. 3: Bible Times and Characters from the Exodus to the Death of Moses, Philadelphia 1909.

Goldberg-Mulkiewicz Olga, Obrzędy żałobne i pogrzebowe Żydów polskich, „Polska Sztuka Ludowa” 40 (1986), nr 1-2.

Goodenough Erwin Ramsey, Jewish Symbols in the Greco-Roman Period, t. 7, New York 1958.

Hońdo Leszek, Stary żydowski cmentarz w Krakowie. Historia cmentarza. Analiza hebrajskich inskrypcji, Kraków 1999.

Jerkiewicz Lidia, Rola zogerek $w$ tradycyjnej społeczności żydowskiej. Rekonesans badawczy, [w:] Nieme dusze? Kobiety w kulturze jidysz, red. Joanna Lisek, Wrocław 2010.

Krajewska Monika, A Tribe of Stones: Jewish Cemeteries in Poland, wstęp Rafael Scharf, Warsaw 1993.

Krajewska Monika, Cmentarze żydowskie w Polsce: nagrobki i epitafia, „Polska Sztuka Ludowa” 43 (1989), nr 1-2.

Krajewska Monika, Symbolika płaskorzeźb na cmentarzach żydowskich w Polsce, „Polska Sztuka Ludowa” 43 (1989), nr 1-2.

Krzywicka Aneta, Trzciński Andrzej, Technologiczne i formalne cechy nagrobków, [w:] Cmentarze żydowskie w Sandomierzu, red. Piotr Sławiński, Sandomierz 2011.

Levi Giuseppe, Das Buch der jüdischen Weisheit: Parabeln, Legenden und Gedanken aus Talmud und Midrasch, Wien 1921.

Lisek Joanna, Kol isze - głos kobiet w poezji jidysz (od XVI w. do 1939 r.), Sejny 2018.

Oniszczuk Aleksandra, Żydówki w polskiej historii, [w:] Materiały z konferencji „Polsko-żydowskie dziedzictwo Rzeczypospolitej. Wyzwania pamięci i edukacji”, Muzeum Historii Żydów Polskich POLIN, 14-16 listopada 2019, https://polin. $\mathrm{pl} /$ system/files/attachments/Aleksandra\%20Oniszczuk\%20-\%20\%C5\%BByd\%C3\%B3wki\%20w\%20polskiej\%20historii\%20-\%20podsumowanie $\% 20$ wyk\%C5\%82adu.pdf [dostęp: 12 kwietnia 2021].

Piechotka Maria, Piechotka Kazimierz, Bramy nieba. Bóżnice drewniane na ziemiach dawnej Rzeczypospolitej, Warszawa 1996.

Piechotka Maria, Piechotka Kazimierz, Bramy nieba. Bóżnice murowane na ziemiach dawnej Rzeczypospolitej, Warszawa 1999.

Trzciński Andrzej, Aspekty filologiczne inskrypcji, [w:] Cmentarze żydowskie w Sandomierzu, red. Piotr Sławiński, Sandomierz 2011.

Trzciński Andrzej, Cmentarz żydowski w Lesku. Część II - wiek XVIII, Lublin 2020.

Trzciński Andrzej, Ezrat naszim/babiniec - jako przestrzeń rzeczywista, [w:] Nieme dusze? Kobiety w kulturze jidysz, red. Joanna Lisek, Wrocław 2010.

Trzciński Andrzej, Słowne i ikoniczne reprezentacje motywu księgi/książki na nagrobkach żydowskich w Polsce, „Kwartalnik Historii Żydów” 275 (2020), nr 3.

Trzciński Andrzej, Symbole i obrazy. Treści symboliczne przedstawień na nagrobkach żydowskich $w$ Polsce, Lublin 1997. 
Trzciński Andrzej, Świadkiem jest ta stela. Stary cmentarz żydowski w Lublinie, Lublin 2017.

Trzciński Andrzej, This Very Stone Shall Be a Witness: The Jewish Cemetery in Wielkie Oczy, tłum. Marcin Garbowski, New York 2019.

Trzciński Andrzej, Zachowane wystroje malarskie bóżnic w Polsce, „Studia Judaica” 4 (2001), nr 1-2 (7-8).

Trzciński Andrzej, „Zaszło jego słońce w południe”. Słowne i ikoniczne obrazowanie śmierci na nagrobkach żydowskich w Polsce w XIII-XX wieku, „Kwartalnik Historii Kultury Materialnej” 66 (2018), nr 4.

Trzciński Andrzej, Sobota Jerzy, Cmentarze żydowskie w Międzyrzecu Podlaskim, Lublin 2009.

Unterman Alan, Encyklopedia tradycji i legend żydowskich, tłum. Olga Zienkiewicz, Warszawa 1994.

Vega Louis Alvares, Het Beth Haim van Ouderkerk: Beelden van een Portugees-Joodse begraafplaats, Assen 1979.

Vilenkin Esther, Rebbetzin Chana and the Three Mitzvahs of Her Name, Chabad. org, https:/www.chabad.org/theJewishWoman/article_cdo/aid/2917480/ jewish/Rebbetzin-Chana-and-the-Three-Mitzvahs-of-Her-Name.htm [dostęp: 12 kwietnia 2021].

Weres Estera, U źródeł kobiecej literatury żydowskiej-Rebeka z Tykocina i jej „Meneket Rywka”, „Bibliotekarz Podlaski” 16 (2015), nr 1.

Wischnitzer-Bernstein Rachel, Symbole und Gestalten der jüdischen Kunst, Berlin 1935.

Żebrowski Rafał, Źródło (studnia) Miriam, [w:] Polski słownik judaistyczny. Dzieje, kultura, religia, ludzie, red. Zofia Borzymińska, Rafał Żebrowski, Warszawa 2003, t. 2.

Andrzej Trzcinski

UMCS w Lublinie

atrzcinsk@poczta.onet.pl 